University of Rhode Island

DigitalCommons@URI

Open Access Master's Theses

1992

\title{
Mill Preservation in the Blackstone River Valley
}

George Daniel Meservey III

University of Rhode Island

Follow this and additional works at: https://digitalcommons.uri.edu/theses

\section{Recommended Citation}

Meservey, George Daniel III, "Mill Preservation in the Blackstone River Valley" (1992). Open Access

Master's Theses. Paper 744.

https://digitalcommons.uri.edu/theses/744

This Thesis is brought to you for free and open access by DigitalCommons@URI. It has been accepted for inclusion in Open Access Master's Theses by an authorized administrator of DigitalCommons@URI. For more information, please contact digitalcommons-group@uri.edu. 
MILL PRESERVATION IN THE BLACKSTONE RIVER VALLEY

BY

GEORGE DANIEL MESERVEY III

A RESEARCH PROJECT SUBMITTED IN

PARTIAL FULFILLMENT OF THE REQUIREMENTS

FOR THE DEGREE OF MASTER OF COMMUNITY PLANNING

The University of Rhode Island 1992 


\section{MASTER OF COMMUNITY PLANNING \\ RESEARCH PROJECT \\ OF \\ GEORGE DANIEL MESERVEY III}

Approved:

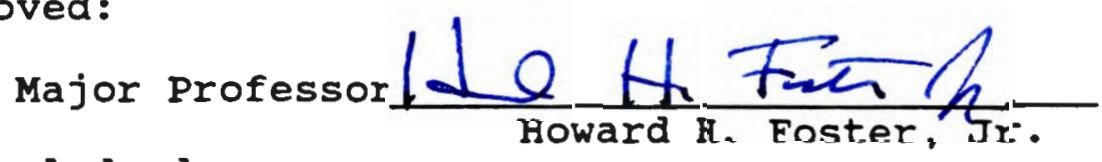

Acknowledged:

Director

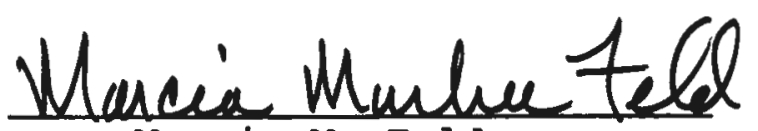

Marcia M. Feld 


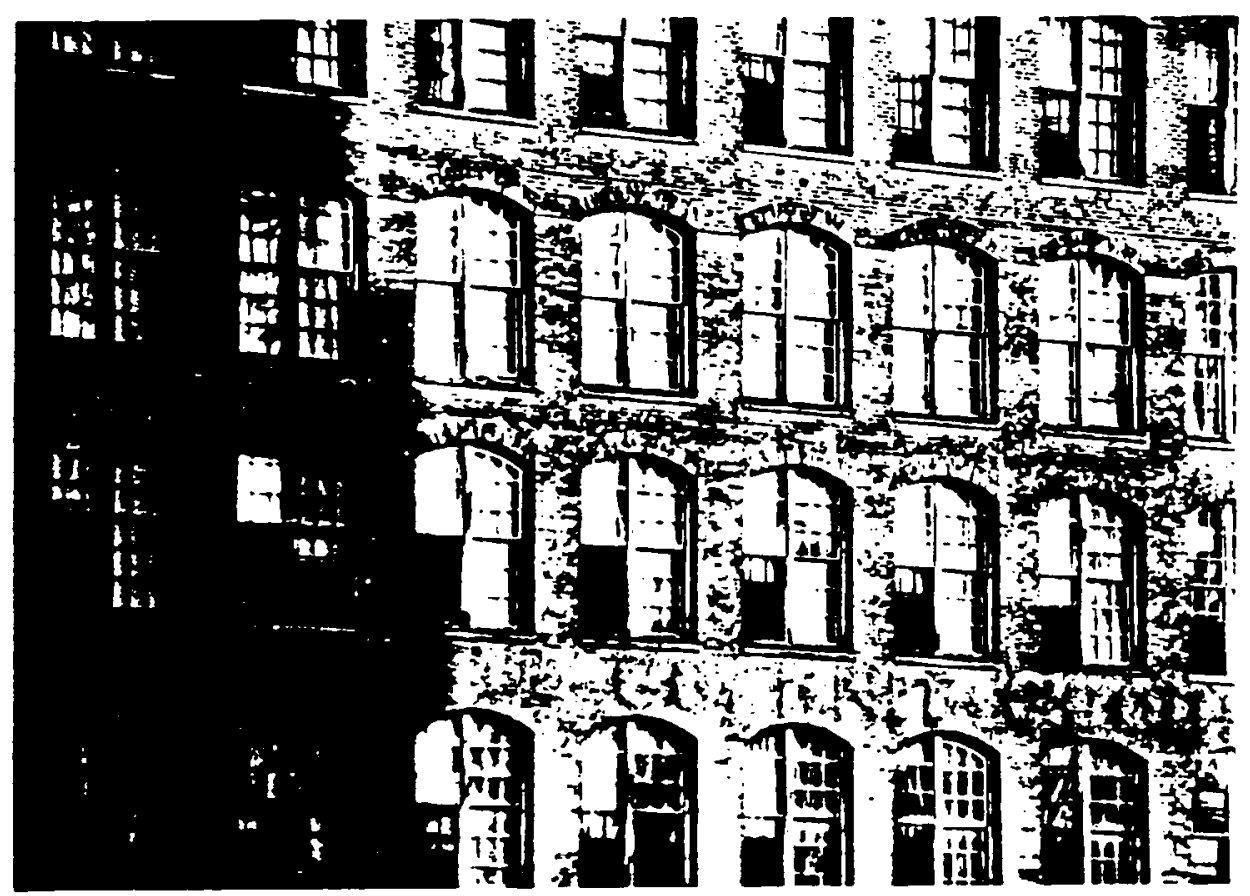




\section{ABSTRACT}

This document describes a project which evaluated industrial mills along the Blackstone River in Rhode Island, built between 1793 and 1910, in order to prioritize their potential for renovation/ reuse. Scores of textile mills built before 1910 still exist in the Blackstone River Valley. Some have been retro-fitted for contemporary use. Many are vacant and not maintained. Structures were evaluated based on their historical and cultural significance and the physical condition of the existing structure. Findings also include sections on the problems associated with mill reuse and some common adaptive reuse options. Some of the successful mill-renovation projects may serve as models for future action. 


\section{ACRNOWLEDGEMENTS}

The author wishes to express his appreciation to Dr. Howard H. Foster, Jr., Associate Professor, Community Planning and Area Development, for his guidance in researching and organizing this project. Thanks also to Dr. Farhad Atash, Community Planning, and Peter Coffin, Blackstone Valley National Heritage corridor, for their input on particular segments of the research. sincere gratitude must also be accorded my wife, cheryl, for her love and support during my enrollment at the University of Rhode Island. 


\section{TABLE OF CONTENTB}

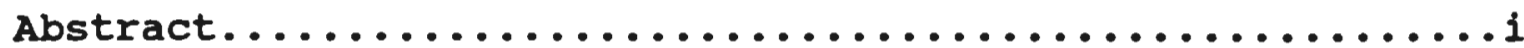

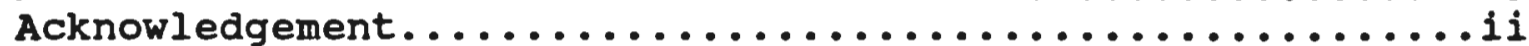

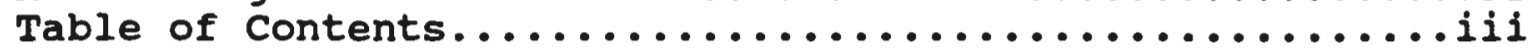

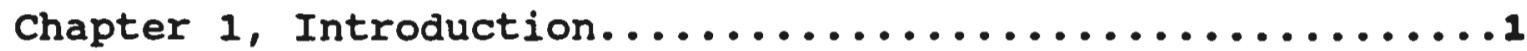

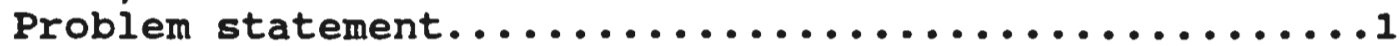

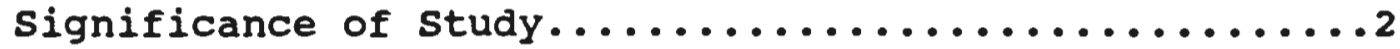

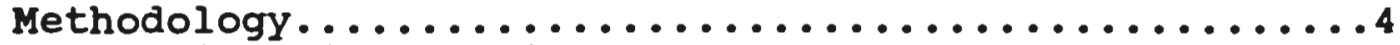

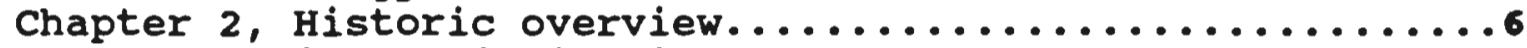

Early industrialization.................... 6

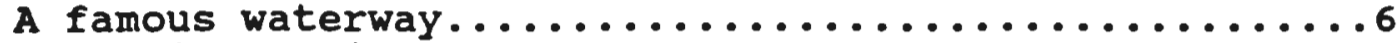

Economic decline..........................

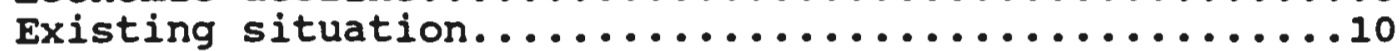

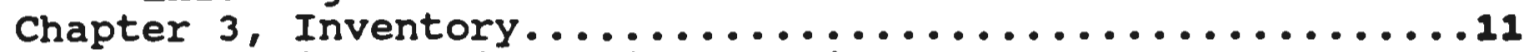

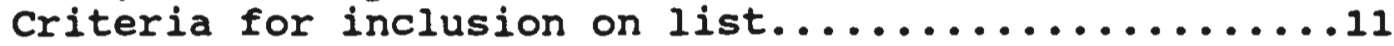

Description of specific features...............12

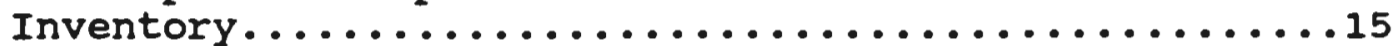

Chapter 4, Evaluation........................46

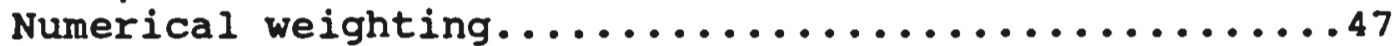

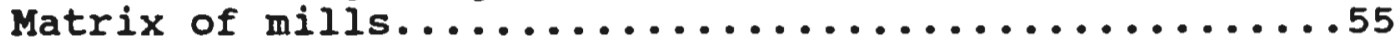

Listing of mills by relative value.............57

Findings of matrix........................ 58

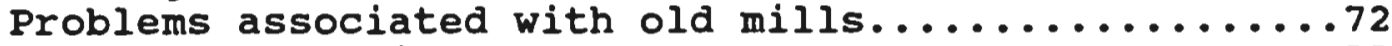

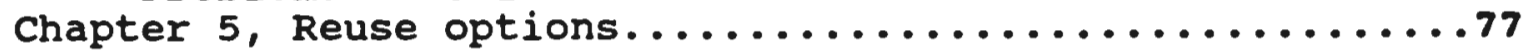

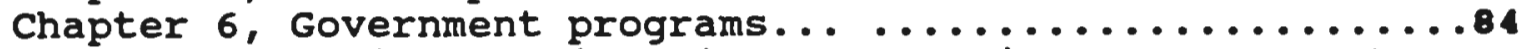

Federal aid for historic preservation............84

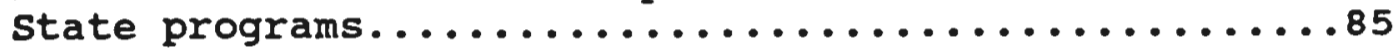

Local programs.......................... 86

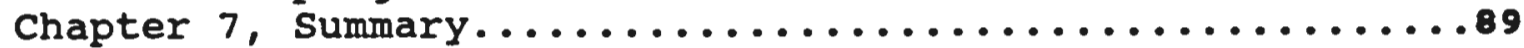

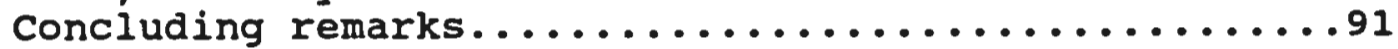

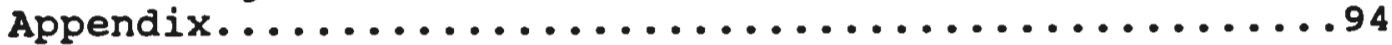

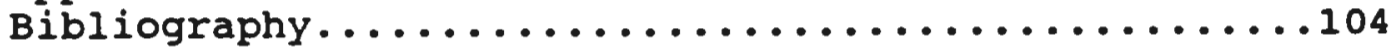




\section{CHAPTER 1, INTRODDCTION}

\section{Problem 8tatement}

The Blackstone River Valley, extending from worcester, Massachusetts to Providence, Rhode Island, has recently received designation as a National Heritage Corridor. Situated within this Blackstone River National Heritage Corridor are a number of mill structures. Some mills date back over 150 years. The mills are an artifact symbolizing the cultural and historic significance of the area. They were the focal point of the region's industrial growth. As such they should be catalogued and evaluated to determine existing physical condition and prospects for renovation/ restoration.

Federal designation of the area raises the possibility of communities obtaining matching grants and other federal aid to help bear the cost of preserving historic architecture and culture in the Blackstone valley. The Blackstone Valley Heritage Corridor Commission also serves to coordinate actions between state, local, and private parties. Now is an ideal time to evaluate local mills as a cultural resource. A plan for renovation and reuse is necessary to prevent further degradation of the resource. The subject of this project is the reuse potential of selected textile mills along the Blackstone River in Rhode Island. 


\section{significance of the subject}

Mill buildings and landscapes from the Industrial Revolution are a less popular element of our regional heritage than historic sites related to the American Revolution. Mills from the colonial period are acknowledged as historically significant, and many, such as the slater Mill in Pawtucket, Rhode Island, have been restored and protected. This distinction is not always accorded to mills built and used in the late 19th and early 20 th centuries. Many are treated as nothing more than outdated buildings. When their users leave they are left to ruin. Several mills in the Blackstone Valley fall into this category.

The overall dimension of many mill structures make them significant to industrial history. Structures built for use in the textile industry often contained single-room floor areas of over 50,000 square feet. ${ }^{1}$ when one considers the materials used in construction - stone, brick, and wood the mills are revealed as technological marvels of 19 th century building construction.

The machinery used to harness water power is equally grand and unique. The buildings were engineered to withstand the torque produced by huge water-driven drive belts. Compared to contemporary industrial facilities built of sheet metal and concrete, mills found along the

1 Blackstone Mill, for example, has three floors which each enclose a floor area of 58,890 square feet. 
Blackstone reflect the ingenuity and labor intensive nature of late 19th century American industrialization.

Architecturally, the mills reflect the predominant styles of the period. Though not elaborate as a rule, many mills were built in the victorian era and exhibit those architectural characteristics. Some used a Gothic motif and at least one mill has Romanesque architecture ${ }^{2}$. significant architecture is one of the criteria used by the National Register of Historic Places to determine inclusion on its listing.

The historic value of the mill era should not be underestimated. The Industrial Revolution was stimulated to a great extent by the innovations of factory manufacturing. Water power made the river the focal point of production. The Blackstone River was one of the most heavily worked rivers in the world at its peak in the late 19th century. ${ }^{3}$ The impact of industrialization on the society was profound, forever changing worklife in the valley.

The Blackstone River Valley is now an economically depressed area. The valley, along with most of its mill towns, has not fully recovered from the decline of the textile industry in New England. Any economic revitalization initiative should use existing resources as

2 Berkeley Mill in Cumberland (1872).

3 U.S. National Park Service. Blackstone River Corridor Study: Conservation Options. P. 18. 
part of its development strategy. Mill structures are an important resource which can be reused in a variety of applications, including retail space, moderate-income housing, and recreation.

\section{Methodology}

The task of determining the relative renovation potential of Blackstone Mills involved a number of distinct processes. The entire method is described below to inform the reader of the breadth and limitations of the study. The project began by defining the study area. Blackstone Valley National Heritage Corridor is spread over two states from Worcester to Providence. Initial data collection showed that the project needed to be reduced to a manageable size. It was decided that the author would focus only on mills in the Rhode Island section of the corridor. Since many mills in urban sections of the corridor had little connection to the Blackstone River, only mills which abut the River or used water power were included in the study. Two mill sites on the Branch River, a major tributary, were added to the listing because of their historic value and future economic potential.

An inventory of all mills was then prepared. For the sake of comprehensiveness, a variety of secondary sources were utilized to develop the initial list. The author then visited each site to observe its physical and cultural attributes. Findings were recorded and the mills were 
organized in descending order by geographic location, north to south.

To prioritize the list, a set of evaluation criteria was developed. The criteria were drawn from those used by other historic preservation efforts, and tailored to the needs of this study. Each mill was given a weighted score according to its relative value. Results of the evaluation process were set in a matrix which was used to determine the mills with the highest renovation/reuse potential. Further exploration of the elements of successful industrial facility reuse was conducted through primary data collection and research. This section of the project attempted to define a system by which the reuse process could be started with unrestored mills. The outcome of this project is not a comprehensive guide to mill preservation and reuse. It was intended to create a prioritized listing of historic mill structures on the Blackstone River. Future action requires individual study of each mill's attributes and potentials, and joint effort by property owners and local officials in determining the mill's best use. 


\section{CHAPTER 2, HIBTORIC OVERVIEW}

\section{Early Industrialization}

The Blackstone River Valley is rich in history and Early American culture. It is significant to our nation's Industrial Revolution, as well as to regional development. Beginning with the slater mills of the early nineteenth century, water powered textile mills were the driving force behind the region's development for more than a century. To understand the impact of the mills and mill towns, it is necessary to have a brief understanding of the history of water use on the Blackstone.

Before the arrival of industry, the Blackstone valley was dotted with farms and a few small settlements. In 1793, Samuel slater built a cotton spinning mill in Pawtucket. The success of slater's mill marked the beginning of a period of unheralded growth for the region. Within a generation, scores of water-powered mills were built along the Blackstone River. Slater's mill stands today as the oldest textile mill in North America.4

The Blackstone: A famous industrial waterway

The Blackstone River became a popular site for industry for a number of reasons. First and foremost were the river's physical characteristics. The river has a drop of ten feet per mile, making it one of fastest drops on the

${ }^{4}$ Doug Reynolds and Marjory Meyers. Working in the Blackstone River Valley, Blackstone River National Heritage Corridor Commission. P. vii. 
continent. The river's average slope is steeper than the Colorado River as it passes through the Grand Canyon. 5 The river's steepness, coupled with a number of convenient falls, made it ideal for harnessing water power. Location of the market was another factor in the rise of the Blackstone as an industrial focal point. The Blackstone River runs between Worcester and Providence, two major cities of the era. Boston is less than fifty miles away. Since, transportation was a limiting factor to profitable production in the 19th century, goods manufactured along on the Blackstone River were already relatively close to the market. Even New York could be reached by ship in reasonable time. The Blackstone Canal (1828) and the Providence and worcester Railroad (1848) further aided transportation in the region.

European immigration in the 19th century maintained an abundant supply of low-priced labor in the valley. Immigrants came to the valley looking for jobs, and were willing to work for low wages. Census records show that the number of immigrants to the Blackstone region were more than enough to meet demand. ${ }^{6}$ This kept the price of labor low,

${ }^{5}$ Blackstone River Canoe Guide. Blackstone River Valley National Heritage Corridor Commission.

${ }^{6} \mathrm{Jeanne} \mathrm{H}$. Armstrong et al."Industrial planning in the Blackstone Valley: Does the Past Equal the Future?" in Douglas Reynolds and Marjory Meyers, eds., working in the Blackstone River Valley: Exploring the Heritage of Industrialization, Reynolds and Meyers, Eds. 1991. Woonsocket: Sheehan Printing, p.19. 
attracting investment to the region.

The financial resources needed to start large-scale mills became readily available by the 1840's. Periodic bank crises inhibited growth for short periods, but government policies made entry into the textile industry fairly easy. 7

The earliest textile mill in North America was the slater Mill in Pawtucket. While slater's first mill employed only thirty people ${ }^{8}$, it opened the door to rapid expansion. The resources described above made it possible for industry in the Blackstone valley to increase quickly. By 1844, ninety-four mills lined the banks of the Blackstone River and its tributaries. 9

Economic Decline

The textile industry in New England thrived into the early 20th century. A number of factors facilitated its demise. Many of the reasons for the growth of the industry

${ }^{7}$ Lance E. Davis,"Sources of Industrial Finance: The American Industry, a Case Study" "Exploration of Entrepreneurial History, vol. IX, no. 4, Quoted in Douglas Reynolds and Marjory Meyers, eds., "Industrial Planning in the Blackstone Valley: Does the Past Equal the Future?" in Working in the Blackstone River Valley: Exploring the Heritage of Industrialization, 1991. Woonsocket: Sheehan Printing.

${ }^{8}$ Steve Dunwell, The Run of the Mill, in United States National Park Service. 1985. Blackstone River Corridor Study: Conservation options, Draft. Washington, DC: U.S. Government Printing office.

${ }^{9}$ Jeanne H. Armstrong et al."Industrial Planning in the Blackstone Valley: Does the Past Equal the Future?" in Douglas Reynolds and Marjory Meyers, eds., Working in the Blackstone River Valley: Exploring the Heritage of Industrialization, Reynolds and Meyers, Eds. 1991. Woonsocket: Sheehan Printing, p.15. 
undermined its continued prosperity in the region. At the turn of the century, the mills' energy sources, the location of the population, and the New England labor pool no longer favored the Blackstone Valley as an industrial center.

The change from water power to steam was desirable for factory production. The whims of nature, droughts in summer and freezes in winter, would no longer dictate plant outputs. But the use of steam engines removed the advantage the Blackstone mills had enjoyed when water power was the only option. Factories no longer had to be located near a river.

Demographic changes in the United States also conspired against New England textile mills. The population center had been in the Northeast, but was shifting to the South and West. The point of production was no longer close to the market, and this hurt the industry.

The supply of labor remained adequate to meet the demand for mill workers, but workers attempts to raise wages and working conditions made the factories less profitable. After 1890, a trend toward industrial flight to the South took hold and increased. Plant layouts were radically changed in the 1920's to increase production. A "deskilling" of the labor force combined with a loss of many jobs to automation, made mill work less desirable, and it was seldom the first choice of those who had employment options. 
The factors listed above led to deindustrialization of the Blackstone Valley. After the Great Depression, many mills were abandoned, few maintained. of the ninety-four mills recorded in 1844 , many have been lost to fire, decay, or urban renewal. The heritage value of the mill era must be preserved while remaining structures still stand as a record of this nation's industrial heritage.

Existing 8ituation

Much of the Blackstone valley remains in an economically depressed condition. Between 1969 and 1980, the Massachusetts portion of the valley lost 33 percent of its manufacturing jobs. The Rhode Island segment has experienced a comparable loss. Measures are needed to revitalize the region economically. Population growth has stabilized after a rapid decline associated with the mills' demise. It is hoped that new approaches to economic development will help the area reestablish a niche in the regional economy. 
CHAPTER 3, INVENTORY

Criteria

For the purposes of this project, only mills in the Rhode Island Section of the Corridor will be evaluated. There is variation in state statutes and policies regarding historic preservation and economic development between Massachusetts and Rhode Island. A strategy including mills in both states is outside the scope of the project. Also, the majority of mills in the corridor are located in the Rhode Island section.

Mills to be included in this study must meet four criteria:

1. Used for textile manufacture

2. Property abuts the Blackstone River

3. The mill was built before 1910 .

4. The physical structure remains intact at time of study

The first step in evaluating mills along the Blackstone is to inventory existing structures. Much of the inventory work has already been completed by other agencies, so this element will focus on acquiring secondary information. Sources for data are the Rhode Island Historic Preservation society, Blackstone Valley National Heritage Corridor Commission, Historic American Engineering Record, and other historic inventories of the region.

To narrow the scope of the project, only mills which have river frontage or used water power as an energy source will be evaluated. 


\section{Description of specific Features}

The qualities which make a mill worth saving focus on historic, cultural, and architectural features. A description of the qualities to be used in evaluation in this study are listed below.

* Architecture - style and building materials give many mills an historic value which should be understood and preserved.

* Uniqueness of design or function - This would include the first use of a particular industrial method or an innovation which increased the output of the mill. The textile industry along the Blackstone River was famous for a number of processing inventions and its water harnessing methods.

* Size of structure - Large interior spaces may make a mill suitable for adapted recreational uses which require large areas. The cost to rebuild such spaces would be prohibitive in many of the small towns in which the mills are located. The Blackstone River Valley contains a number of mills which in their era were the largest of their kind. 10

* Age of structure - The definition of an "old mill" for this project is one which was constructed prior to 1910. * Location in community - The proximity of a mill to a

${ }^{10}$ Gary Kulik and Julia C. Bonham. Rhode Island: An Inventory of Historic Engineering and Industrial Sites, p. viii. 
central place may indicate the prospects for future use. Those mills which are near downtown areas may be transformed into commercial/ retail areas. Mills far from a central place could be more readily retrofitted for industrial use. Additionally, some mills are part of an integrated mill village, and thus have a higher value in the context of larger design.

* Condition of structure - This will be a simple grading of the appearance and superficial structural integrity of each mill on the listing. Subject mills will be classified as good, fair, or poor. ${ }^{11}$

* Current use of structure - If the mill is currently being used, renovation of historic components may be difficult.

* Feasibility of restoration - other factors such as ownership questions, on-site toxic materials, and opinions of local officials will be considered.

The above criteria were collected for each mill and organized into a table which assigns points to each mill for its rank in each category. Systems that assign numerical scores to surveyed historic resources for the purposes of establishing preservation priorities have been established

11 The criteria for evaluation will be similar to that used by winsor \& Associates for a 1990 Providence Housing Study. structures are rated by visual inspection. A classification of "good" means there are no noticeable improvements needed; "fair" requires minor repairs; "poor" means the structure is in need of major repairs. 
as viable methodology by the National Historic Register.12 This will make it possible to show the relative value of each mill.

In some cases, one or more criteria could not be fully utilized due to lack of data. However, the data collection portion of this study recorded 30 mills which matched the criteria. A couple of historic mills in the National Heritage corridor have been omitted because they were located a considerable distance from the Blackstone River. Most notable omissions are the Jenckes Mills in a residential area of Woonsocket. One Jenckes Mill houses a tire wholesaler while the other is dedicated to a variety of industrial and commercial uses.

The breakdown of mills by town is as follows:

$\begin{array}{lr}\text { North Smithfield } & 3 \\ \text { Woonsocket } & 12 \\ \text { Cumberland } & 3 \\ \text { Lincoln Falls } & 2 \\ \text { Central Fal } & 6 \\ \text { Pawtucket } & \frac{4}{30} \\ \text { Total } & \end{array}$

${ }^{12}$ National Register Bulletin. 1977. p.55. A much copied example of the use of a numerical evaluation system is the college Hill Demonstration study (Providence, 1967). 


\section{Inventory of Blackstone Valley Mills}

Mills are listed below in the order they appear on the river, proceeding north to south.

- Site observed and condition and use noted

North Smithfield

Forestdale (Stamina) Mill *

1860

Destroyed by fire in 1977; Dam, raceways, and foundation still intact; Declared superfund site because of TCE spill on property. Polytop Inc. now seeking to establish hydroplant using old dam and raceways.

North Smithfield

Slatersuille M1ll *

1826

Branch River

Use: Glas-Kraft manufacturing (defunct?)

Condition: Good

Comment: 6 structures; 5 industrial, 1 office.

Excellent location for commercial reuse; traffic pattern must be altered (historic bridge).

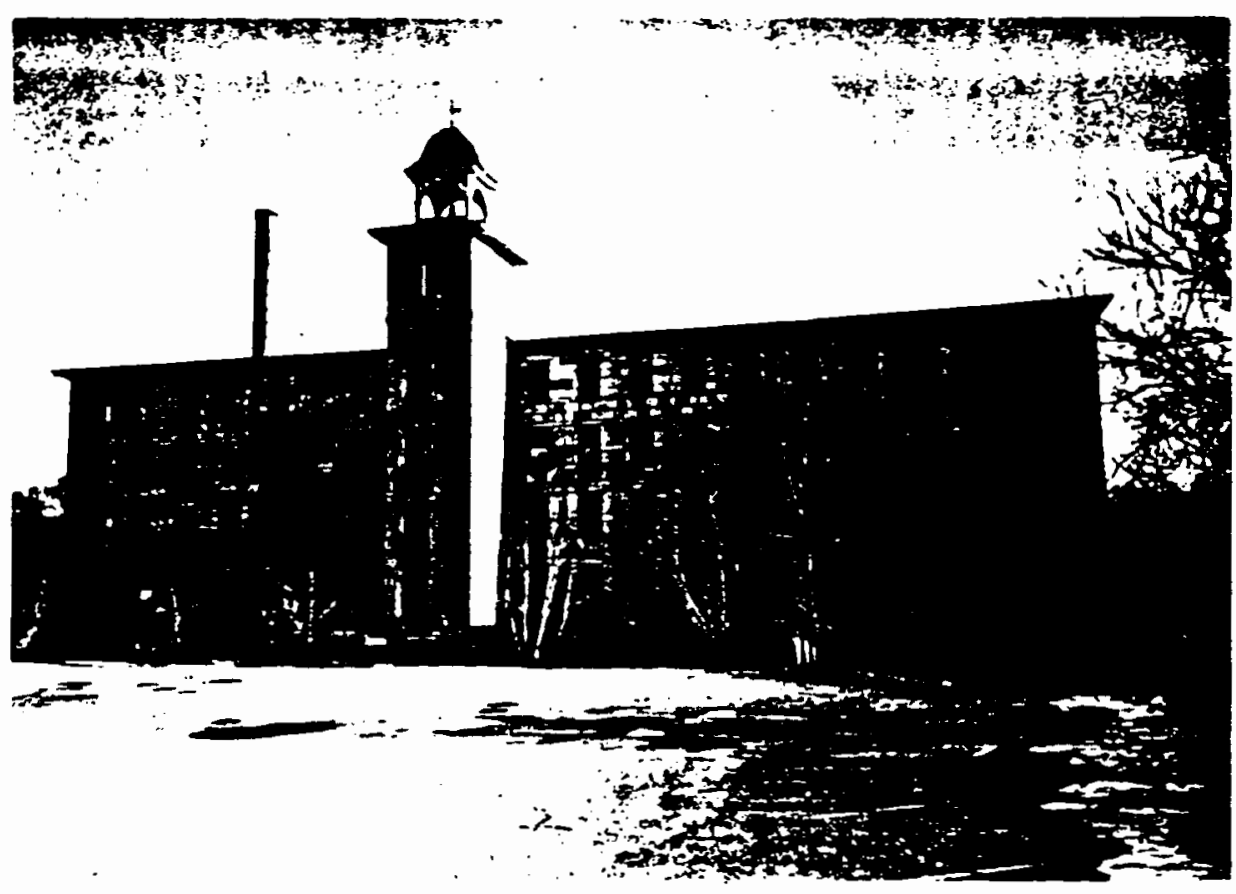

Slatersville $\mathrm{M} 111$ 
North Smithfield

Blackstone Mill 1904

Use: Variety of industrial tenants.

Condition: Good

Comment: Problems with economic viability come from tax burdens (property and local inventory tax), access for trucks to highway, zoning (N.S. recently granted an extension of the types of uses permitted in this mill). High cost of electricity in R.I. is a factor in trying to attract new tenants. No more than 308 of available space has been rented since 1988 (when Tupperware relocated).

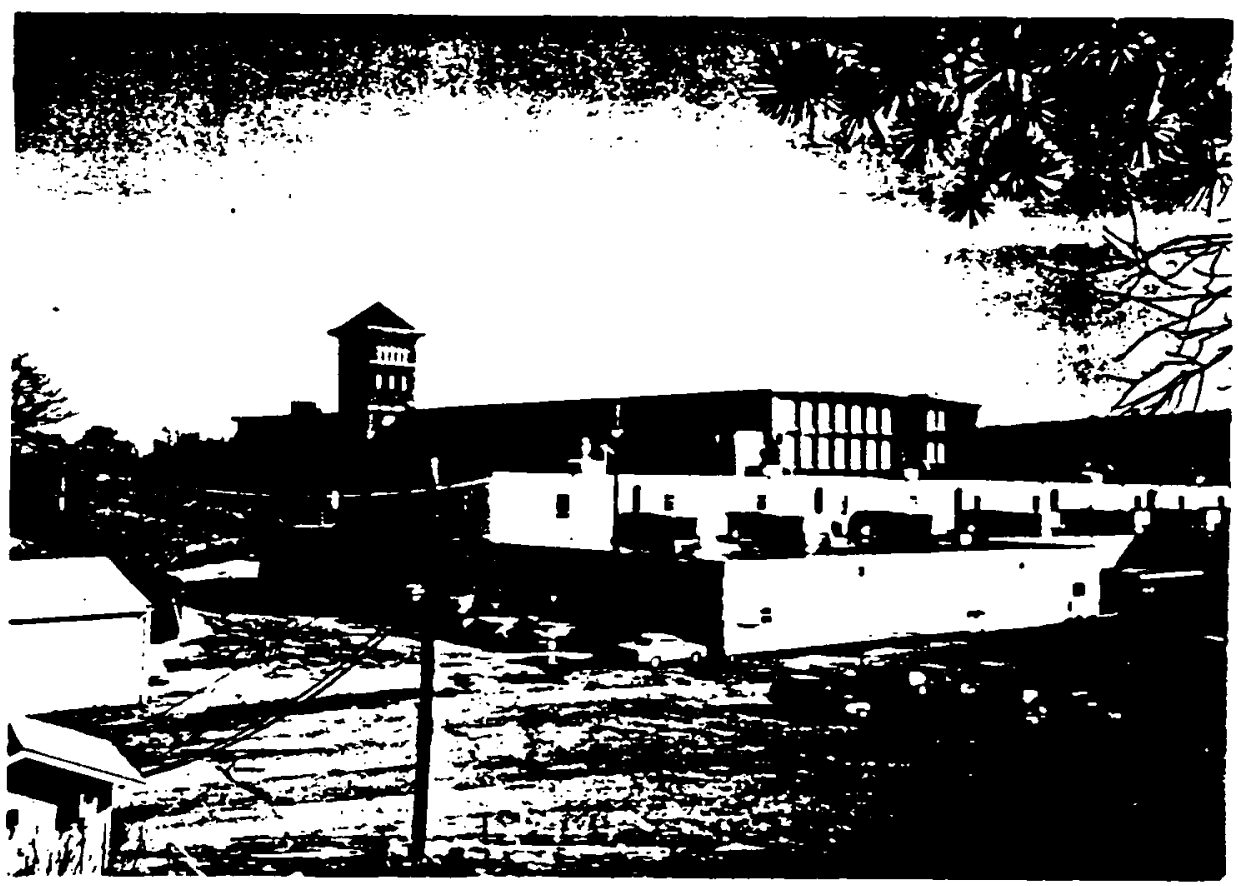

Blackstone Mill 
Woons ocket

Samoset and Nyanza Mills *

1911 and 1910

Use: Industrial

Condition: Good

Comment: 3 and 4 story flat-roofed, brick factories in the flood plain. Some of the last woolen mills built in the state. Nyanza has had some renovation in the form of window replacement, and still houses textile manufacture.

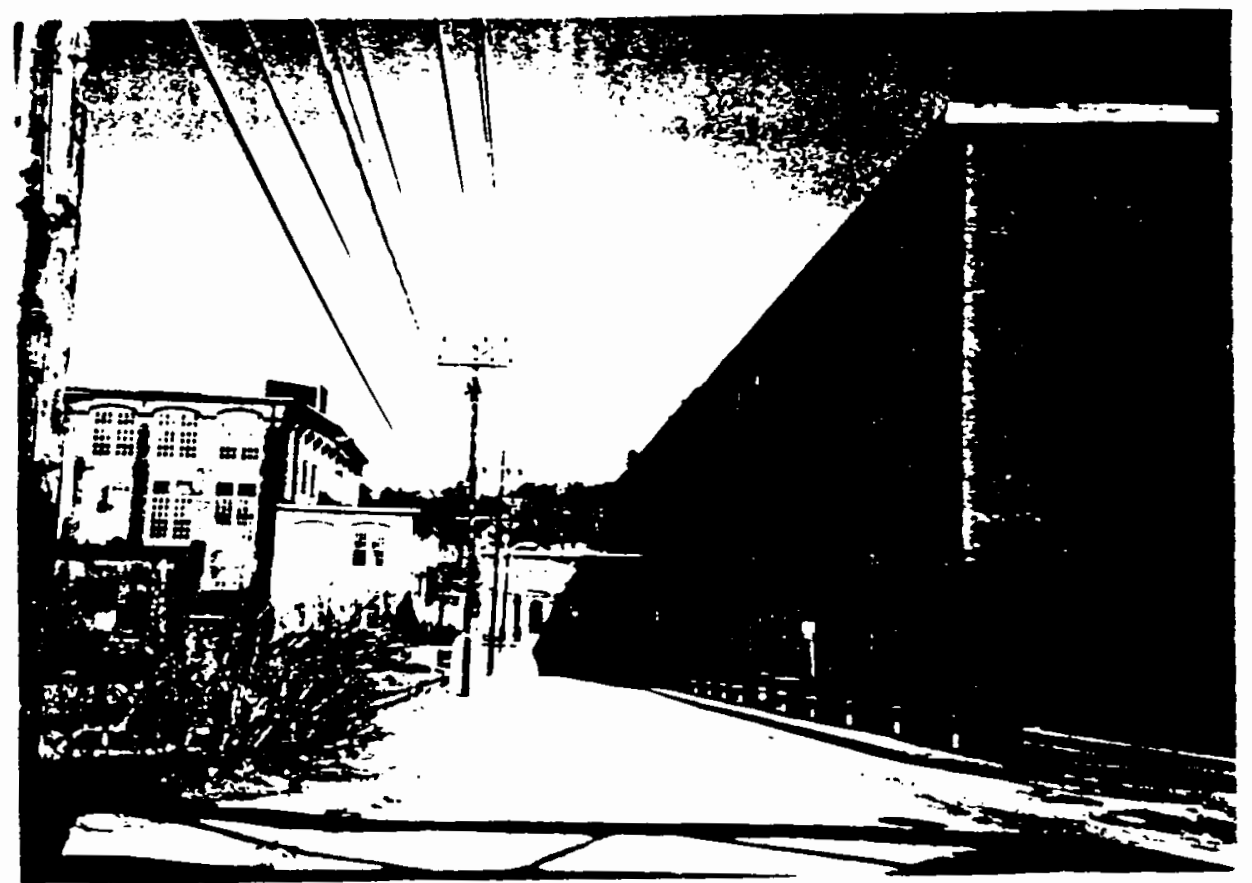

Samoset and Nyanza Mills 

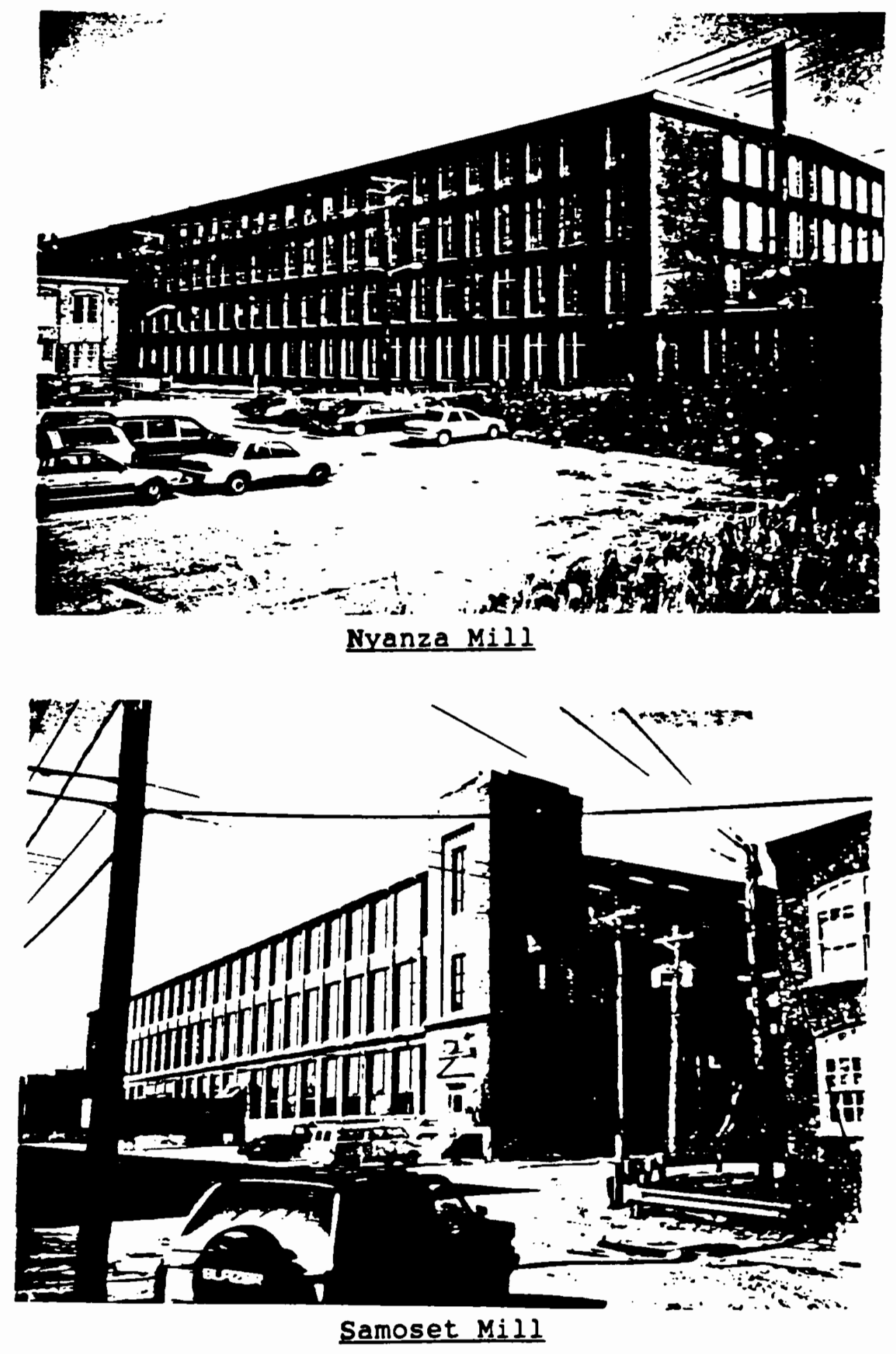
Woonsocket

Alice MIII *

1889

Use: Full capacity in industrial use

Condition: Excellent

Comment: Well maintained exterior, double tower design.

Original products: Rubberized fabric shoes and boots

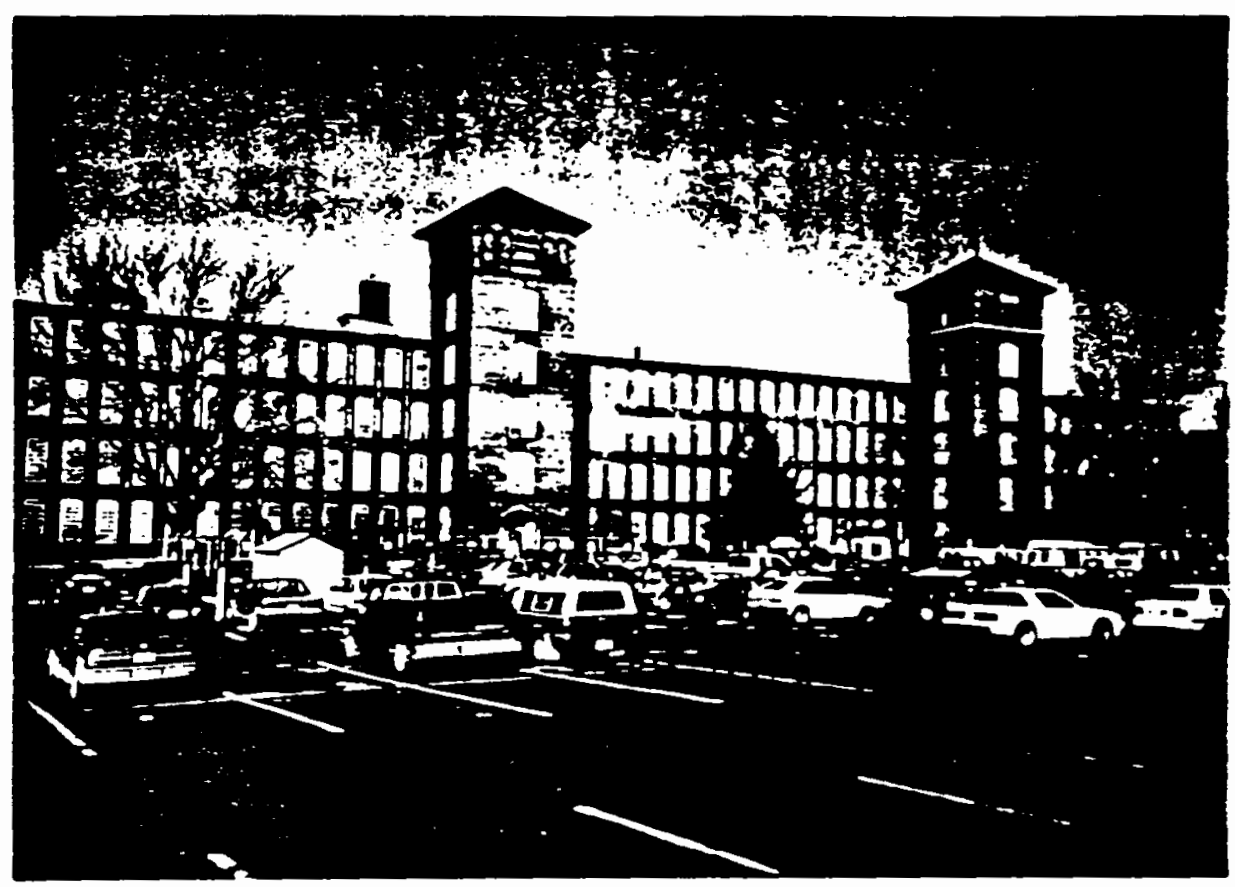

Allce Mill 
Woonsocket

Jules Desurmont Norsted Mill * 1907

Use: Industrial

Condition: Good

Comment: Large bullding in valley north of CBD. Should remain industrial due to location.

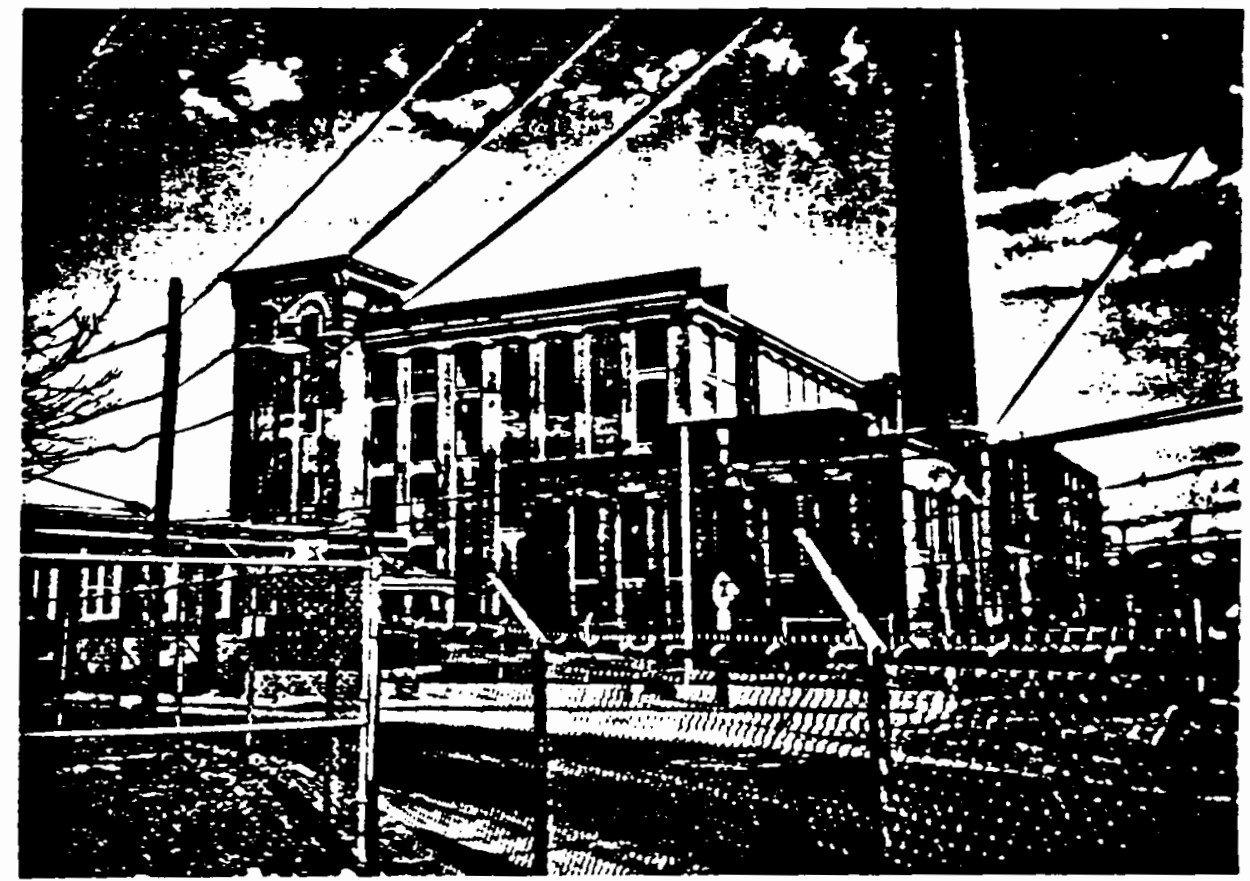

Jules Desurmont Mill 
Noónsocket

Glenark Mill *

1865

Use: Residential (apartments)

Condition: Excellent

Comment: Located immediately above falls. Fine example of adaptive reuse in a residential neighborhood.

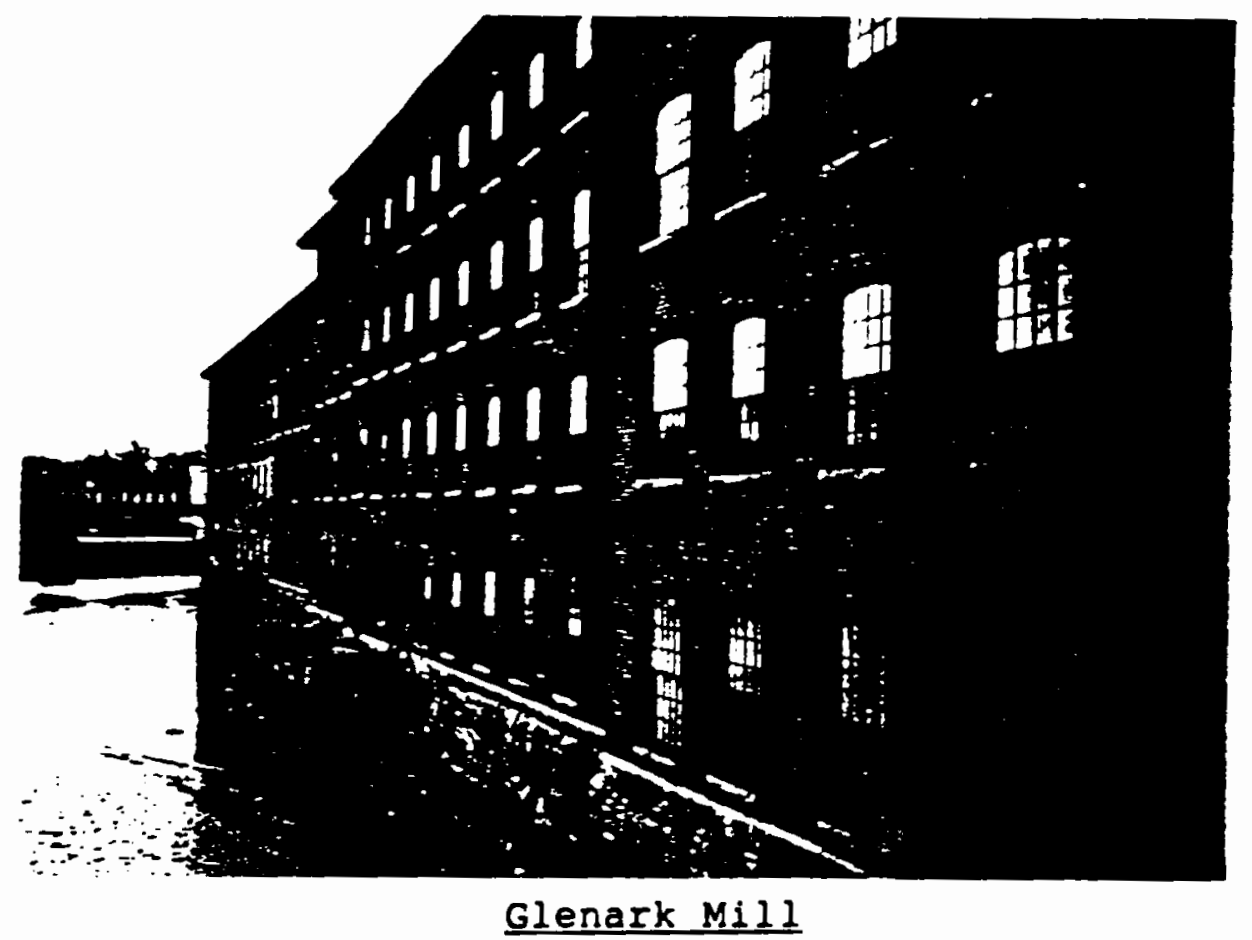


Woonsocket

Falls Yarn Mill *

1846

Use: Abandoned

Condition: Falr

Comment: Small single structure located on high traffic

Market Square. Proposed site for visitor center in

"Historic Blackstone Riverfront" Master Plan.

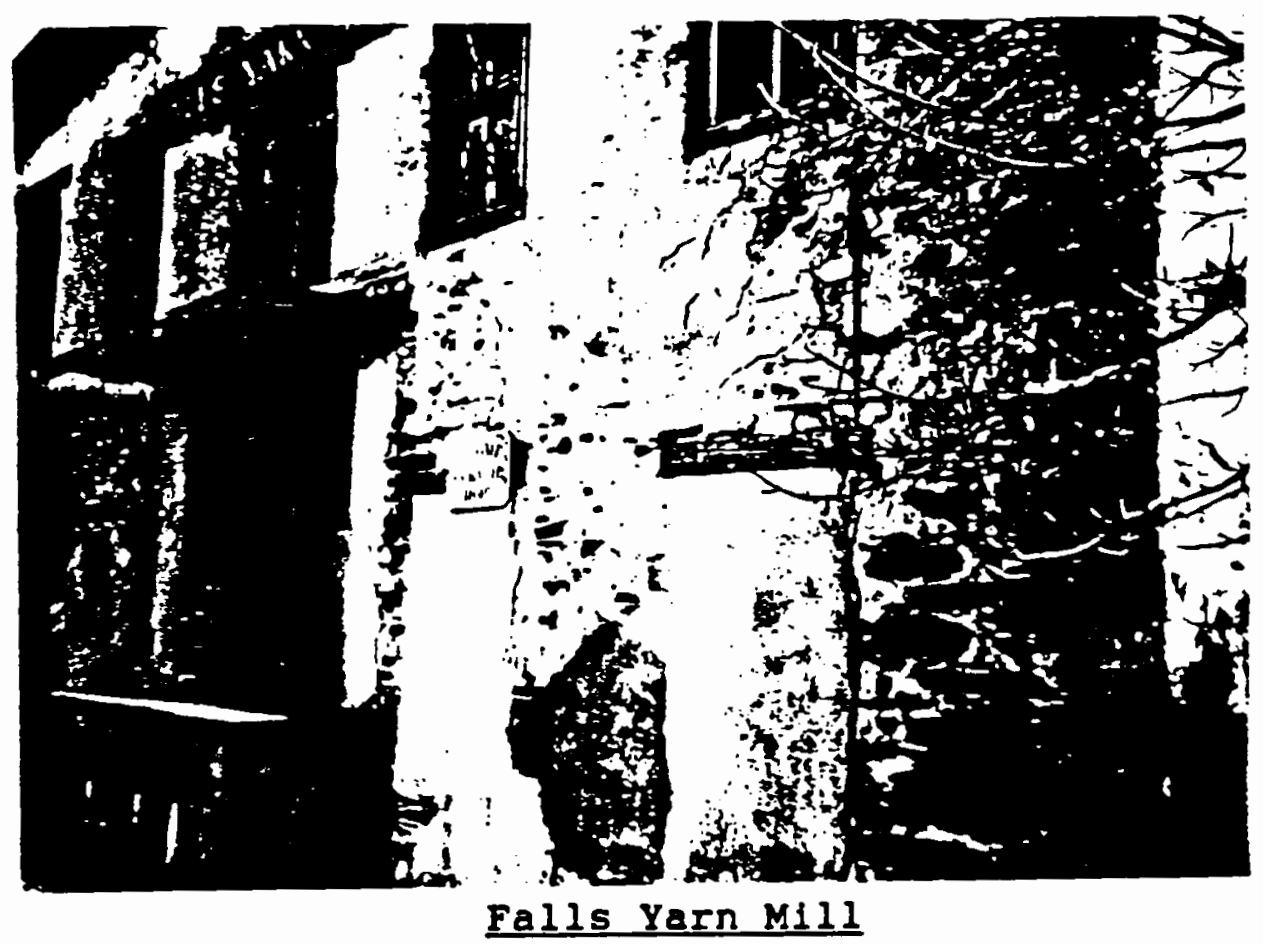




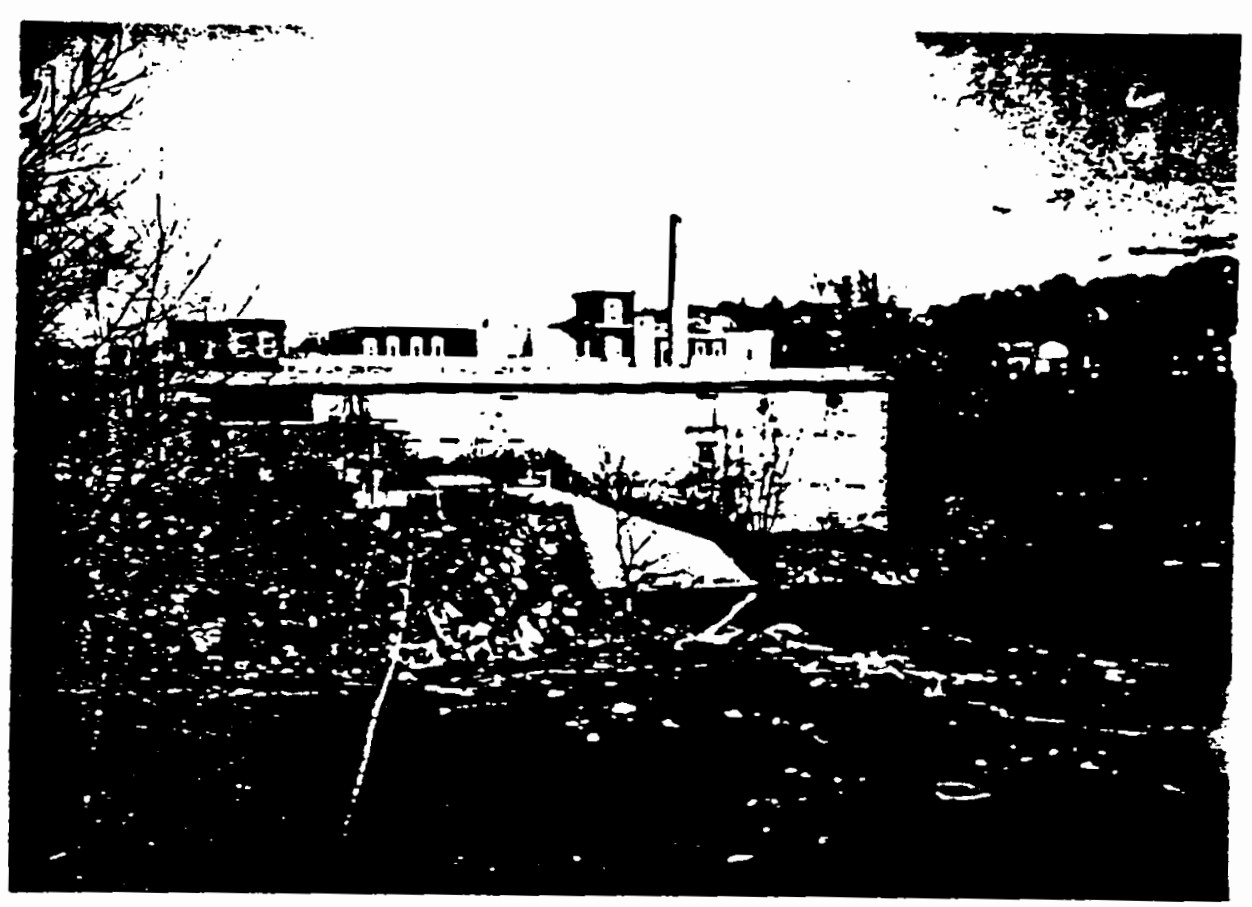

Fal1s Yarn $M 111$

(Proximity to River)

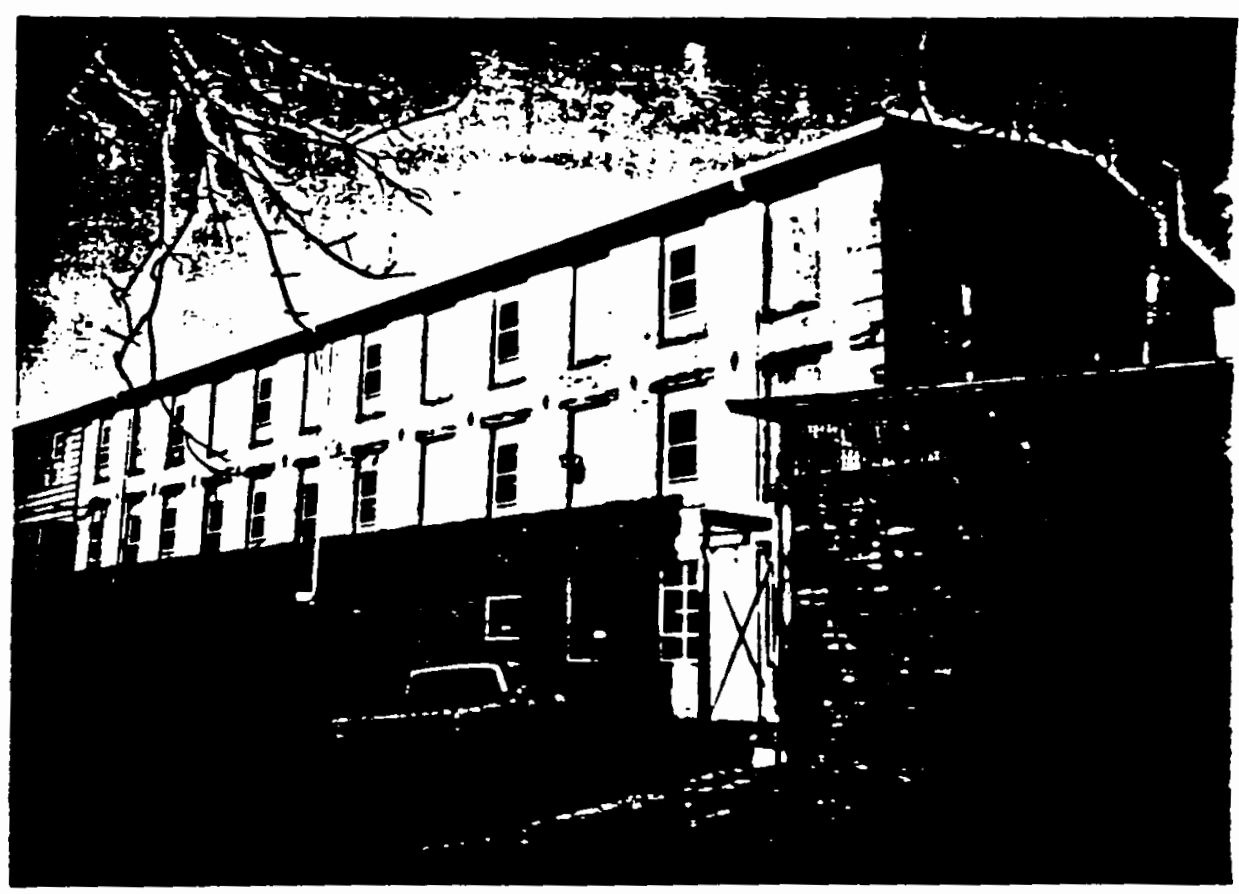

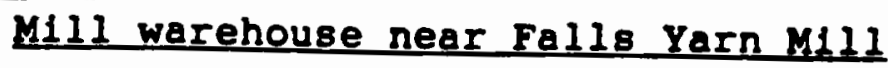




\section{Woonsocket}

Ballou/Lippitt Woolen Mill *

1836

Use: Industrial, partially renovated.

Condition: Fair to good

Comment: - Located on busy Main St., could have tremendous reuse potential. Bullt over part of Lyman Trench.

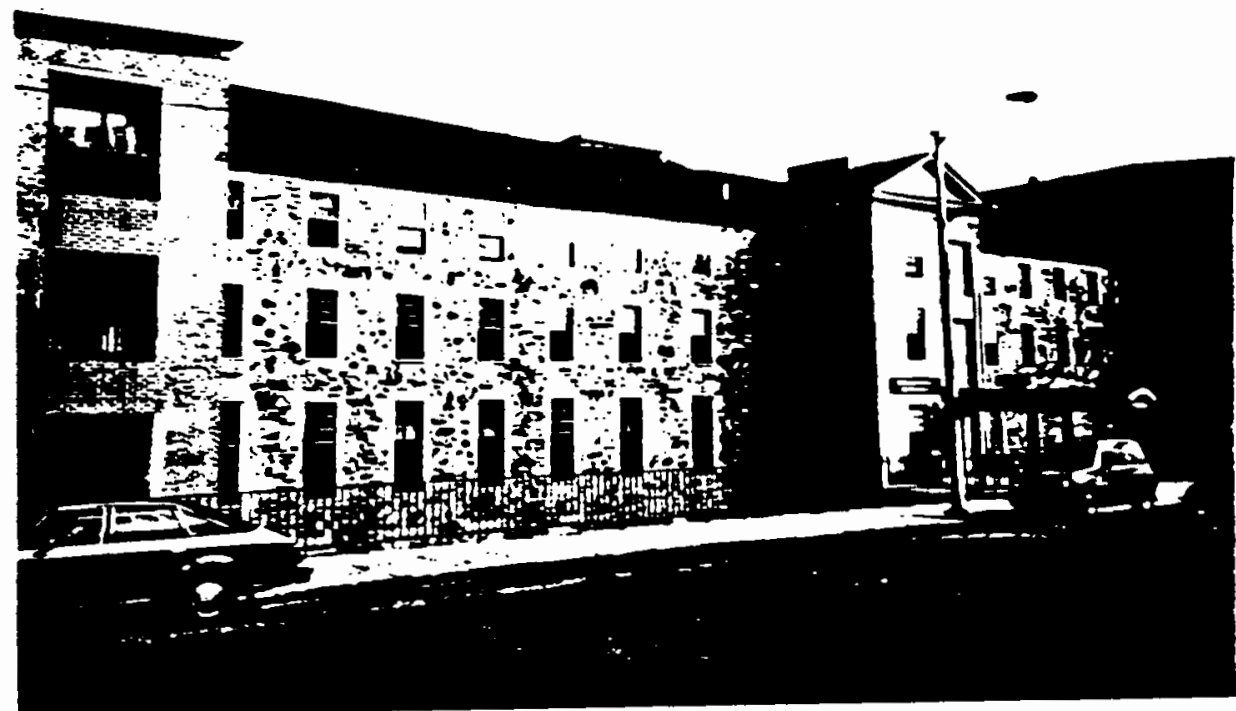

Ballou Lippitt Mill 
Woonsocket

Marris Mill Number 2 *

1840

Use: Industrial and commercial

Condition: Good

Comment: 1 structure, 5 stories, v18ible from the rear of Main St. site. A later commercial block (1897) was bullt onto the northwest corner.

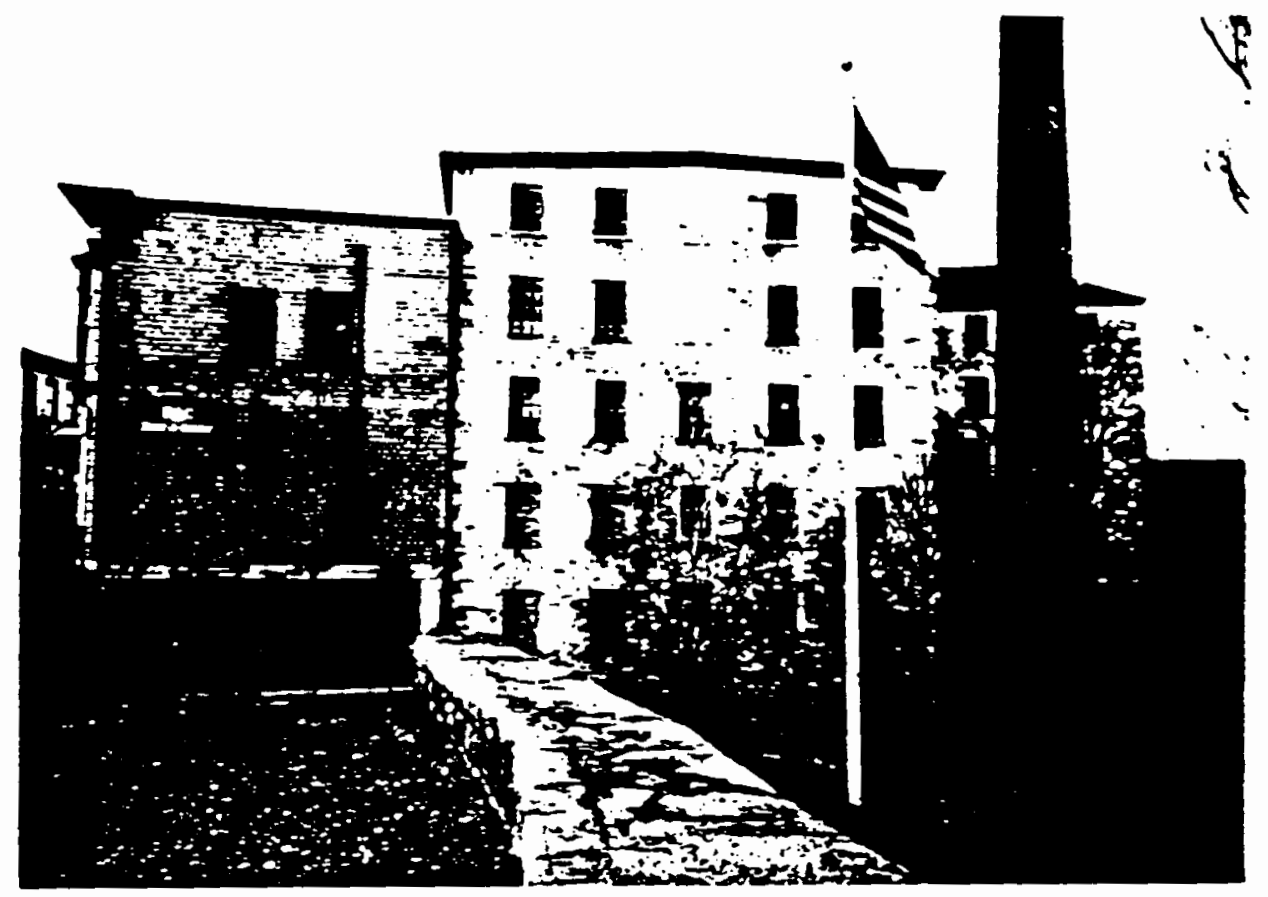

Harris Mill :2 
Woonsocket

Narragansett InItting MIIIs *

Early $1900 s$

Use: Industrial/text1les

Condition: Good

Comment: This section between the Bernon st. and court st. bridges on the north side of the river, is a collection of old milis formerly the sidney Worsted Company, the Novelty Knitting Company, the Bernon Wet/wash Laundry and the Lelcester Knitting M1ll( now Narragansett).

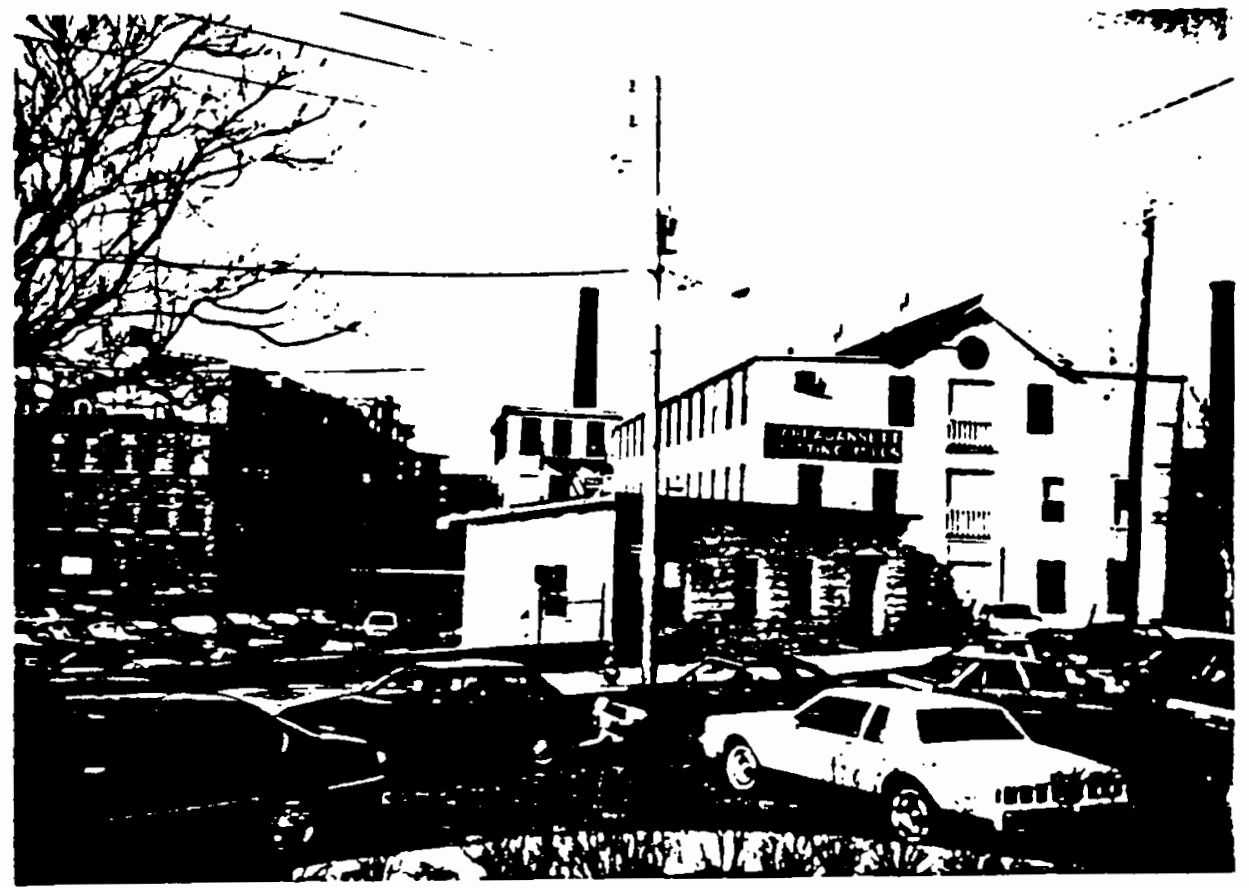

Narragansett Knltting Milis 
Noonsocket

Bernon M111s *

1827- 1859

Use: Moderate level of Industrial use. Buildings not fully utilized.

Condition: Good

Comment: Excellent downtown location, could be target of adaptive reuse for housing or retail. Beautiful fieldstone facade above river. Major historic and architectural significance.

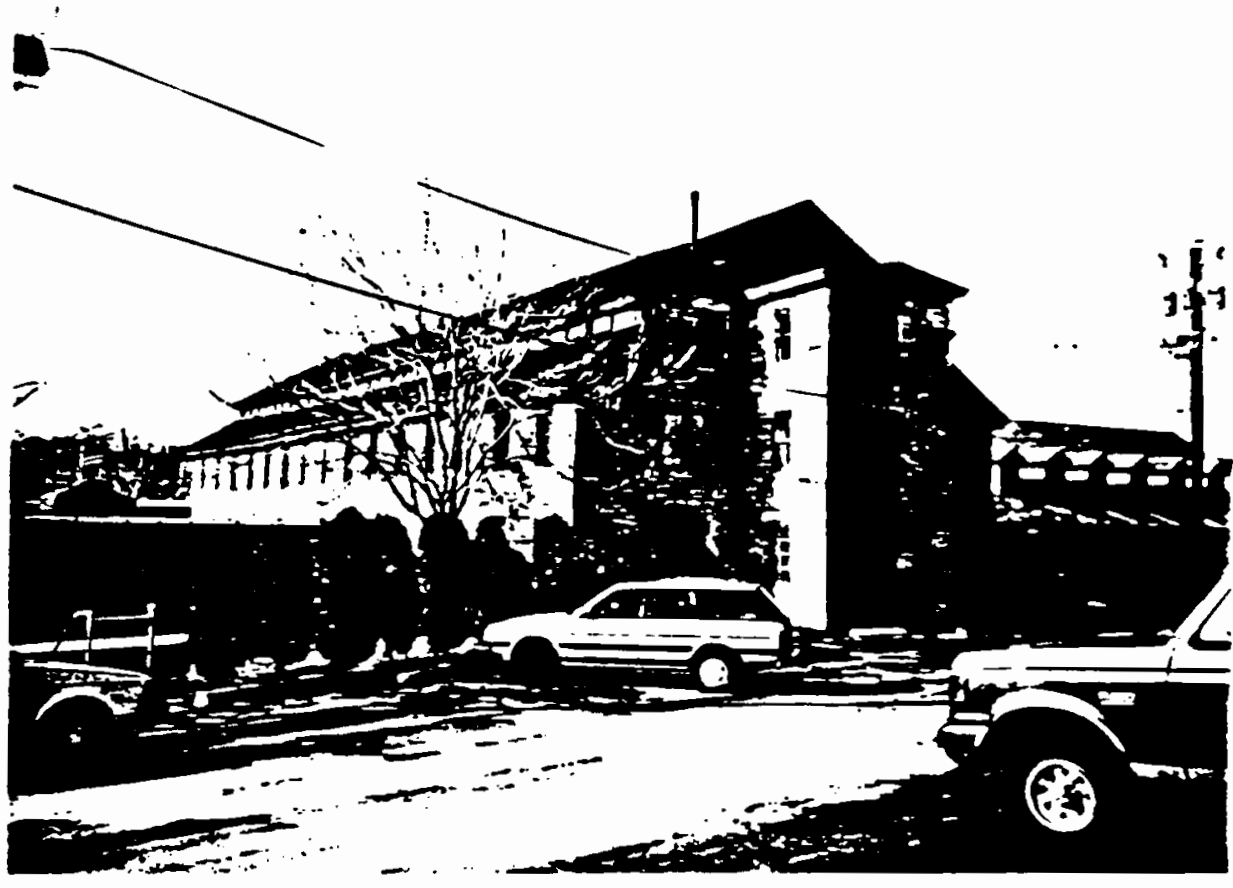

Bernon Mill 1 
Woonsocket

River Spinning Mill *

1894

Use: Industrlal (ACS Industries, makers of fllters, scouring pads, industrial wire mesh)

Condition: Good

Comment: North of Lafayette M1ll in a low trafflc area. Footbridge over Blackstone River across street. Octagonal chimney.

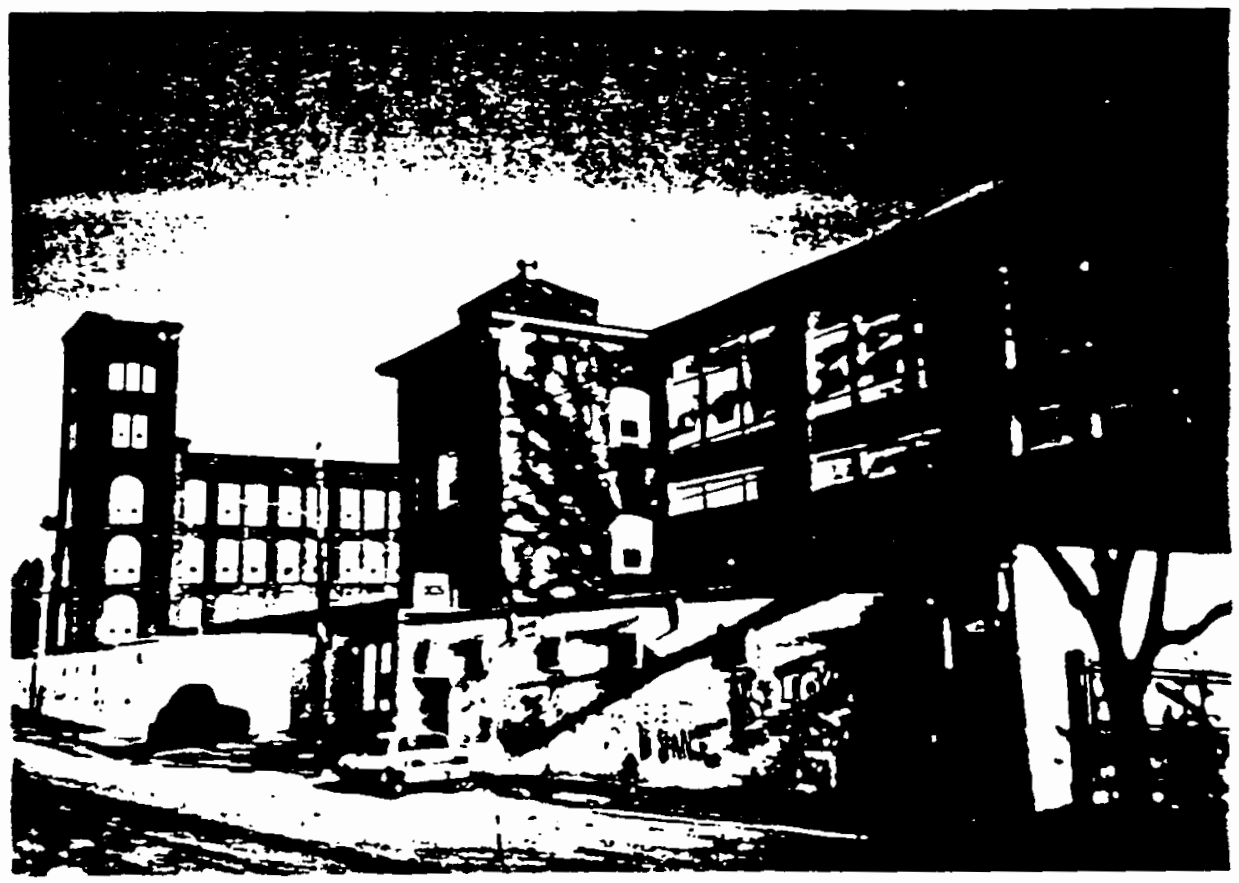

River Spinning Mill 
Woonsocket

Lafayette Worsted Company *

1889

Use: Industrial

Condition: Good

Comment: 6 total buildings; 4 large structures of 3-5

stories, 2 mansard-roofed office buildings. Designed by French mill engineer and owned by French industrialist as part of plan to better control French-Canadian work force.

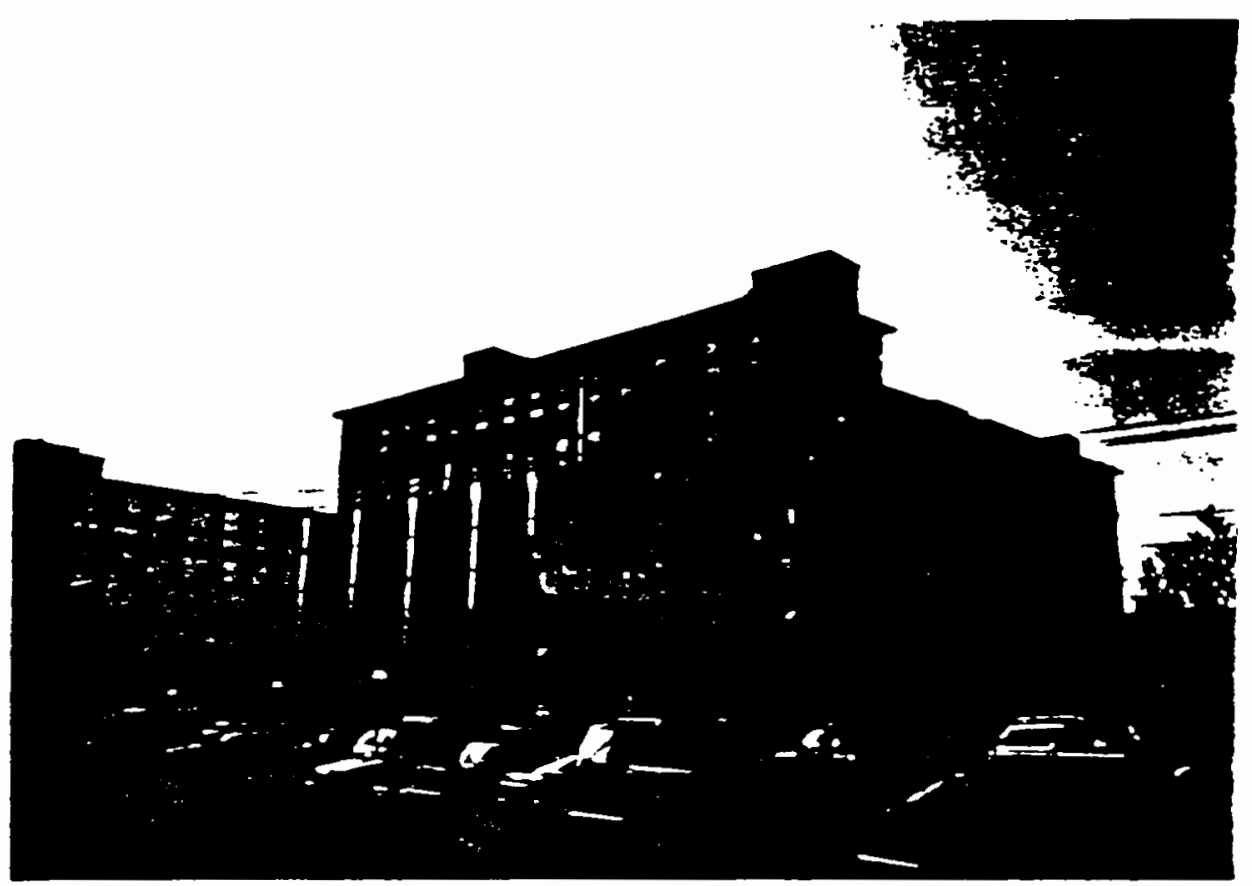

Lafayette Worsted Company 
Woonsocket

French Worsted Company *

1906-10

Use: Industrial, recreational

Condition: Good

Comment: Located south of Hamlet street, a busy road which separates French from Lafayette Mill. 2 5-story brick milis. An office on site has been converted into a restaurant (out of business) and a smaller structure is a family recreation center.

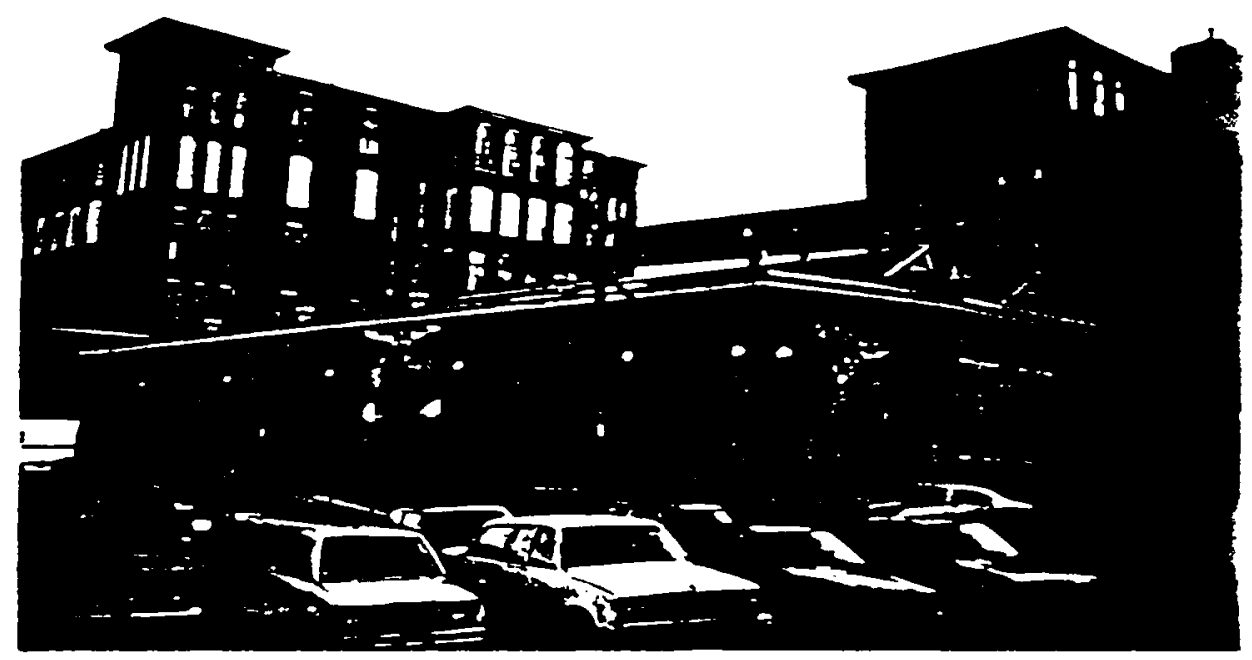

French Worsted Company 
Incoln

Albion M111 *

1830

Use: Condominiums

Condition: Excellent

Comment: Renovation recently completed. Raceway 18 overgrown but intact. Much surrounding open space.

Location 18 somewhat remote in Albion viliage; 1 will be of interest to see if the large bullding can be economically successful.

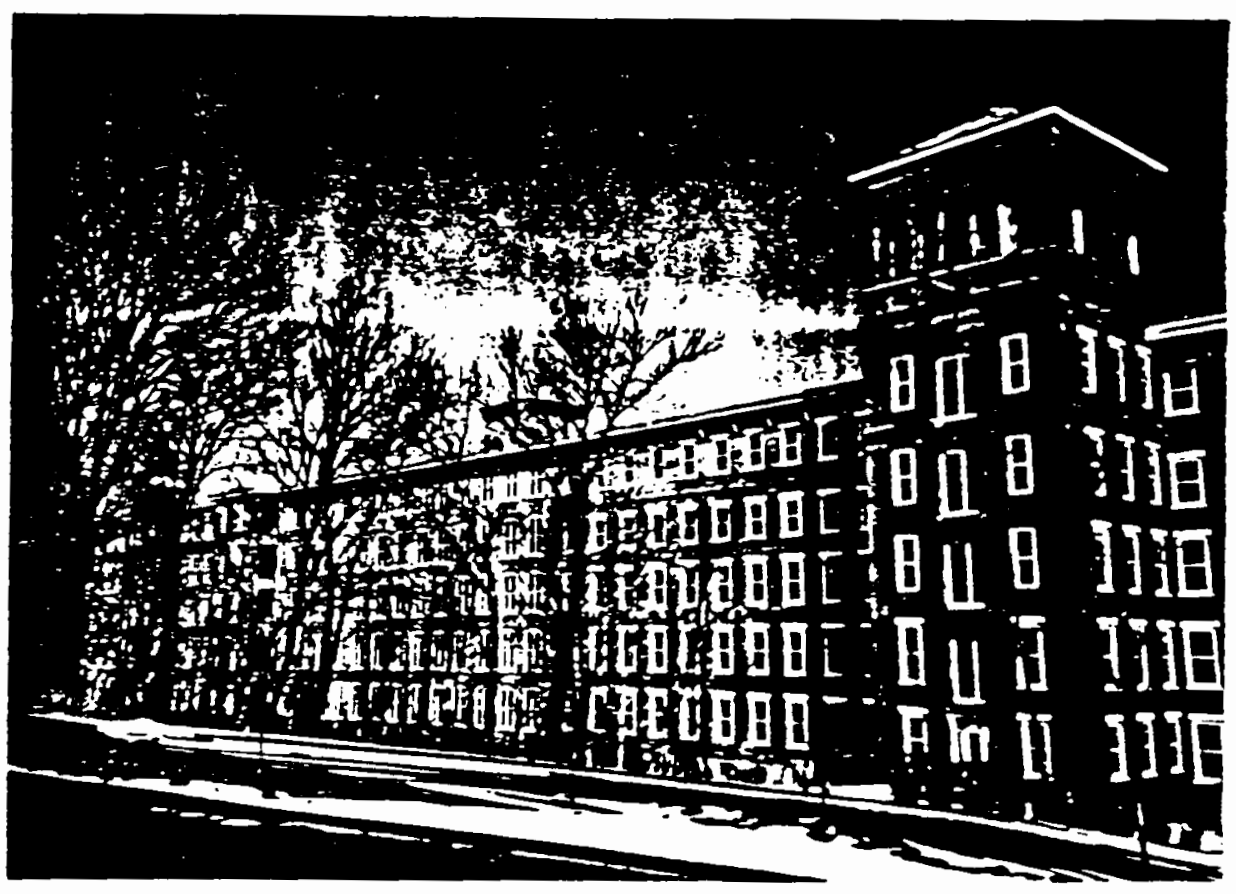

Albion Mill 
Cumberland

Ashton M111 *

1867

Use: Minimal industrial

Condition: Good - windows bricked over

Comment: Adjacent brick mill housing 18 intact and occupied.

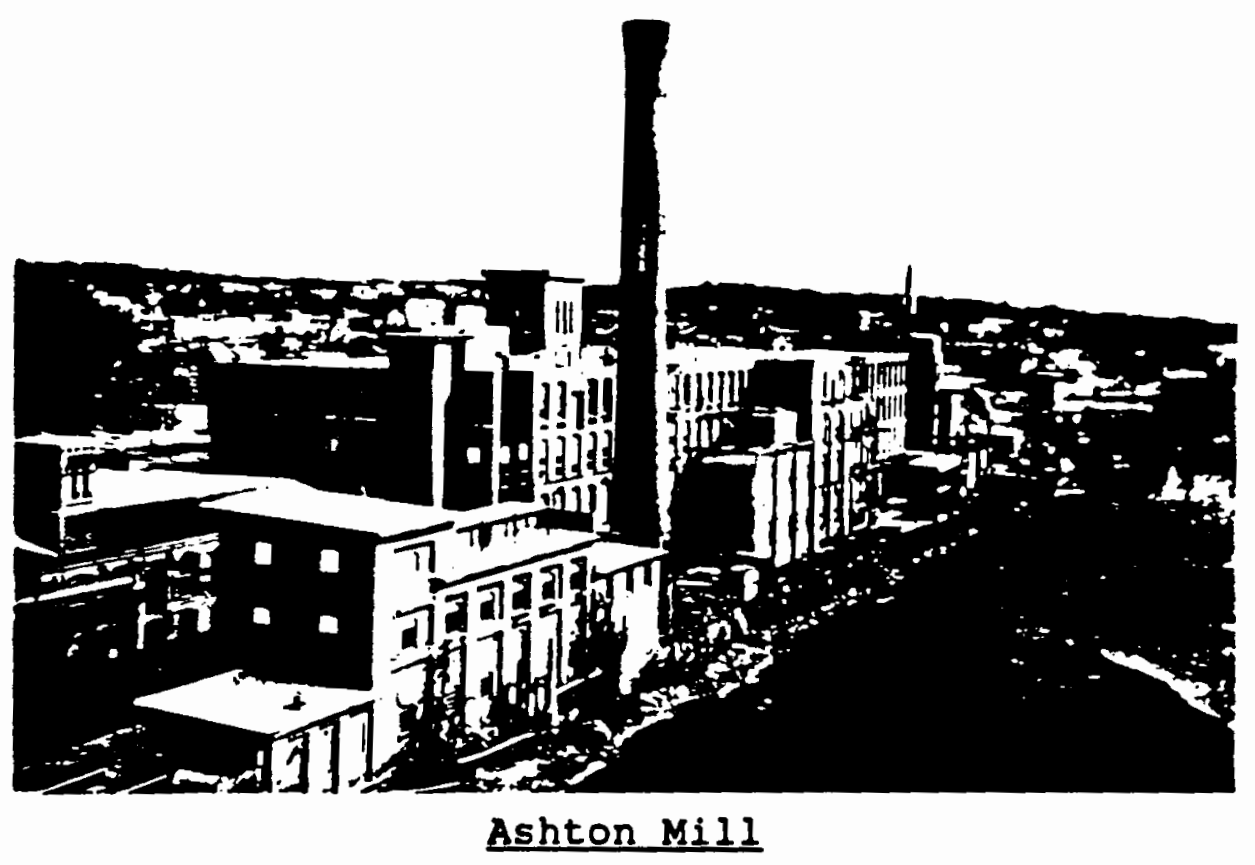


Cumberland

Berkeley Mill *

1872

Use: Some warehousing

Condition: Good

Comment: Handsome overall architecture. Romanesque tower. Nearly empty.
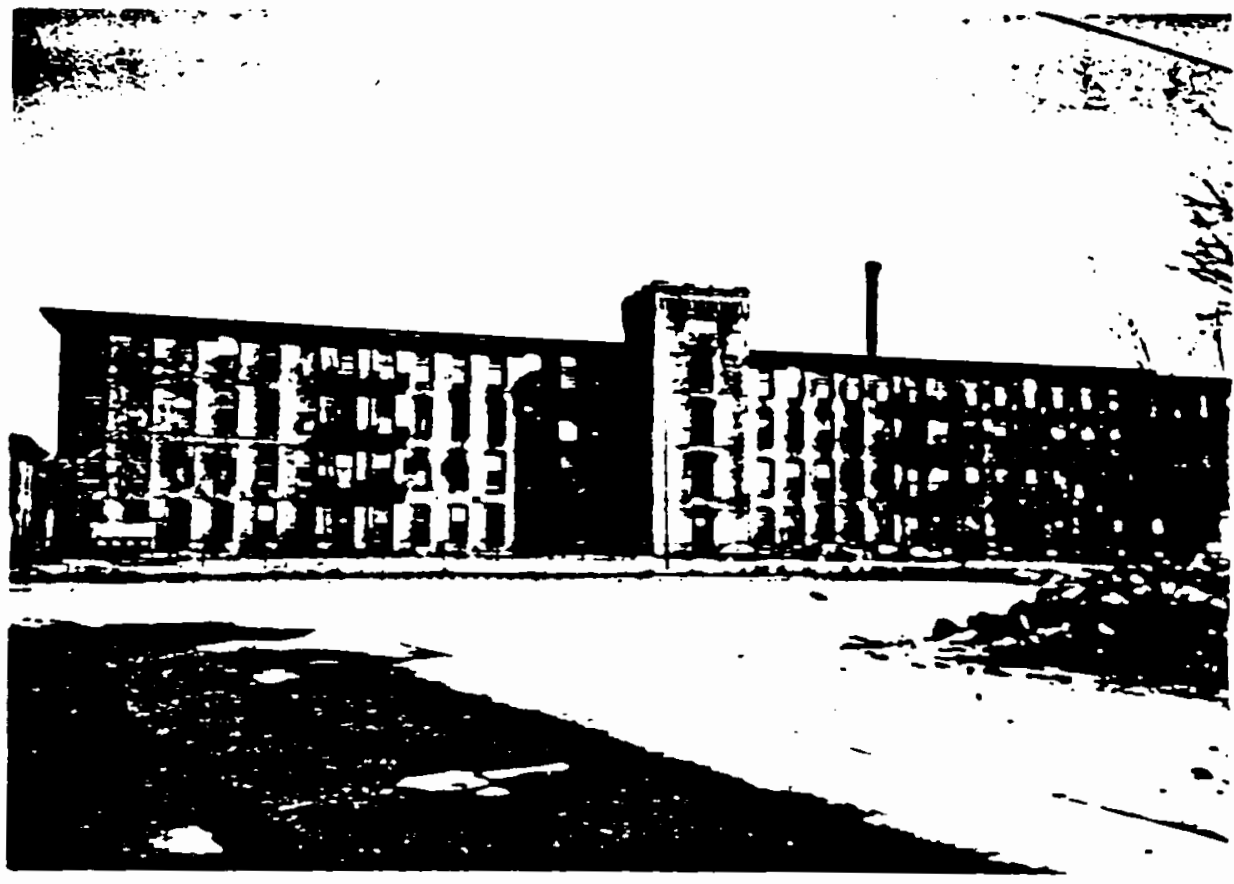

Berkeley Mill 
Incoln

Lonsdale Mills *

1833

Use: Mixed Industrlal/ commerclal, 1 retall outlet Cond1tion: Falr/ good

Comment: 13 structures; some renovated, some dilapldated.

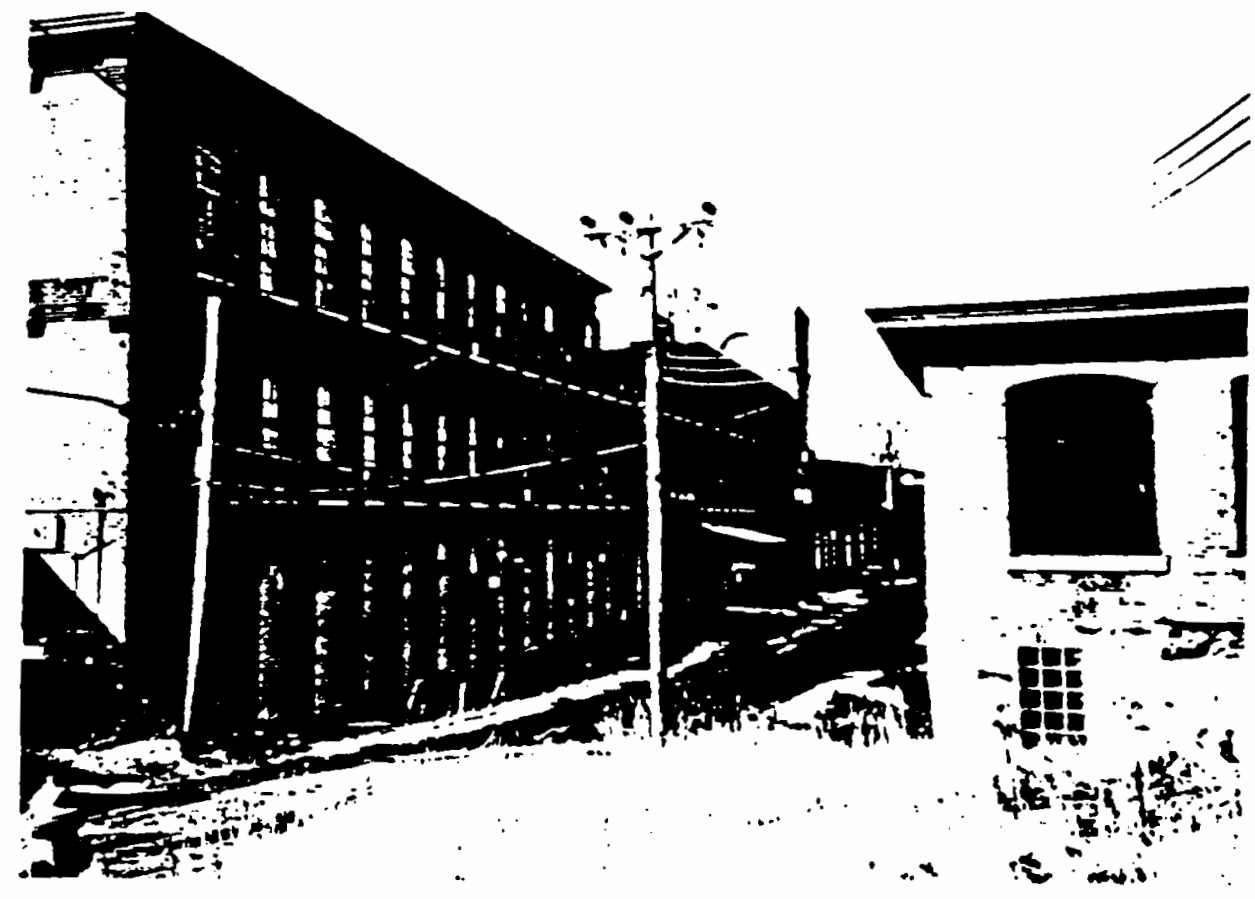

Lonsdale Mills 
Cumberland

Ann Hope M111 (Lonsdale Co.) *

1886

Use: Warehouse

Condition: Good

Comment: Retall outlet on bottom floor

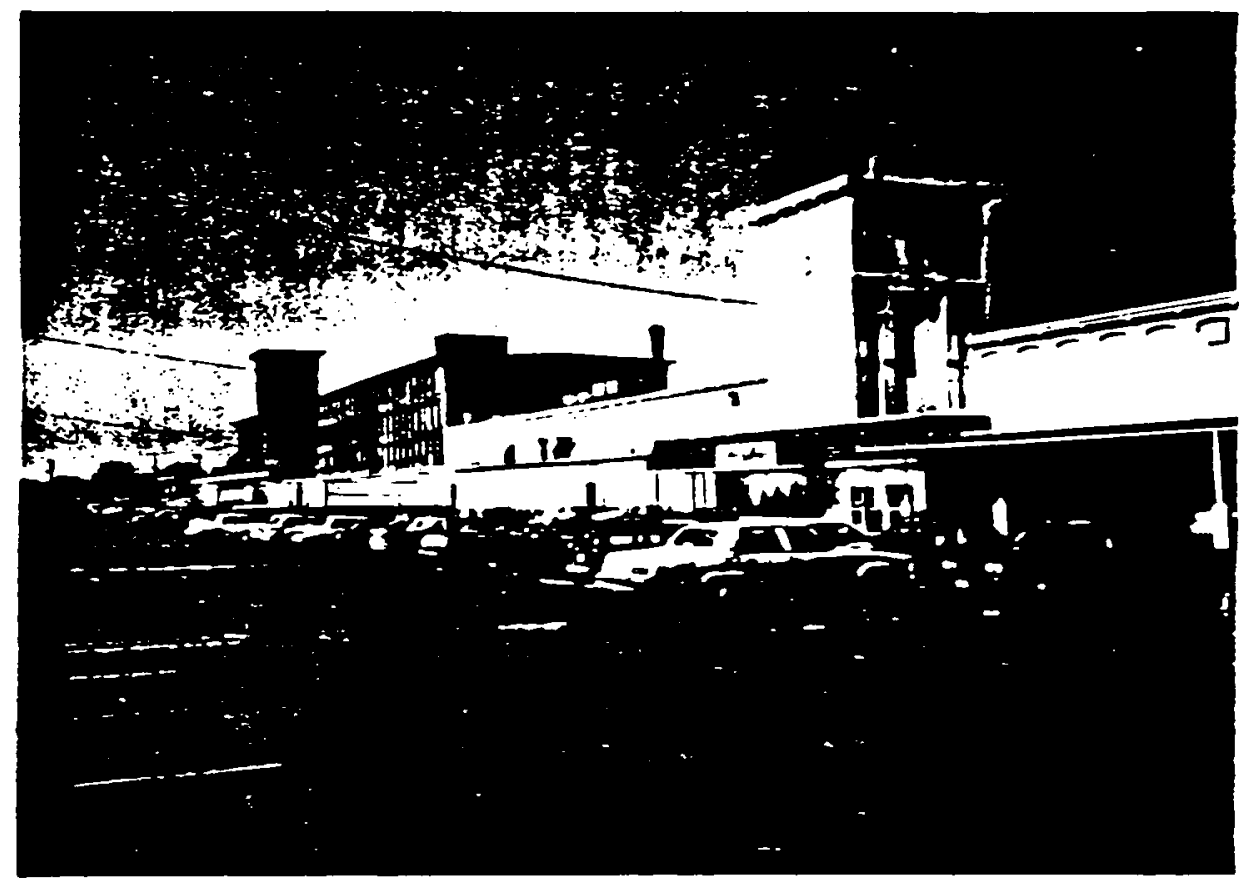

Ann \& Hope M111 
Central Falls

Valley Falls Company *

1849

Use: Residential

Condition: Excellent

Comment: Site of elderly housing project. 3 structures renovated to nursing home, 1 abandoned. Fine example of adaptive reuse.

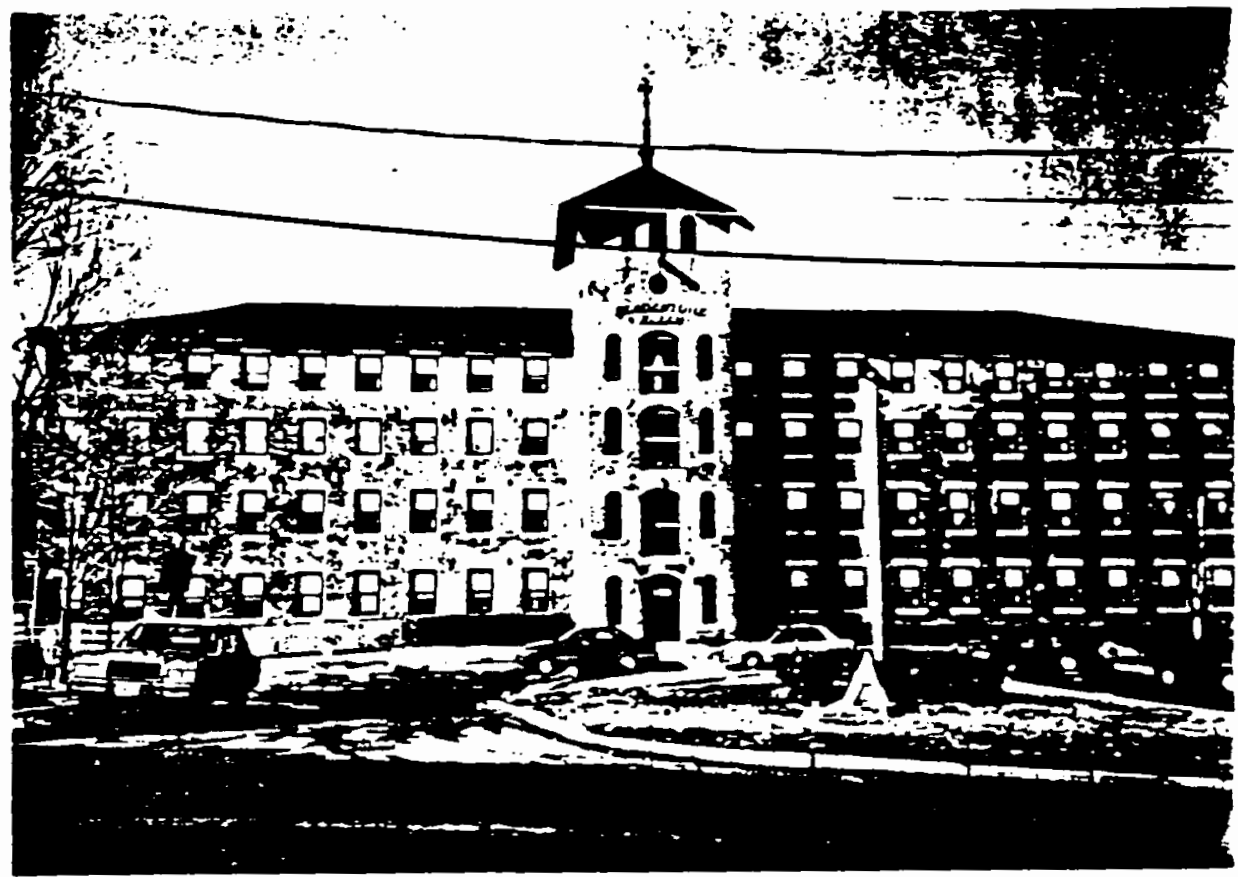

Valley Fal1s Company Mill 
Central Falls

Kennedy/stafford Mill *

1824

Use: Office industrial

Condition: Good - in process of renovation

Comment: Smaller than later mills. Use of brick 1s rare for mills from this period. Old dam on the river now produces hydro power.

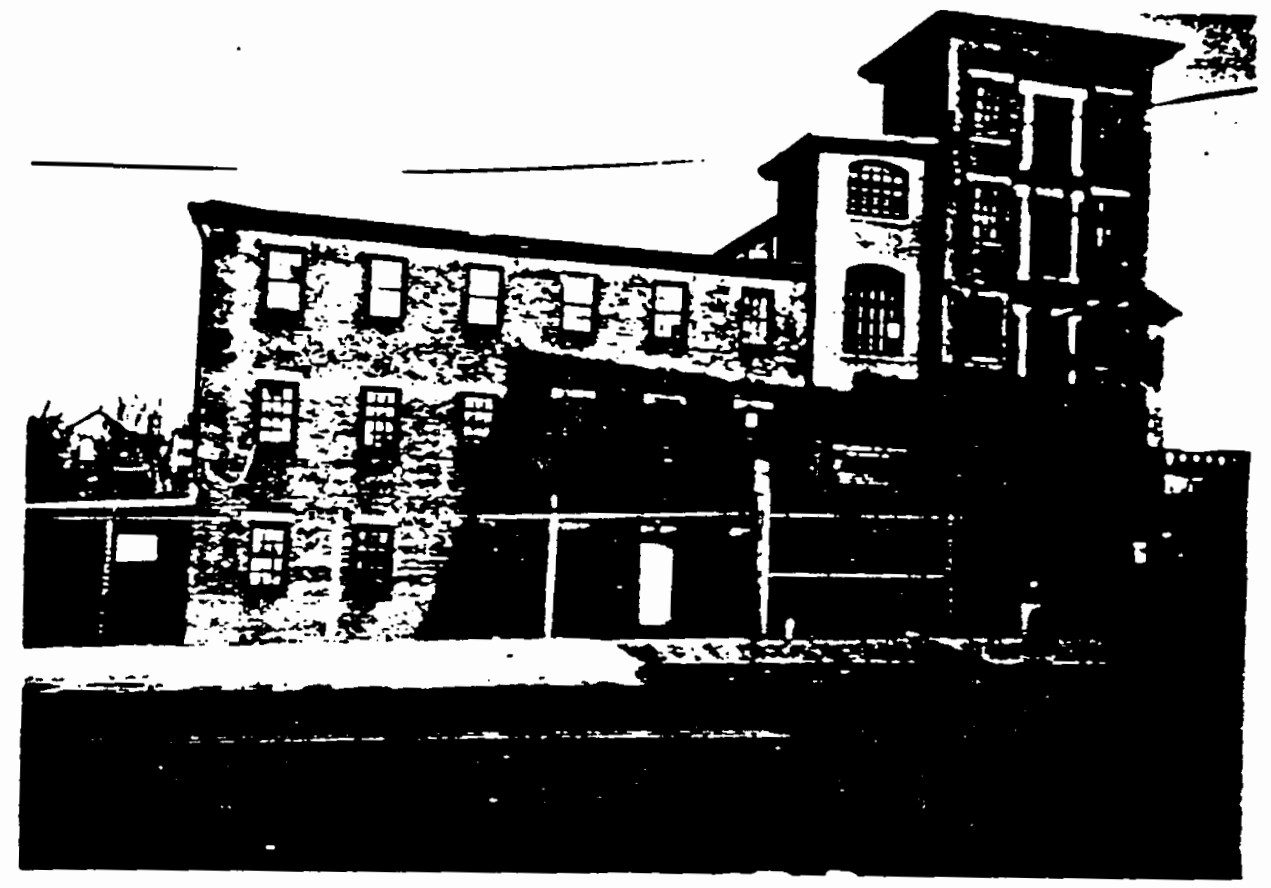

Kennedy/Stafford Mill 
Central Falls

Pawtucket Thread Manufacturing Company * 1825

Use: Industrlal

Condition: Falr

Comment: Not visible from street (behind Central Falls Woolen Co.). Built of rock and mortar.

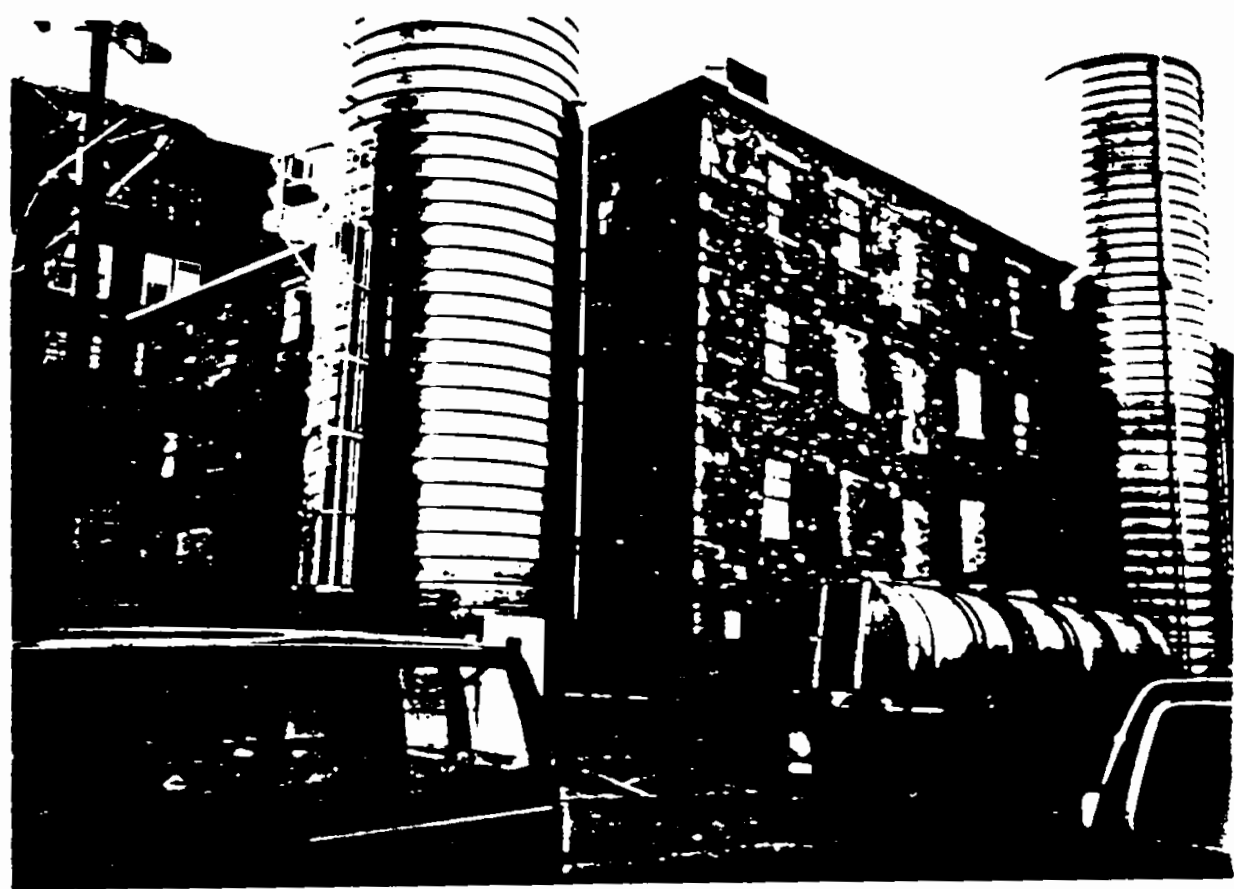

Pawtucket Thread Manufacturing Company 
Central Fal18

Pawtucket Hair Cloth M111 *

1864

Use: Some Industrial

Condition: Fair

Comment: Narrow roads inhibit industrial use.

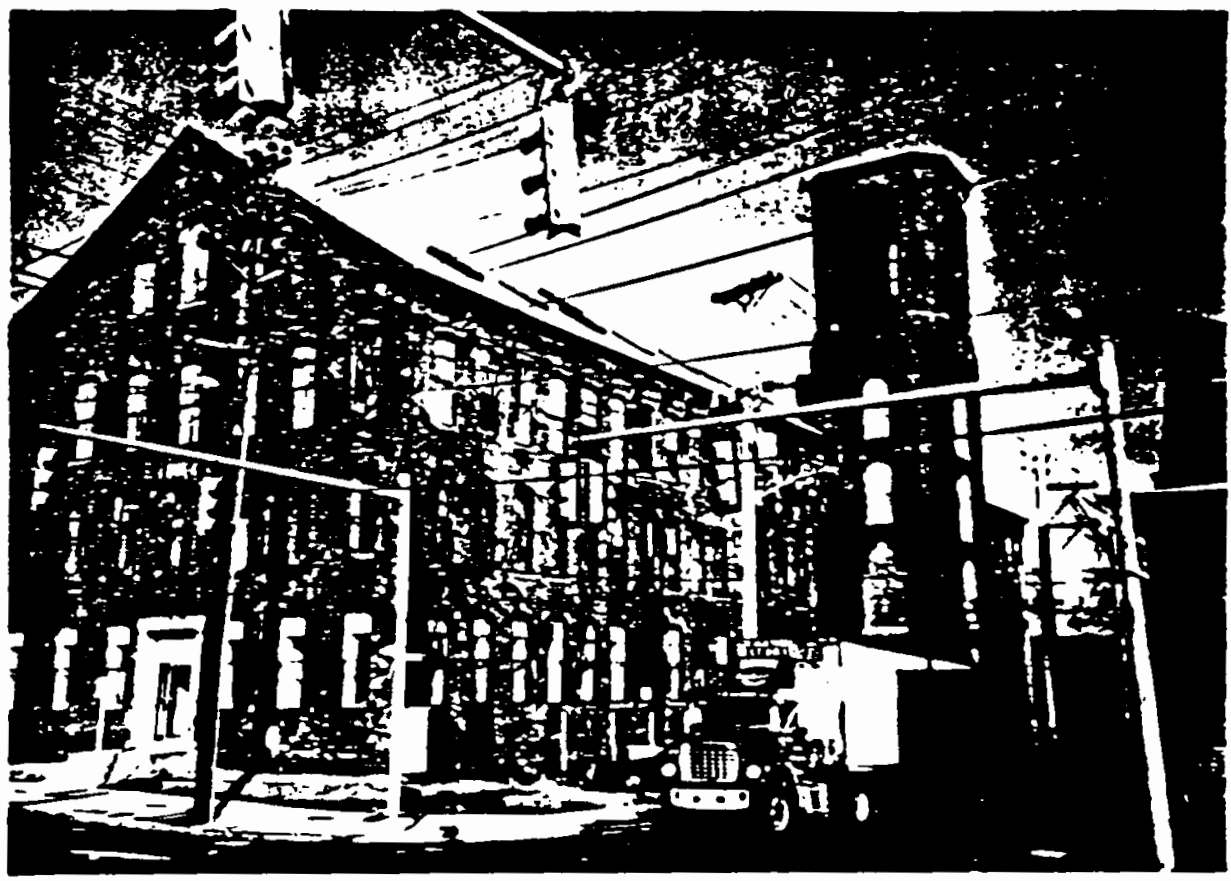

Pawtucket Halr cloth Company 


\section{Central Falls}

Central Falls Woolen Company *

1865

Use: Industrial

Condition: Good/ fair

Comment: Part of extensive historic industrial block.

Original tower and other architectural features were removed over time as mill was incorporated as part of new mill bullt to curb. Now owned by Elizabeth Webbing Company.

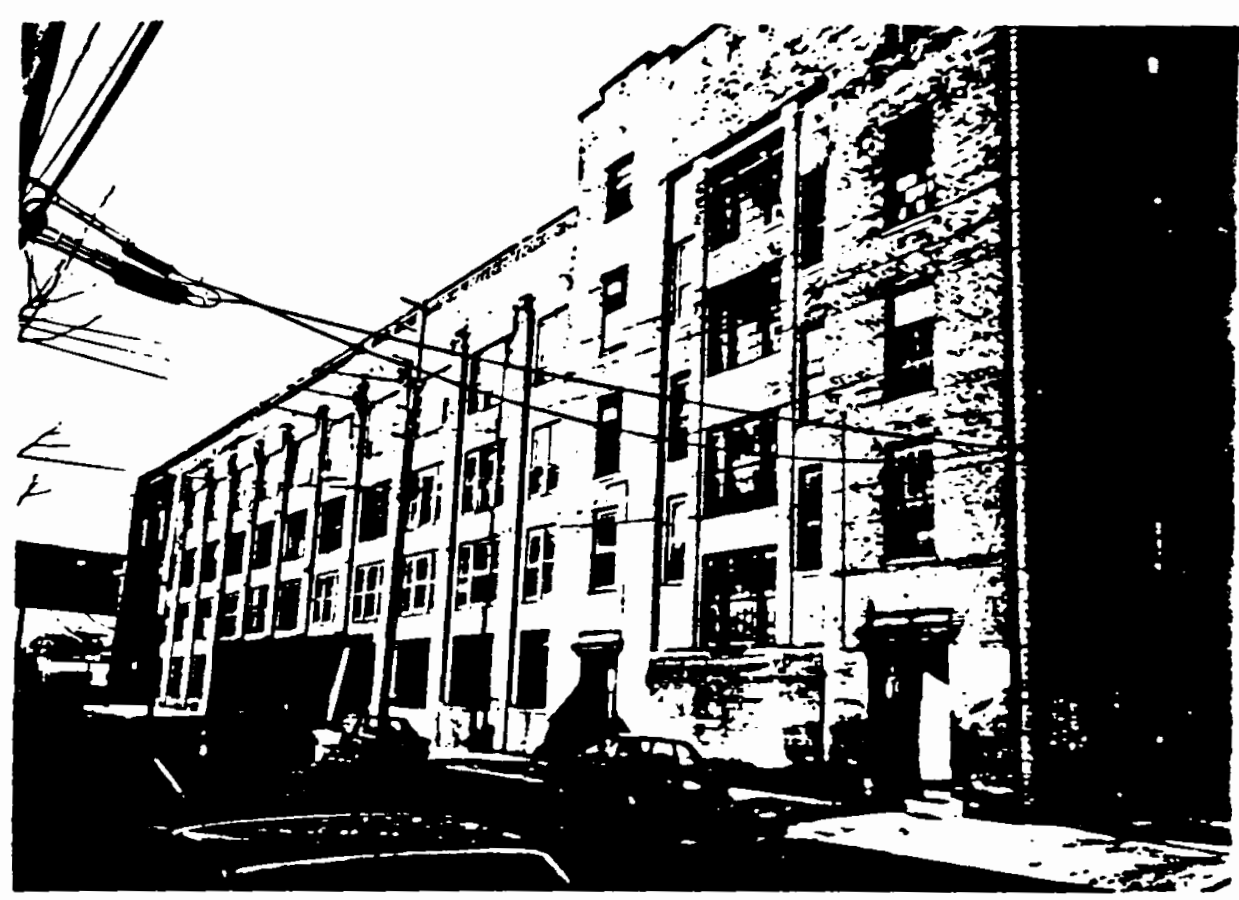

Central Falls Woolen Company 
Central ralis wil *

1897

Use: Appears vacant

comment: single story, saw to

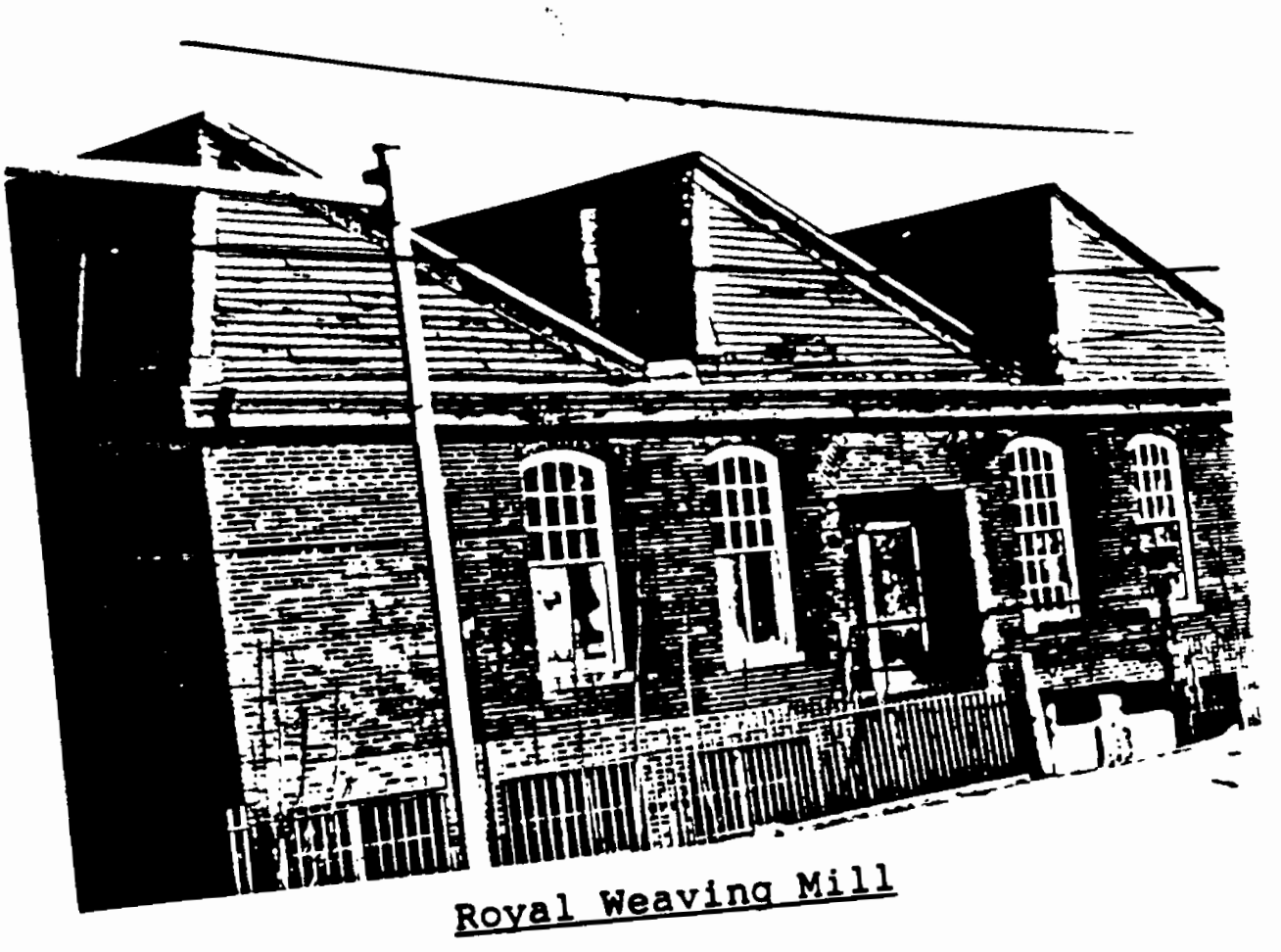


Pawtucket

Greene \& Daniels Manufacturing Company *

1860

Use: Condominiums

Condition: Excellent

Comment: Renovation completed. 808 occupancy.

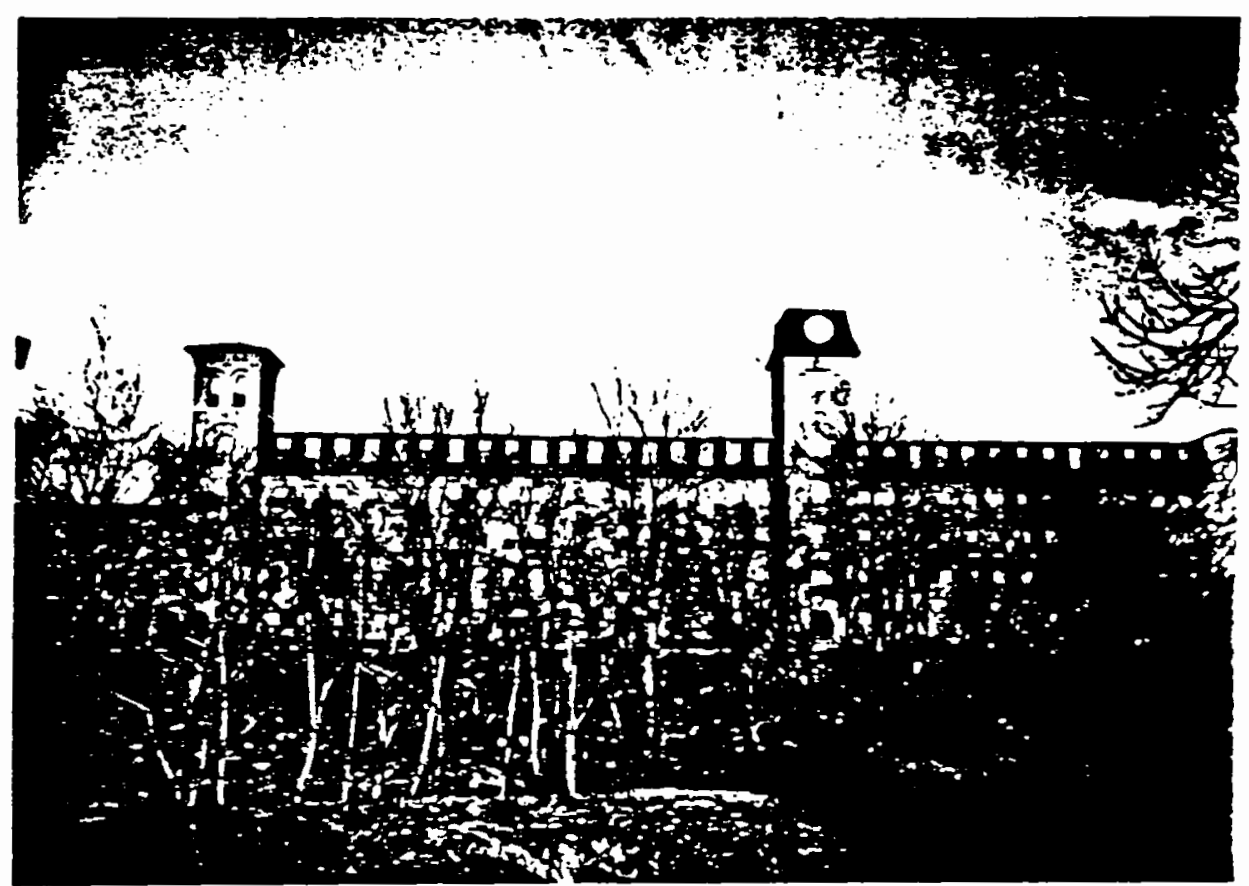

Green E Daniels Mill 
Pawtucket

Lebanon M111 *

1901

Use: Variety of industrial uses, one a jewelry manufacturer Condition: Good

Comment: Downtown location could be good for retall mall or other use.

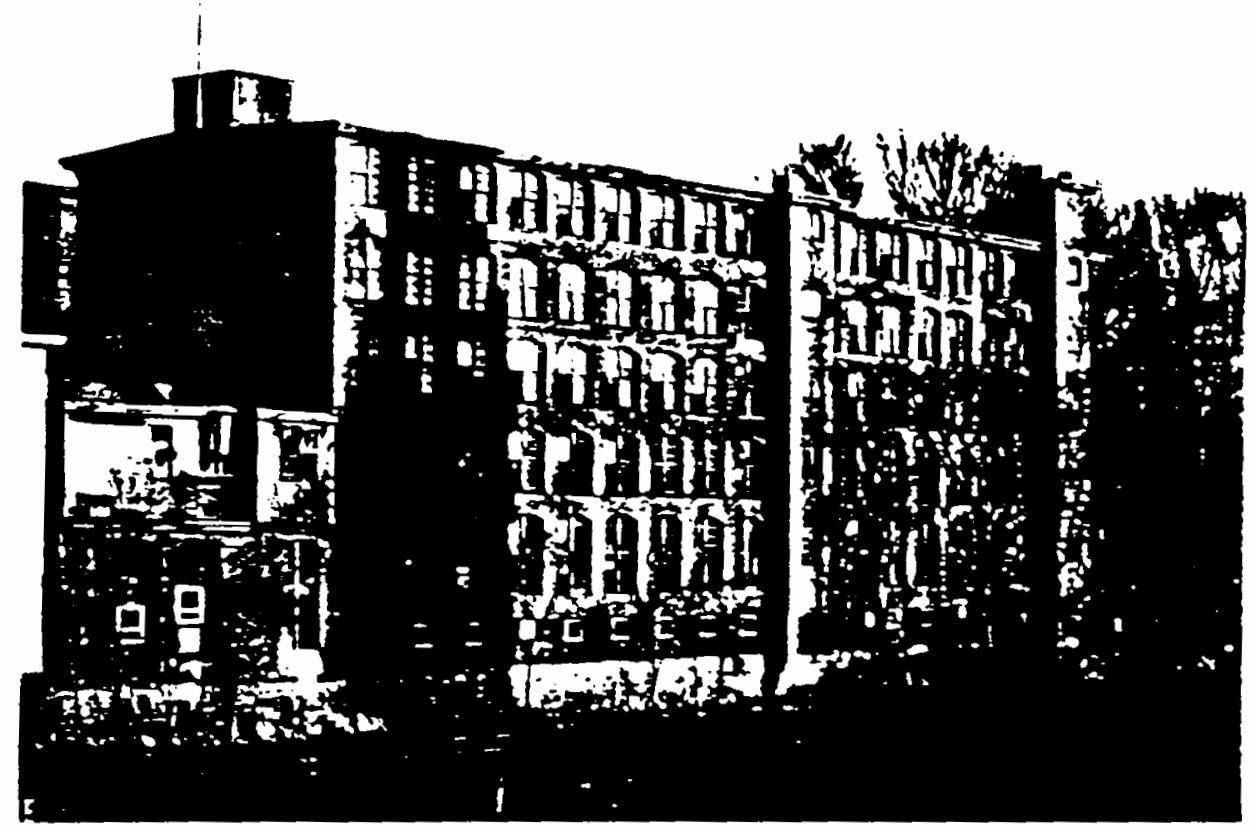

Lebanon Mill 
Pawtucket

Old Slater M111 *

1793

Use: Slater Mill Historic Site

Condition: Excellent

Comment: Oldest textile mill in North America

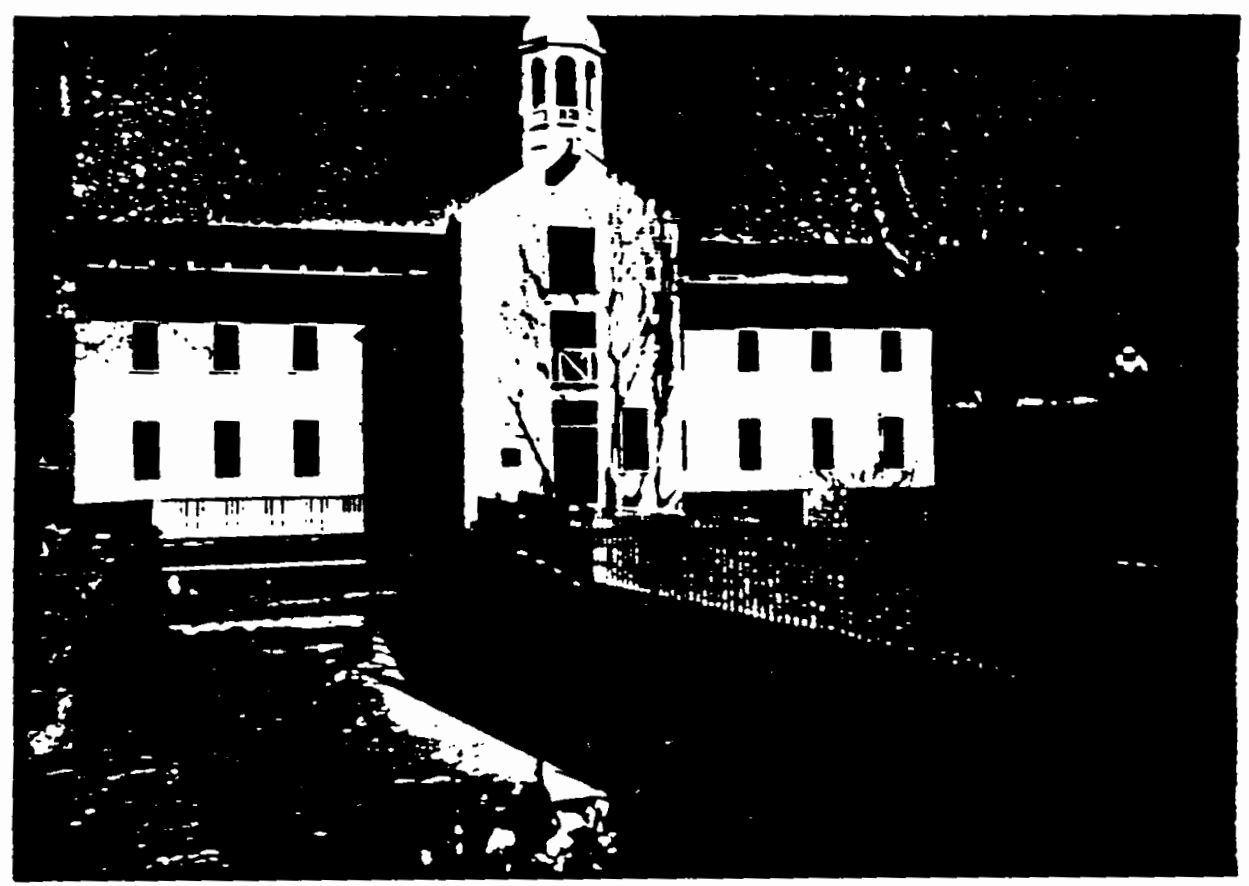

Old Slater Mill 
Pawtucket

Wilkinson M111*

1810

Use: Slater Mill Historlc Site

Condition: Excellent

Comment: Restored in 1970's. Re-use includes office space and storage, lower floor is 19 th century machine shop.

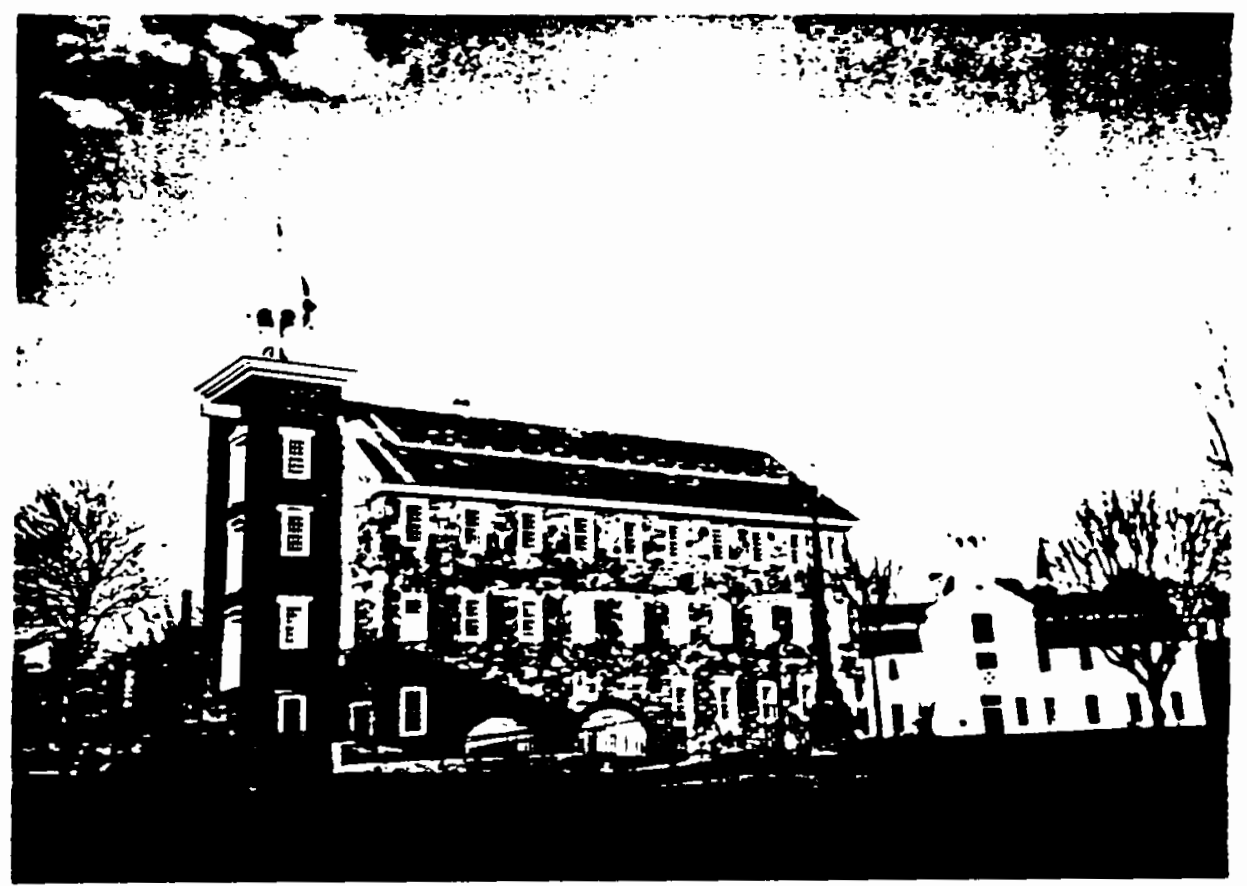

Wilkinson Mill 
CHAPTER 4, EVALUATION

In order to rate the mills by rational means, information was gathered on the criteria which are used to classify historic resources. Sources of information include the National Register of Historic Places, the Historic American Engineering Record, Advisory Council on Historic Preservation, and Rhode Island Historic Preservation Commission. This section of the project will define and explain the criteria used to evaluate mills in the study area. The National Historic Preservation Act defines historic resource as:

any prehistoric or historic district, site, building, structure, or object included in, or eligible for inclusion in the National Register; such term includes artifacts, records, and remains which are related to such a district, site, building, structure, or object. 13

The National Historic Register defines a historic property as:

a district, site, building, structure, or object significant in American history, architecture, engineering, archeology, or culture... It may be of value to the nation as a whole or important only to the community in which it is located. 14

Buildings are the primary focus of this study. Many of the mill sites contain historic structures such as dams and raceways. It is expected that any preservation efforts on mill buildings will take advantage of other on-site historic

13 National Register Bulletin No. 24. 1985. P.2.

14 National Register Bulletin No. 24. 1985. p.2. 
resources.

\section{Numerical Neighting}

The use of a numerical evaluation system for prioritizing preservation projects is an accepted planning practice. 15 Each category is given a value based on its contribution to the overall renovation potential of the building. A matrix of the evaluation's outcome allows the reader to see the relative value of each mill in each category. Each mill is scored according to the impact of a criterion on a mill's overall potential.

The evaluation classifications can be divided into two basic types: physical characteristics and cultural features. Physical features are tangible qualities such as construction materials, architectural features, and overall building condition. Cultural features include historic value, building age, and contemporary use. Below is an explanation of how each category is interpreted and applied to the listing of mills.

\section{Physical Peatures:}

Construction material - Mills in the Blackstone Valley were constructed of at least one of three basic materials: wood, stone, or brick. Wooden mills are the oldest and least common, so they are given highest value. Stone mills are also fairly rare. Mills built of brick have historic and

15 College Hill Demonstration Study. Providence: City Planning commission. 1967. This study has become the model for other planning efforts using a numerical evaluation system. 
aesthetic value, but receive the lowest score in relation to other construction materials from the mill era.

3 points - wooden mill

2 points - stone mill

1 point - brick mill

Architecture - Architectural significance of mills refers to overall style and individual features. Styles such as the Greek Revival of the Bernon Mill or the Medieval style of the Berkeley Mill are a reminder of 19 th century industrial architecture.

Architectural features of note are exterior towers, window and door designs, roof form, and cornices. Mills with more than two of the features listed below get a high value in evaluation. Mills with one or two features are ascribed medium value.

Arched belfry

Bracketed roof overhangs

clerestory monitor

Elaborate brickwork

Flat lintel windows

Monitor roof

Sawtooth roof
Bracketed cornice

Brick pier construction

Corbelied cornice

Exterior tower

Granite sills

Window transoms

Segmental arch windows

3 points - more than 2 features, recognizable style

2 points - 1 or 2 features, recognizable style or value

1 point - No observable architectural features of note

Photos of architectural features are found in the appendix of this report.

Size of building - Many mills in the Blackstone Valley are noteworthy because of the sheer size of the physical

structure. Expansive single rooms often exceed 50,000 square feet. This makes the mill suitable for adaptive 
reuses which require large floor areas such as indoor recreation. Smaller mills may be more suitable for retail/office use.

For the purposes of this report, the mills were ranked by size. While a larger mill may cost more to renovate, the amount of usable floor area can be significantly greater. Reuse of a single larger mill for retail, commercial, or residential space can have a significant impact on a community's economy. The size category is broken down below.

3 points - large mill

2 points - moderate sized mill

1 point - small mill

Building condition - Each mill is categorized by its physical appearance as excellent, good, fair, or poor. The assessment was made by visual inspection of the exterior, and does not reflect interior condition.

Mill described as excellent are those which show evidence of consistent maintenance or were recently renovated. A "good" classification means that the building appears sound with no structural defects. "Fair" signifies that one or two moderate repairs are required, but the building can be renovated fairly easily. A "poor" rating indicates the appearance of major physical inadequacies. This could mean a disjointed or missing roof, broken windows, crumbling walls, in general a building which will require a major overhaul before reuse occurs. Building 
condition is classified numerically as follows:

4 points - excellent condition

3 points - good condition

2 points - fair condition

1 point - poor condition

\section{Cultural Qualities:}

Historic listing - Historic value is based on the building's inclusion on national, state, and local historic registers. If a building is listed on the National Register of Historic Places, it received the highest ranking. Inclusion on the Rhode Island Register or a local historic register gave the building a medium historic rating. Any building which was not listed as a federal, state, or local historic building received the lowest ranking.

3 points - federal designation

2 points - state register

1 point - local register only

Significance - The significance of any one resource must be evaluated within the overall historic context of the area. ${ }^{16}$ site characteristics which combine to make a mill significant are:

* Historically significant events

* Period of time the mill achieved its importance

* Specific events at the site

* Historically significant persons associated with the property.

* Property's impact on the overall development of the textile industry.

Mills which were first to incorporate a technological improvement or which employed a unique industrial method or

16 National Register Bulletin No. 24. 1985. P.45. 
system have a higher value than mills which used ordinary production methods. Bernon Mill, for example is one of the earliest known examples of "slow-burning" construction; Lafayette Worsted Company Mill was the site of the first use of the Roubaix spinning system.

Rating the significance of an individual historic property is a subjective task. The author utilized previous historic surveys, anecdotal data, and personal judgement to categorize the overall significance of each mill. The rating system is as follows:

3 points - highly significant

2 points - some significance

1 point - little significance.

Age of building - Mills constructed before 1840 were generally of the smaller early slater type. ${ }^{17}$ They get the highest rating for historic preservation. Buildings constructed between 1841 and 1890 have a medium value. Buildings built between 1891 and 1910 have the lowest value.

No buildings constructed after 1910 are included in this study. This is because factors which caused the decline of Northeast textile mills were already entrenched. Consequently, few mills were constructed after that date, and the few which were built used concrete as a building material. Ratings for building age are as below.

3 points - constructed before 1840

2 points - constructed 1841- 1890

17 U.S. National Park Service. Blackstone River Corridor Study: Conservation options. Pp. 18-19. 
1 point - constructed after 1891

current use - This category measures the level of industrial or other activity currently in the building. Most mills, if they are still used, retain at least a portion of use in industry, some in the textile industry (Nyanza Mill). other mills have seen a shift to different industrial use (Blackstone Mill). In some cases, the classification of use has been completely changed. Valley Falls Mill in central Falls has been rehabilitated as a nursing home for elderly. Greene Daniels Mill is a recently completed condominium conversion.

Whatever the current use may be, the highest value for renovation/reuse has been assigned to mills which are currently vacant. Mills with some present use get a medium value. Mills which operate or are rented at full capacity get a low score. This is because any adaptive reuse plan would interfere with existing economic activity.

Given the number of outdated industrial sites in New England and the current real estate market, a vacant facility can probably be purchased for a moderate price. A mill which is currently in some use is generating revenue for its owner; this could make some owners unwilling to sell or renovate their property.

3 points - structures currently vacant

2 points - marginal use

1 point - Building occupied at capacity

Location in community - Location in the community or 
distance to a population center is a key factor in assessing the reuse potential of an historic structure. Sites located in densely populated high-traffic areas may be adapted to suit the needs of nearby residents. Retail and other commercial activities may work well in such areas. Sites which are remote to population centers may be best suited for continued industrial use only.

Another factor in the location quotient is access to the highway system. A successful industrial site must have easy access to other communities by truck. A site such as the Albion Mill in Lincoln (recently completed condominium renovation) may be at a disadvantage in attracting occupants because of its rural location.

Mills in densely populated areas with easy transportation access get the highest score in this category. A medium score indicates either location in a populated area or good transportation access. Rural areas are assigned the lowest point value because of their market disadvantage.

6 points - Location ideal for reuse

4 points - Location good for reuse, some obstacles

2 points - Location is not a positive factor

Reuse potential - All scores were tabulated. Mills which received the highest ratings were deemed to have the greatest potential for future renovation/reuse.

Miscellaneous factors such as environmental constraints and local zoning and tax laws must be evaluated on a case by 
case basis to distinguish between mills which may be used for economic gain and those which have historic/cultural value only. Refer to the matrix on the following pages. 
Mills are arranged North to South

\begin{tabular}{|c|c|c|c|c|c|c|c|c|c|c|}
\hline Mill & 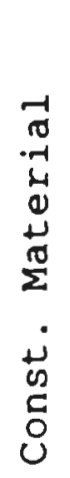 & 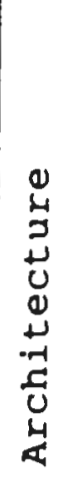 & 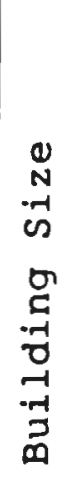 & $\begin{array}{c}5 \\
0 \\
-1 \\
+口 \\
-1 \\
0 \\
0 \\
0 \\
0\end{array}$ & 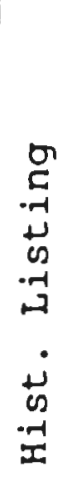 & 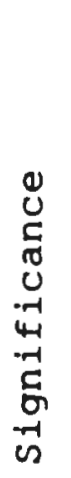 & $\stackrel{0}{G}$ & 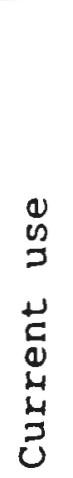 & 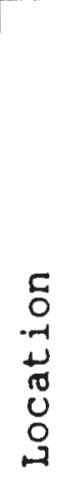 & 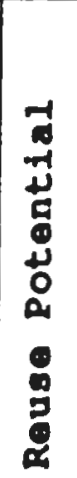 \\
\hline slatersville & 2 & 2 & 1 & 3 & 3 & 3 & 3 & 3 & 6 & 26 \\
\hline Blackstone & 1 & 2 & 2 & 3 & 2 & 1 & 1 & 2 & 6 & 20 \\
\hline Samoset/Nyanza & 1 & 1 & 2 & 4 & 1 & 1 & 1 & 2 & 4 & 17 \\
\hline Alice & 1 & 2 & 3 & 3 & 1 & 2 & 2 & 1 & 4 & 19 \\
\hline J. Desurmont & 1 & 2 & 3 & 3 & 1 & 2 & 1 & 1 & 4 & 18 \\
\hline Glenark & 1 & 3 & 2 & 4 & 2 & 2 & 2 & 1 & 4 & 21 \\
\hline Falls Yarn & 2 & 2 & 1 & 1 & 3 & 3 & 2 & 3 & 6 & 23 \\
\hline Ballou/Lippitt & 3 & 2 & 2 & 4 & 2 & 3 & 2 & 1 & 6 & 25 \\
\hline Harris \#2 & 3 & 1 & 2 & 3 & 2 & 3 & 2 & 1 & 6 & 24 \\
\hline $\begin{array}{l}\text { Narragansett } \\
\text { Knitting }\end{array}$ & 1 & 1 & 2 & 3 & 1 & 1 & 1 & 2 & 6 & 16 \\
\hline Bernon & 2 & 3 & 2 & 2 & 3 & 3 & 3 & 2 & 4 & 24 \\
\hline River Spinning & 1 & 1 & 2 & 3 & 1 & 1 & 1 & 1 & 4 & 15 \\
\hline Lafayette & 1 & 1 & 3 & 3 & 1 & 2 & 2 & 1 & 4 & 18 \\
\hline Erench worsted & 1 & 1 & 3 & 3 & 1 & 1 & 1 & 1 & 4 & 15 \\
\hline Albion & 1 & 3 & 3 & 4 & 3 & 3 & 3 & 1 & 2 & 23 \\
\hline Ashton & 1 & 2 & 3 & 3 & 3 & 3 & 2 & 3 & $\div$ & 24 \\
\hline Berkeley & 1 & 2 & 3 & 2 & 3 & 2 & 2 & 2 & 2 & 19 \\
\hline
\end{tabular}




\begin{tabular}{|c|c|c|c|c|c|c|c|c|c|c|}
\hline Mil1 & 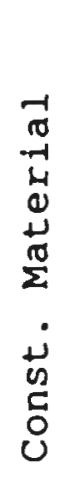 & 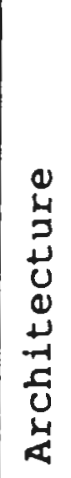 & 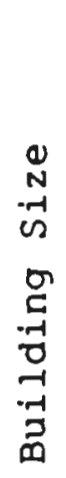 & 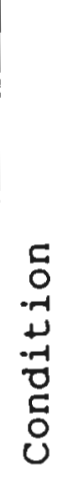 & 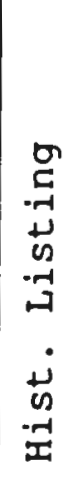 & 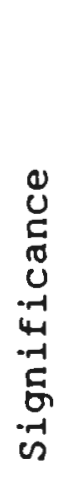 & ỡ & 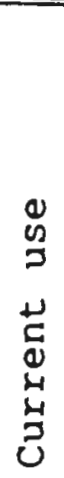 & 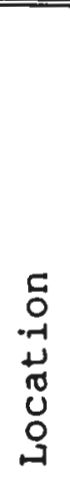 & 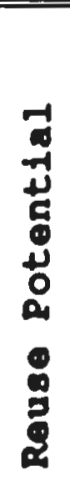 \\
\hline Lonsdale & 1 & 2 & 2 & 2 & 2 & 3 & 3 & 2 & 4 & 21 \\
\hline Ann \& Hope & 1 & 2 & 3 & 3 & 1 & 1 & 2 & 2 & 4 & 19 \\
\hline Valley Falls & 1 & 3 & 2 & 4 & 2 & 3 & 2 & 1 & 4 & 22 \\
\hline Stafford & 1 & 3 & 1 & 3 & 2 & 2 & 3 & 2 & 4 & 21 \\
\hline Pawt. Thread & 2 & 2 & 1 & 2 & 2 & 3 & 3 & 2 & 4 & 21 \\
\hline C.F. Woolen & 1 & 1 & 2 & 2 & 1 & 1 & 2 & 2 & 4 & 16 \\
\hline $\begin{array}{l}\text { Pawt. Hair } \\
\text { Cloth }\end{array}$ & 1 & 3 & 2 & 3 & 1 & 1 & 2 & 2 & 4 & 19 \\
\hline Royal Weaving & 1 & 1 & 2 & 1 & 1 & 1 & 1 & 3 & 4 & 15 \\
\hline $\begin{array}{l}\text { Greene \& } \\
\text { Daniels }\end{array}$ & 1 & 1 & 3 & 4 & 1 & 1 & 2 & 1 & 6 & 20 \\
\hline Lebanon & 1 & 1 & 3 & 3 & 1 & 1 & 1 & 2 & 4 & 17 \\
\hline Old Slater & 3 & 2 & 1 & 4 & 3 & 3 & 3 & 1 & 6 & 26 \\
\hline Wilkinson & 2 & 3 & 1 & 4 & 3 & 3 & 3 & 1 & 6 & 26 \\
\hline
\end{tabular}


Iisting of Mills in order of Reuse Potential

Yi11

Slatersville Mill

old slater Mill

Wilkinson Mill

Ballou/Lippitt Mill *

Harris 2

Bernon Mills

Ashton Mill

Falls Yarn Mill

Albion Mill *

Valley Falls Mill

Glenark Mill

Lonsdale Mills

Stafford/Kennedy Mill

Pawtucket Thread

Blackstone Mill

Greene \& Daniels Mill *

Alice Mill

Berkeley Mill

Ann \& Hope Mill

Pawtucket Hair Cloth

Jules Desurmont

Lafayette Mill

Samoset and Nyanza Mills *

Lebanon Mill

Narragansett Knitting Mills

Central Falls Woolen

River Spinning Company

French Worsted Mill

Royal Weaving

\section{Reuse Potential}

26

26

26

25

24

24

24

23

23

22

21

21

21

21

20

20

19

19

19

19

18

18

17

17

16

16

15

15

15

- Denotes renovation has been completed on these mills 


\section{Findings of Matrix}

The system of numerical evaluation served to help the researcher combine an array of related and unrelated characteristics to determine the relative value of existing mills. The numerical score in the far right column of the table is an indicator of each mill's reuse potential compared to other mills in the study. A discussion of the study's results will help put the overall analysis in context with the prognosis for future action.

This study attempted to evaluate all the mills along the Rhode Island section of the Blackstone River. Current use of the site was not a consideration in including a mill in the study. Some mills which were evaluated have been recently renovated. Their score in the matrix is a reflection of the overall value of those mills compared to mills which have not been renovated.

The discussion below describes the overall value of each mill based on the evaluation process. Key elements of each mill are described to give the reader a more precise understanding of reuse/renovation feasibility. The mills are addressed in descending order from north to south, just as they appear in the matrix.

\section{Parcel specific findings}

slatersville Mill - slatersville mill, the northernmost site in the study, received the highest overall score of any mill. Its potential for adaptive reuse was judged to be 
similar to old slater and Wilkinson mills in Pawtucket, which currently serve as museums of industrial heritage.

Slatersville Mill benefits from outside characteristics. Its locale in the early mill town of slatersville, which contains extensive architecture and mechanical artifacts from the period, makes it a perfect location for contemporary uses which would befit an historic setting. Many original dams and raceways from the waterpower era survive. Judging from the author's observation of the site in early 1992, it appears that the property is currently vacant.

The North Smithfield Comprehensive Plan mentions the mill as an ideal site for economic development. The mill could conceivably house office space on the upper floors with a first floor devoted to retail. Another possibility would be to develop the site as studio type apartments while maintaining its historic integrity. The U.S. Park Service currently conducts tours of the historic village. Blackstone Mill - Blackstone Mill received a median score. It received high scores for its physical condition and location in the community, but has little historic or architectural significance. At first glance one would judge the structure to be extremely sound. However, property manager Armen Harootian said that the roof of the main building was beginning to deteriorate and needed replacing, 
a very costly repair. ${ }^{18}$

An interview with Mr. Harootian also revealed a number of distressing factors which undermine profitable use of the Blackstone mill. Foremost is inadequate access to a major highway. Trucks which frequent the complex must pass through the center of Blackstone, Massachusetts to reach Route 146. Because of this, the Blackstone mill would probably be most suitable for non-industrial uses. Samoset Mill and Nyanza Mill - This set of two early 20th century mills had few features which make it valuable as an historic site. The only category it got a high score in was for physical condition. The mills have experienced some renovation, mostly in the form of modern windows and doors. The buildings are still in industrial use. Alice Mill - Alice Mill got a lower median value. The impressive facade and twin tower construction make it a local landmark. The owner, Tech Industries, still uses most of the interior space. The mill and operation should be allowed to exist in its current state, with care taken to preserve the facade and structural integrity of the building.

Jules Desurmont Worsted Mill - Desurmont Mill, located 100 feet south of Alice Mill, also received a lower median score. The mill is currently used for manufacturing, but

18 Interview with Armen Harootian, Blackstone-North Smithfield Industrial Corporation, North smithfield, Rhode Island, February 28,1992 . 
employs fewer people than Alice Mill. While the architecture is not old, the mill is a good example of brick pier construction, a late innovation in brick textile mills. The large tract of open space between the mill and the river could be used as a park inside the corridor.

Glenark Mill - Glenark Mill received a medium score, having moderately valuable architecture and historic significance. It has been used at for cotton processing, knitting, worsted production, and as a dyeworks. It is situated adjacent to the river with a dam a few feet downstream, making it a visually pleasing element of the neighborhood northwest of downtown Woonsocket. The mill has been completely renovated in a tasteful fashion, with all building facades maintaining their original character. The building serves as an apartment complex.

Falls Yarn Mills Building - This abandoned and unrestored building on Market Square in Woonsocket achieved one of the highest overall scores of all structures. Originally built of stone, it has at various times been altered with brick and concrete supports and appendages. Location and historic significance give this building an excellent prognosis for adaptive reuse. The site is projected as office space for Woonsocket's Chamber of Commerce and the Blackstone River Valley National Heritage Visitor Center. ${ }^{19}$ No renovation

19 Historic Blackstone Riverfront, Master Plan. 1989. Providence: Albert Veri Associates, Inc. 
work on the mill has be started.

Ballou/Lippitt Woolen Mill - This moderate size mill has achieved its potential for renovation/reuse. The old mill has been converted into an elderly housing facility on Main Street in Woonsocket, the city with the oldest population in Rhode Island. It did not get an unfavorable score in any category. Location in the downtown is a key element of its value. The building is located on Main street, having derived water power from the Lyman Trench. 20 The trench is partially filled, but can still be observed in front of the Ballou/Lippitt Mill.

The overall approach to the renovation project has preserved all facades in their original condition. This structure deserves inspection as it is one of the finest examples of adaptive reuse in the study area. Its moderate size may have been a factor in the project's feasibility. Harris Mill Number 2 - Harris $\$ 2$ received a very high score for its reuse potential. Located on Main street, the mill also has access from Truman Drive, a divided highway. The six stories are in various states of repair, some rear windows having been recently replaced, while the south wall still contains brick and mortar covered openings.

20 Lyman Trench was a canal which diverted water from above woonsocket Falls to power a series of nearby textile mills. Now partially covered over, the Trench consisted of a main spillway paralleling Main street and a series of right angle power raceways. More information on the history of Lyman Trench can be found in Dr. A. P. Thomas, woonsocket, Highlights of History, 1800-1976, 1976. 
The mill's prime feature is the stone and wood construction and favorable state of repair. A retail addition on the Main street side of the building sits over the Lyman Trench, the historic power source for mills in this area. Partially restored, the mill appears to accommodate commercial use at the street level and housing in the upper floors.

Narragansett Knitting Mills - This series of brick and late wooden mills offered little in the interest of historic preservation. Some of the older brick buildings have interesting window arches, sills, and utility openings. Their moderate size may make some adaptive reuse feasible. The best use of these buildings is to continue as industrial space.

Bernon Mills - Two beautiful mills from the early mill era, the Bernon mills have potential to become showpieces of woonsocket's industrial heritage. Among unrestored structures in the study, only slatersville mill was accorded a higher reuse potential. Uncoursed granite construction, simple architecture, and clerestory monitor evoke the idea of the archetypical textile mill. The earlier building is one of the earliest-known examples of "slow-burning" construction.

Bernon Mills sit adjacent to the river on a high berm. As such, they already have the visual element of good urban design. The possibilities for adaptive reuse include 
commercial space and residential use.

River Spinning Mill - River Spinning Mill tabulated the lowest score in the study. The mill is situated along the Blackstone River but used steam engines to generate power. This does not mean that the mill has no value to the community. Currently used by ACS Industries, the site continues as part of Woonsocket's industrial base. The building appears to be in excellent condition. Noted architectural features are brick pier construction and an end tower with interesting medieval-type brickwork. Lafayette Mill - Across a narrow street from French Worsted Mill, Lafayette Mill achieved a slightly higher value. This is due primarily to its significance in the immigration of French labor into the New England textile industry. Lafayette was also the first firm to import French technology, the Roubaix system, for the spinning of worsted yarn. 21

French Worsted company - French Worsted also got a very low score. The mill appears to be operating as manufacturing, but the product is not known. Architecturally undefined this structure should be continued in its utilitarian function.

Albion Mill - An enormous mill on a rural stretch of the Blackstone, Albion Mill has recently been renovated as

21 Gary Kulik and Julia C. Bonham. Rhode Island: An Inventory of Historic Engineering and Industrial Sites. P. 276. 
condominiums. The mill scored high on nearly every category, and so was an excellent choice for renovation. Raceways and some millworks still survive on the grounds.

The size of Albion Mill as an adaptive reuse project makes it an interesting case study. The building is nearly 400 feet long and five stories tall. Few mills of these proportions have been so extensively renovated. Because of its rural location, commercial use was not a viable alternative for reuse. It will be interesting to see if the developer can fill the space and make the project profitable. If it works, it may become a model for reuse of other mills along rural sections of the Blackstone River. Ashton Mill - Ashton Mill is another enormous complex, but has not been refurbished. This mill also scored very high in terms of its reuse potential. A landmark itself, the mill boasts a tall black smokestack which can be seen from miles away.

The outward appearance of the mill is sufficient to think that it functions as industrial space in the town of Cumberland. On visiting the site no activity, and little evidence of recent operation, was noticed. Ashton Mill's location in a suburban community without easy access to population centers reduces its potential for use as a resource for commercial space.

One of the mill's greatest attractions, from an historic perspective, is the nearly complete village of mill 
housing across the street. More than a score of brick multi-family tenements survive intact. This could make the Ashton site a possible location for a major renovation project to restore the mill complex and adjacent village to original condition. This researcher has not seen a more complete representation of life in a mill town anywhere else in Rhode Island.

Berkeley Mill - Berkeley Mill is a handsome structure with the added attraction of a compact mill village located nearby. The four-story structure is a simplified Italianate style. The large single tower has a medieval motif. This mill achieved a median overall score, being strong in physical features, but having poor location for economically viable reuse.

Lonsdale Mill complex - Lonsdale Mill was given an uppermedian score relative to other mills. The complex of at least 12 buildings houses a variety of industrial uses, office space, and one retail outlet for textile products. The complex should be considered an asset to the Town of Lincoln. Many of the buildings have been allowed to fall into a state of disrepair, and should not be allowed to deteriorate further. Some of the least maintained buildings are currently being used for industrial storage purposes, and it appears that the owners plan to discard them when they are no longer functional.

Lonsdale Mill is surrounded by a water diversion and 
storage network which was crucial to its success in the water-power era. Many raceways survive, along with a section of the Blackstone Canal.22 The feeling of this author is that the Town of Lincoln should pursue purchasing the area for public use while many of the structures remain in good condition. The few buildings in the complex which have been renovated prove that the site could be a visually pleasing historic resource while still providing revenue to the Town.

Ann \& Hope Mill - This mill got a moderately low score. It is a large building in good physical condition, but lacks the necessary historic qualities to receive a high rating. It currently serves as a discount store and warehouse. The mill's size and location make it a viable option for reuse as retail space with housing in the upper stories. The success of the limited retail activity currently being conducted suggest that the mill could become a central shopping area if it were refurbished and marketed correctly. Valley Falls Company - This mill was in a terrible state of disrepair in the late 1970's: windows were smashed, the roof was partially caved in, and the entire area was overgrown. Today the old mill is restored to pristine condition and serves as elderly housing. Most of the old raceways have been retained, adding to the historic feeling of the

22 Gary Kulik and Julia C. Bonham. Rhode Island: An Inventory of Historic Engineering and Industrial Sites. P. 102. 
grounds. Valley Falls Mill is a success story in the renovation of obsolete textile mills into useful elements of a community.

Rennedy/Stafford Mill - Stafford Mill is an older mill in an industrial zone which includes Pawtucket Thread Manufacturing, central Falls woolen, Pawtucket Hair cloth, and the Royal Weaving Mill. Directly across the river is Green \& Daniels Mill. This conglomeration of historic industrial buildings could form the core of a major preservation project in Central Falls. A small scale renovation of stafford $\mathrm{Mill}$ is being conducted at present by a private consultant.

stafford Mill is a rather small brick mill with beautiful granite openings and simple architecture. Its original use was for the manufacture of iron products; it was converted to a textile mill by Jenckes sons in the early 19th century. The mill scored an upper median mark in the evaluation. One key historic element is the old Lshaped dam which was built to provide power exclusively for stafford Mill. The small size and human-scale dimensions of the mill make it an attractive option for reuse as office space.

Pawtucket Thread Manufacturing Company - This old stone building cannot be seen from the road. Its rubble-stone walls reveal the early history of textile production in Central Falls, once one of the worlds largest producers. 
The building is small, only $78^{\prime} \times 4^{\prime}$, but is four stories tall. This small building could be converted into office space or another use which utilized its view of the river. Since Green \& Daniels across the river has been renovated, the view from Pawtucket Thread has been improved. Central Falls woolen Company - scoring very low in this study, Central Falls woolen Mill has had its facade altered by 20 th century additions. The canal from which it and other mills in the vicinity drew power, has been filled. In sum, much of the historic value of the mill has been destroyed over time. The size and apparently good condition of the structure suggest that reuse is a still viable alternative. This mill does not have the historic value of other mills, though in the context of its surroundings, it could be part an area redevelopment scheme. Pawtucket Hair Cloth Mill - This mill is similar to Central Falls woolen Company in that its historic elements and architecture have been ignored or altered. Elaborate cornices below the roof line are still visible on all sides of the building. The stair tower with overstated features still appears structurally sound, though lower windows have been covered over with brick.

Once a magnificent building, the mill is situated at the intersection of two well-travelled streets. Adequate parking could be a problem in any reuse plan, as there is minimal space currently available, and little unused land in 
the area. Another detractor from modern industrial use of this mill is the narrowness of the streets which abut the mill. This factor makes it difficult to maneuver large trucks to the industrial site.

Royal Weaving Mill - Royal Weaving Mill is one of the least valuable mills on the list. The mill is not very old, and has few features which are worthy of preservation efforts. Though vacant at present, the mill should probably be kept in industrial use which will most benefit the city of Central Falls.

Green \& Daniels Manufacturing Company - An enormous mill located just off Route 95 in Pawtucket, it was recently converted to office/condominiums. Space is still available in the complex. Tasteful redesign of the roof and windows has captured the "history of the place" while creating a usable space for modern needs. Hopefully, Green \& Daniels is the first of a succession of mills in the immediate area to undergo renovation.

Lebanon Mill - Detached from the mills in Central Falls, Lebanon mill is located just upstream of slater Mill. A typical turn-of-the-century industrial building, it towers five stories above the edge of the Blackstone River. The large floor area of this building in Pawtucket's busy downtown suggest the possibility of a retail market which would attract pedestrians in the city. The mill is directly across the river from Pawtucket City Hall, so it has a high- 
profile location which could be used to attract customers. The building does not appear to be fully occupied at present.

Old slater and wilkinson Mills - slater and Wilkinson Mills are nationally recognized historic sites. Both have been renovated and are used as museums of the textile industry. It is assumed that these sites have reached their fullest potential for modern reuse. 
CHAPTER 5, PROBLEMS A88OCIATED NITH OLD MILL8

Before old textile mills can be successfully reused, a number of obstacles must be overcome. Obsolete design features put older structures at a market disadvantage. Most industrial and commercial businesses find it cheaper and easier to build a new building than revamp a discarded structure.

Local government can play an important role in creating incentives or impediments to the reuse of mill resources. Cooperation of a pro-active local body is necessary to enhance established industrial areas as much as possible. In the space below, the author described some of the most common problems which undermine the economic viability of old industrial sites.

\section{Infrastructure imitations}

Adequate provision of sewer, water, and electricity are essential to industrial users. Technological progress has changed industry's infrastructure requirements. Often, the existing utilities do not meet modern needs.

Many older mills have on-site waste treatment. These plants are expensive to operate; Department of Environmental Management requires periodic self-monitoring which burdens mill operators, and must be passed to tenants in the form of higher rents. In the past, industry has released its waste untreated into the Blackstone River. The Blackstone was 
considered one of the most polluted rivers in the nation. ${ }^{23}$ Municipal sewers are an option which would free industry from the time and expense of maintaining adequate sewer treatment.

Electricity is readily available in all mills, but antiquated wiring is often insufficient for modern usage. Uses which demand large quantities of electricity must bear the cost of replacing electrical systems, where a newer industrial space might accommodate the use with little modification.

\section{Wooden I I00Is}

The higher degree of precision required by modern industry requires a flat, stable floor surface. The wooden floors of many mills, though structurally strong, are not adequate for machining and other industrial operations.

\section{Use of upper stories}

Because the upper floors cannot accommodate some types of industrial use, they are best used for warehousing or a non-industrial use. This usually decreases the per square foot rent value at which the space can be marketed. Also, businesses prefer to be located on the ground level to eliminate the time and expense of freight elevators.

\section{High maintenance cost}

The costs of maintaining old textile mills can be

23 Save the Bay. Special Report: Bring Back the Blackstone. P. 4. This document contains an excellent description of the sources and types of pollution in the watershed. 
exorbitant. Plumbing and heating apparatus, often near the end of its usable life, needs constant care. Replacing a roof can easily be a six-figure repair. 24 Annual costs for heat are very high in mills with lots of window area, high ceilings, and little insulation.

\section{Highway access}

Another problem with old mill sites is that they are seldom have adequate highway access. Transportation routes in the mill era were very different from modern routes. simple, direct highway access is a primary consideration of modern business. This is an obstacle in which a town could cooperate with the mill owner to bear the cost of road improvements to facilitate economic development.

\section{yixing of uses}

Large-scale manufacturing has been moving south at least since the early 1900s. In order to fill vacant industrial space, mill owners try to attract a number of smaller tenants. This is a good strategy, but can lead to problems of adjacent uses being incompatible with each other. Noisy and noxious users must be consolidated away from users who desire a quiet business atmosphere. Mixing of basic types of uses can create worse problems. Separation of uses is an accepted planning

24 According to Armen Harootian, the roof of the Blackstone Mill will cost $\$ 250,000$ to $\mathrm{fix}$. The repair is needed, but is difficult to justify economically, given the revenues being generated by the space. 
principle. Industrial uses should not be mixed with nonindustrial uses, except in rare cases. ${ }^{25}$ The mixing of commercial and residential uses can be accomplished through careful planning. Mill complexes with a number of buildings can be designed to offer a variety of compatible land uses. zoning

With good reason, local zoning has placed all mills in this study in industrial zones. Economically viable reuse of the mills often means changing the use to non-industrial. This requires a zone change, a sometimes difficult, often time consuming prospect. Each town must assess the need for non-industrial options and create policy which will keep the mills in use.

Many towns have a strict list of allowable uses in each zoning district. This type of zoning enforcement tool can be restrictive, and does not allow for flexibility in the planning process. The use of industrial performance standards within industrial zones is a viable alternative which is receiving increased attention. Performance standards allow the property owner to establish any use he chooses as long as it does not exceed the limits of industrial outputs such as noise, smoke, glare, etc. The difficulty with performance standards is their enforcement.

25 A factory outlet for lace goods is located within the Lonsdale complex, and does not appear to cause any problems to other businesses. The building is, however, separate from structures which house industrial users. 
The problems which mill owners encounter are not insurmountable obstacles. Combined efforts of mill owners and local government officials can diminish their impact and keep the mills profitable. Local government must first assess each mill's value, and the willingness of local officials to aid in preservation efforts. The next step is to develop policies which will counteract the mills' disadvantage in the market. 


\section{CHAPTER 6, REUSE OPTIONS}

In recent years, there have been a number of successful projects which renovated industrial space for a different use. The elements which make a project successful vary with the individual site. Some mills have been completely redesigned, while others have simply been modernized to keep the building structurally sound.

The outcome of a successful renovation project is a mill building which has a useful purpose in the community while maintaining its historic character. Below is a description of some of the reuse projects along the Blackstone which appear to have been successful in achieving the desired outcome.

\section{Industrial}

Industrial use is included as a category in this section to show that an old mill can be renovated to continue to provide industrial space for the community. Many mills can still be viable for industrial use, and this is often their best and highest use.

Samoset Mill is a good example of the type of renovation that can be done to maintain an historic mill as industrial space. The mill has be refitted with modern windows which do not detract from historic features of the structure. Interior spaces have been realigned to make the mill operation smoother. Located in a low-density area in the flood plain, industrial use is compatible with the 
surrounding area. ${ }^{26}$

Commercial

Dividing a mill into a number of retail and office spaces is an alternative which has been used extensively in mill restoration. The general design is to keep retail at the street level, while encouraging a variety of non-retail commercial uses on the upper levels.

Lonsdale Mill complex, with a variety of building sizes and configurations, would be an excellent site on which to encourage commercial activity. The site already houses an office user and a factory outlet. It is in close proximity to a shopping district across the river. Ann Hope Mill, located nearby, is now a discount store, but is not used to its full capacity.

\section{Indoor recreation}

Indoor recreation is a good alternative for utilizing the large interior space of textile mills. The cold New England winter keeps most of the population indoors for a significant portion of the year. Businesses which could utilize mills for recreation include a health club, miniature golf, and roller skating.

At present, no mills in the study area have been converted into indoor recreation. However, an old office building adjacent to French Worsted Mill operates as an

26 Samoset and Nyanza Mills are protected from flooding by a high berm which was constructed along most of the northern Woonsocket section of the Blackstone. 
arcade and entertainment center, with apparent success. A high-volume traffic area is necessary to make this alternative viable.

Residential

Probably the most popular reuse option, a number of mills along the Blackstone River have been converted to residential use. These include Glenark Mill, Albion Mill, and Green \& Daniels Mill. Each mill has been put to a slightly different use. Glenark is a small mill converted into an apartment building in downtown woonsocket. Albion Mill is an enormous project which turned the mill into condominiums in a rural setting (page 83). Green \& Daniels Mill is a recent office/condominium conversion which is already $80 \%$ occupied. Each mill must be assessed in the context of its community to determine the type of housing needed.

\section{Elder care facility}

Valley Falls Mill in Central Falls has been renovated into a beautiful nursing home. The structure was in terrible condition before the renovation process began. Today the old mill has all new windows and doors. The front loading tower offers residents of each floor a place to sit and look out over the nearby neighborhood. A raceway between the two mill structures still allows water to flow through the site with bridges over it for access. The advantages of using of using a mill for elder housing is the 
cohesiveness and safety of a single building. Before and after photos of the mill prove that sufficient effort can restore nearly any mill structure (page 82 ).

\section{Other options}

Other options worthy of consideration as reuse alternatives include a medical care complex, educational facility, municipal office space, and even a minimumsecurity prison. A medical center design could convert an entire mill into a central facility in which patients could obtain a variety of services at a single location.

The option of converting an old mill into a school could be an attractive option for communities with changing educational needs. Large interior spaces found in many mills could be utilized as classroom space. Removable dividers could be used to design rooms as needed and be removed as needs change. Spaces could be transformed or closed off to alter the capacity of the school. Another advantage the mills hold in regard to this option is that many are centrally located in the community.

Municipalities could also use old mills to meet their requirements for office space and other local government functions. The size of a textile mill would permit a city of town to locate all of its departments under one roof, instead of spread around the community.

A final option this author will offer is converting a mill into a minimum security prison. The acreage of land 
attached to many mills is sufficient for all the functions of a prison facility. The size and layout of mill structures may lend themselves to partitioning into individual cells. The need for prison space in Rhode Island makes prison siting an option to consider. As part of a work program, inmates could be hired to perform construction, lowering the start-up costs. A large complex, such as the Blackstone Mill in North Smithfield, would probably be the most efficient location for such a project. The options addressed describe only a partial listing of the options for adaptive reuse of old textile mills. Altering the use of these industrial structures is intended to keep them in good repair and in full function. If only industrial uses are permitted exclusively, many mills will fall into disrepair and possibly become tax-delinquent municipal burdens. Ingenuity and vision are tools the planning professional must use in order to maintain continuity of use in declining industrial zones. 

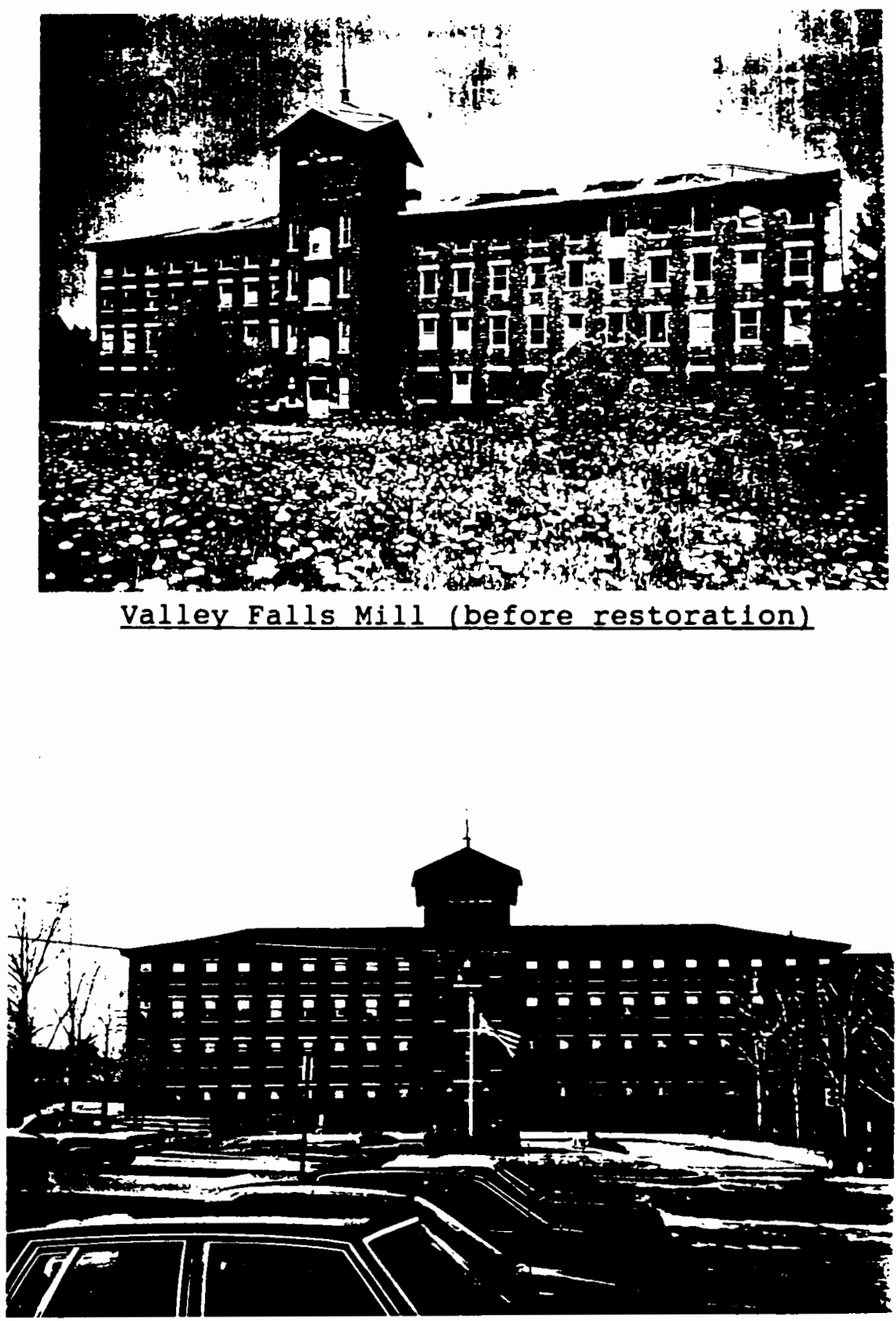

Valley Falls Mill (Restored) 


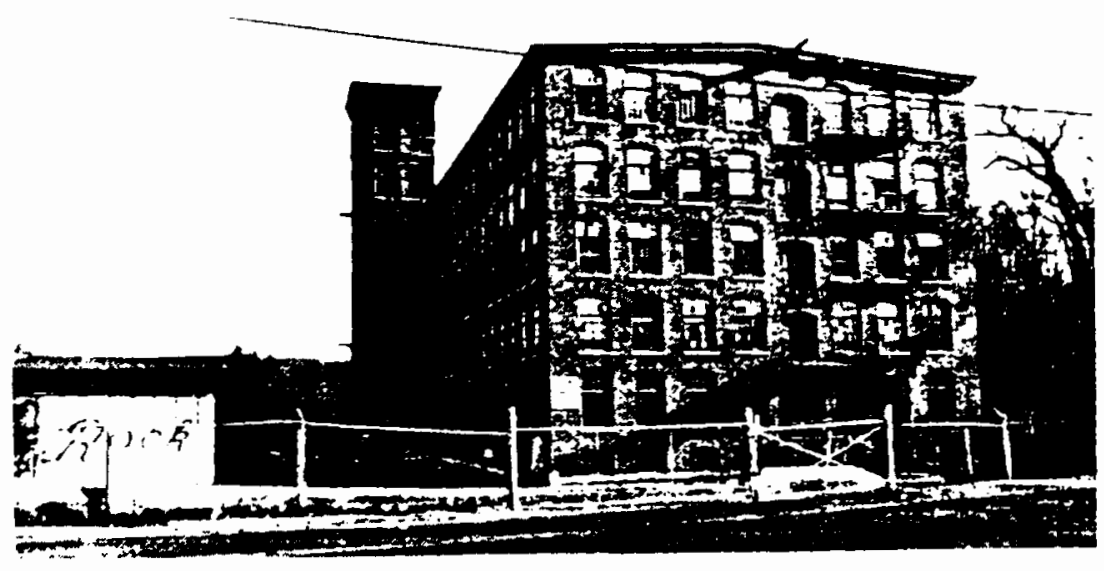

Albion Mill (before restoration)

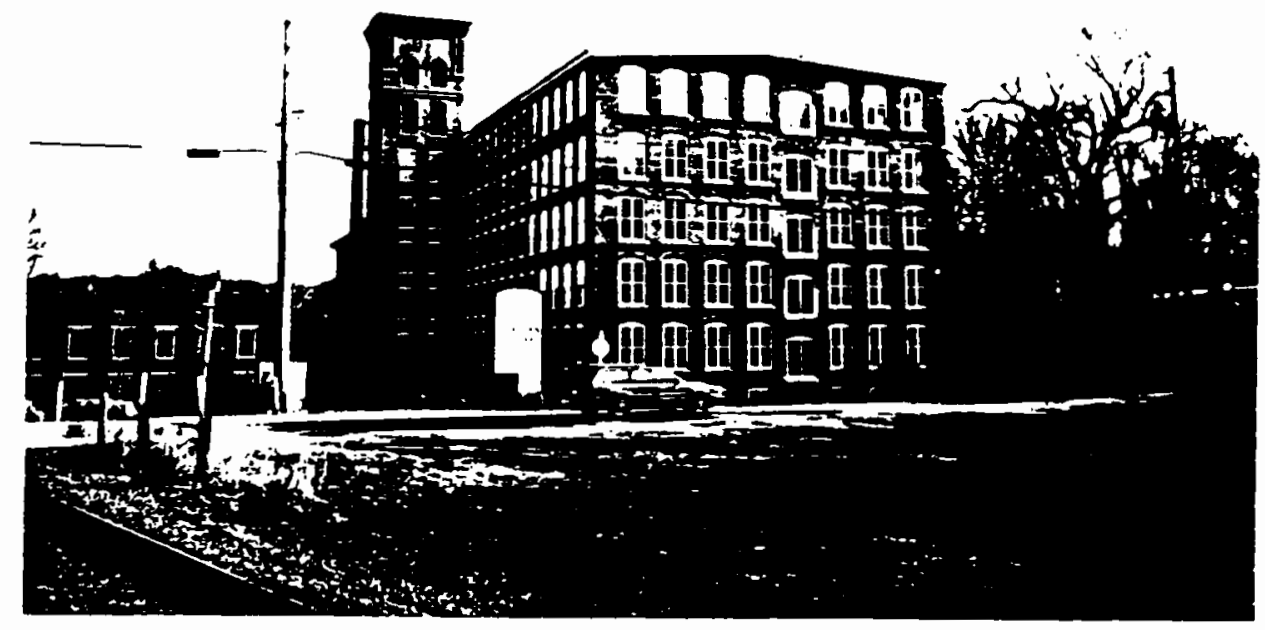

Albion Mill (restored) 
CHAPTER 7, GOVERMMENT PROGRAMS

While some historic industrial sites are economically feasible renovation projects, others are not. To fill the gap between a marginal project and a profitable one, a number of government programs exist. Below is a brief description of some of the most common forms of federal, state, and local government policies which aid the cause of historic preservation.

\section{Federal aid for historic preservation}

National Heritage Corridor Commission - The Commission is committed to revitalizing the Blackstone River valley. The Valley is federally recognized for its historic significance as well as its cultural artifacts and settings. The National Park Service currently runs historic visits to many of the most significant sites in the corridor. As more NPS personnel are assigned to the Uxbridge office, the staff will provide planning assistance, management, and interpretation of the area. Grant institutions

Federal and state matching grants for restoration and planning projects are available on an annual basis. To date, nearly $\$ 5$ million in grants have been awarded statewide. Contact the Rhode Island Historic Preservation Commission for more information. Federal tax incentives

The powerful Economic Recovery Tax Act of 1981 created 
an enormous incentive for historic rehabilitation. Rehab projects could take a 258 tax credit on preservation project. The tax credit has recently been changed to $20 \% .27$ The credit is a major reason for the recent boom in historic preservation. Elimination of this tax credit was considered in 1986, as it reduced a considerable portion of federal tax revenues. It would be wise for owners of historic textile mills to act quickly to take advantage of the tax credit.

Application for the credit is made through the Rhode Island Historic Preservation Commission. Final certifications are issued by the National Park Service.

\section{state programs}

Rhode Island Historic Preservation Commission administers state Income Tax Incentives, but they are presently only available for owner-occupied historic homes. RIHPC also administers most other federal funds for historic preservation, and has information on tax incentives for income-producing properties. 28

One mission of RIHPC is to provide professional advice on the care of buildings of historic value.

27 Colin, Thomas J. "A Historic Anniversary." Historic Preservation, May 1986, p.25.

28 RIHPC puts out a pamphlet which describes the potential for tax incentives in the preservation of income-producing properties. It is available at the old state House, 150 Benefit street, Providence. 
The State's greatest contribution to historic preservation takes the form of zoning enabling legislation. These mandates have given local governments power to enforce a variety of techniques to preserve Rhode Island's historic resources. Recently passed enabling legislation is being refined and may make provision for more programs than are listed in this document. Programs listed below under the heading of local programs are derived from legislation at the state level.

\section{Local Action}

Historic district zoning - Local historic districts are created by a community to help save historic buildings and to preserve a sense of time and place. Historic districting allows the community to control most exterior construction, alteration, or repair of structures within the zone. This method helps to preserve entire neighborhoods within a community, and can be developed as an overlay over the existing zoning ordinance.

$T D R$ - Transfer of Development Rights is a useful planning tool which can be applied to historic buildings. The development rights to an historic property can be sent to a receiving property, protecting an historic structure from development which would compromise the historic integrity of the site.

Property tax abatements - A diminution or elimination of property tax reduces the amount of revenue a mill owner must 
generate to make his property profitable. Tax abatements should be created with a limited time on the relief, and should be commensurate with the mill's historic benefit to the town. Tax abatement has the potential to become a major element of local efforts to preserve mill buildings. Commercial property which has historic value must be taxed at a lesser rate coupled with assurance from the owner that the property will be adequately maintained. Infrastructure improvements - Another method by which local government can encourage profitable reuse of old mills is by updating surrounding infrastructure to meet the needs of modern industry. Industrial property must be kept economically viable or the physical structure will not be maintained. By providing for sewer, water, and power needs towns can help make old mills more desirable locations for attracting new business.

Revolving funds - A preservationist tool since the 1950's, revolving funds remain an effective tool in accomplishing preservation at the local level. Purchase, rehabilitation, resale, or acquisition and sale are contingent upon restoration of the property. 29 A real estate transfers tax can be used to generate funding to support individual restoration projects. Easements - Easements are another means used to preserve

29 Advisory Council on Historic Preservation. 1988. Supplemental Reader: Introduction to Federal Projects and Historic Preservation Law. P. 40. 
historic properties. A common type of easement prohibits the owner from altering the property without approval of the local historic board. Easements can be used to protect buildings, grounds, or entire sites. Legislation created in 1976 allows income tax deductions for charitable contributions of easements on "historically important land areas and structures." 30

zoning changes - Many old mills are currently zoned for manufacturing uses, to the exclusion of other viable uses. In addition, some of the mills are located in areas which are suitable for and surrounded by residential and commercial uses. It is the responsibility of each community to review and amend its zoning for the overall community benefit. Allowing mill owners flexibility in the range of allowable uses creates an atmosphere which encourages adaptive reuse of obsolete industrial buildings.

30 Tax Reform Act of 1976. Advisory Council on Historic Preservation. 1988. Supplemental Reader: Introduction to Federal Projects and Historic Preservation Law. P. 40. 
CHAPTER 8, GUMMARY

Many of the mills which scored highest in this study have already been renovated for adaptive reuse. The mill structures listed below have been fully renovated:

Score

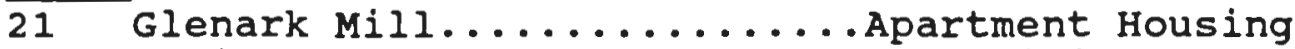

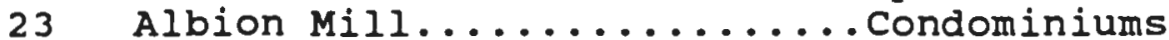

22 Valley Falls Mill............ Elderly Care Housing

20 Green \& Daniels Mill......... Office/Condominiums

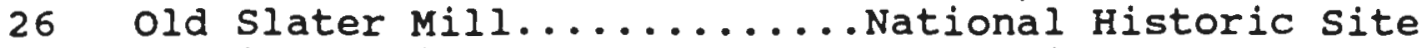

26 Wilkinson Mill............. Industrial Museum

These six mills serve as examples of the potential for adaptive reuse of textile mills.

Samoset Mill in Woonsocket has been partially renovated, but maintains its original industrial use. This mill is a good example of the type of renovation which can be performed on an industrial structure which will continue in industrial use.

of the twenty-two unrestored mills in the study area, five rated very high for their reuse potential. These structures should be given priority for renovation, as they exhibit a variety of characteristics which make them viable sites. They are, in order of relative value:

\section{Score}

26 Slatersville Mill, North Smithfield

24 Harris Mill \#2, Woonsocket

24 Bernon Mill, Woonsocket (one building renovated)

24 Ashton Mill, Cumberland

23 Falls Yarn Mill, Woonsocket

The slatersville Mill ranks as the best option for adaptive reuse of any mill in this study. Besides the mill, the complex contains a large stone warehouse, a large turn- 
of-the-century industrial building, a very old office building, a powerhouse, and various smaller structures. In addition, the original raceway remains intact and still passes water through the site.

Put in its village perspective, slatersville Mill takes on more historic value. Two large stone office buildings are situated in the village up the hill from the mill; many mill worker houses survive; a stone-arch bridge dating back to 1855 crosses the Branch River immediately north of the mill; a series of reservoirs from the water-power era remain upstream of the mill site. The historic significance of slatersville was such that it has been designated a National Register Historic District.

Two other village areas have a conglomeration of historic elements from the textile era. The woonsocket riverfront contains a number of historic mill structures in close proximity to each other. This would be an ideal area for an economic development initiative to reuse the existing buildings to accentuate Woonsocket's industrial origins. In 1989, the City received a master plan for redesign of the urban waterfront. ${ }^{31}$ The waterfront plan could help revitalize the City's downtown.

The other area with a significant number of old textile mills is the conglomeration of mill sites at central Falls.

31 Albert Veri \& Associates, Inc. 1989. Historic Blackstone Riverfront, Master PIan. Providence, RI. 
This area contains stafford Mill, Pawtucket Thread, Central Falls Woolen, Pawtucket Hair Cloth, and River Spinning Company. None of the structures has been renovated, though all appear to be structurally sound. Across the river in Pawtucket stands Green \& Daniels, completely renovated for a new use. The City of Central Falls should work to use this area to its advantage as a visual reminder of its proud industrial past.

All the mills which are listed in this study have some historic value. Even those which ranked at the bottom of the scoring should be considered for their individual assets and the types of use for which the old structures may be suitable. Each mill has problems and potentials which must be addressed in order to determine its value as part of an overall revitalization scheme for the Blackstone valley. The National Heritage Corridor Commission can help to coordinate communications between mill owners and government agencies to bring about economic reuse of textile mills in a manner that is sensitive to their historic value.

\section{Concluding Remarks}

This study represents an attempt to qualify the relative values of old textile mills for adaptive reuse. Reuse often means a different type of use for the structure, including modern industrial uses. It is this researcher's opinion that there is a single best option for reuse of each mill. The evaluation categories used in this study, as well 
as site-specific location and market factors, should be analyzed to ascertain whether the mill is best used for industrial, commercial, residential, or mixed use. Determining best use requires further study to better address market factors.

Some mills are relatively easy to assess. Slatersville Mill in North Smithfield, for example, is a great location for mixed use office/ retail, with the possibility of some residential space. Its location in the old mill village is a relatively high traffic area in North Smithfield. Furthermore, North Smithfield lacks many of the commercial amenities, forcing residents to shop elsewhere. slatersville is an ideal location for economic revitalization efforts.

Assessing the reuse potential of other mills can be more difficult. Large complexes such as the Ashton mill in Cumberland may not be in a location which could support its adaptive reuse. The needs for new commercial or residential space must be carefully considered before a renovation plan is conceived.

Renovation cost is another key factor in the adaptive reuse formula. This study did not attempt to quantify costs of renovation for obsolete structures. Ideally, the costs per square foot for purchase and renovation of an old mill should be less than the cost of new construction. In cases where reuse would not be profitable in the marketplace, 
government incentives may fill the gap between anticipated costs and revenues.

Government intervention is necessary if mill resources in the Blackstone Valley are to be preserved. Local governments should play a major role in encouraging viable uses of mill structures. Allowing mills to become unoccupied and deteriorate could result in the mill becoming a burden to the town. ${ }^{32}$ It is the best interests of each community to ensure a business climate which will keep the mills economically profitable.

Communities in the study area must evaluate the impact of existing policies on mill resources. Historic structures are important components of a community's fabric. They help define a sense of place and educate residents on the historic context of their region. They have potential for economic development projects in the region. The social value and economic utility of old textile mills should be recognized and included as part of a revitalization plan for the whole Blackstone Valley.

32 If taxes on a mill structure cannot be paid by revenues generated, the property owner may elect to forfeit the property. This would force the municipal government to maintain the structure or demolish it. 
Appendix

Architectural features of textile mills
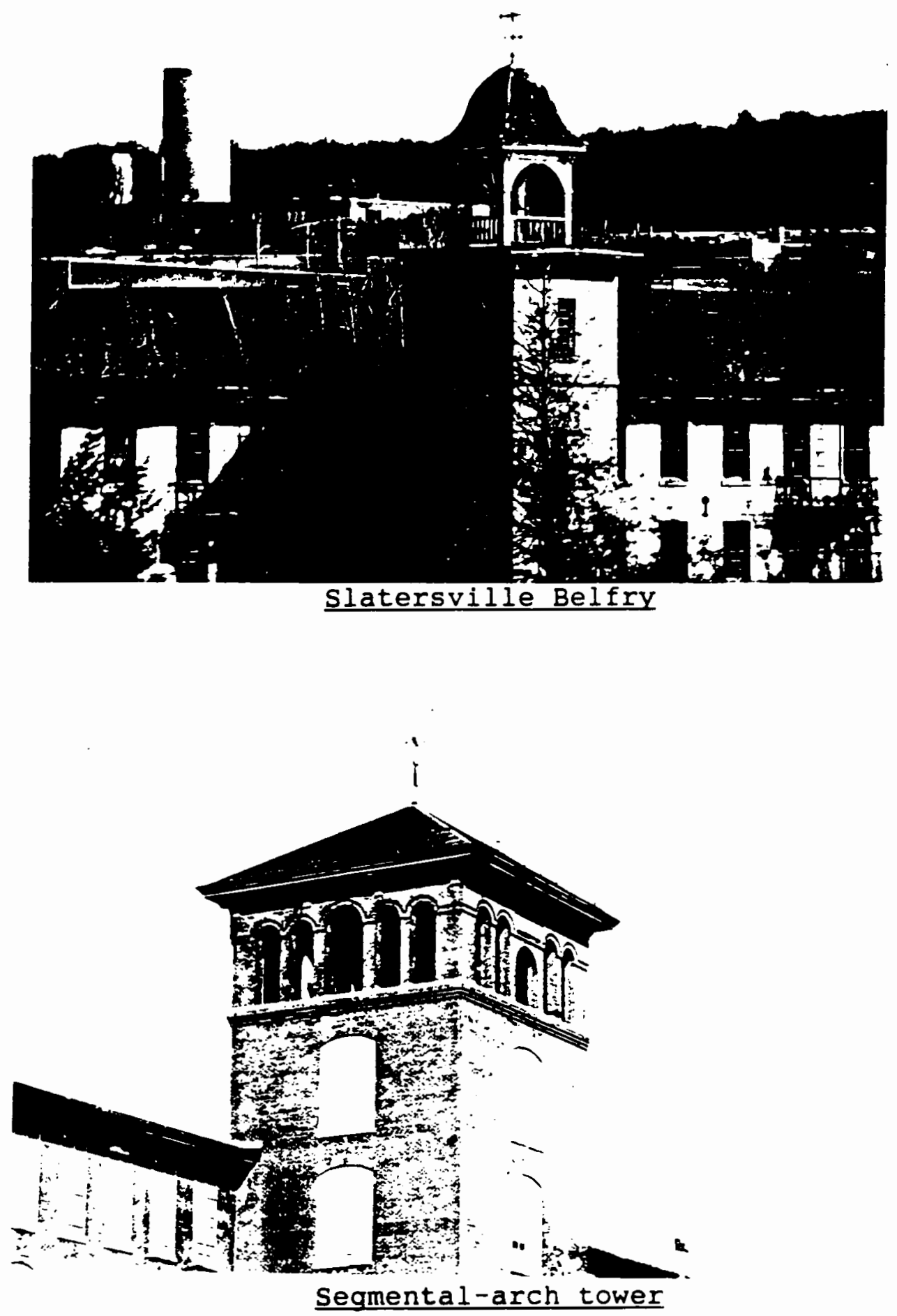

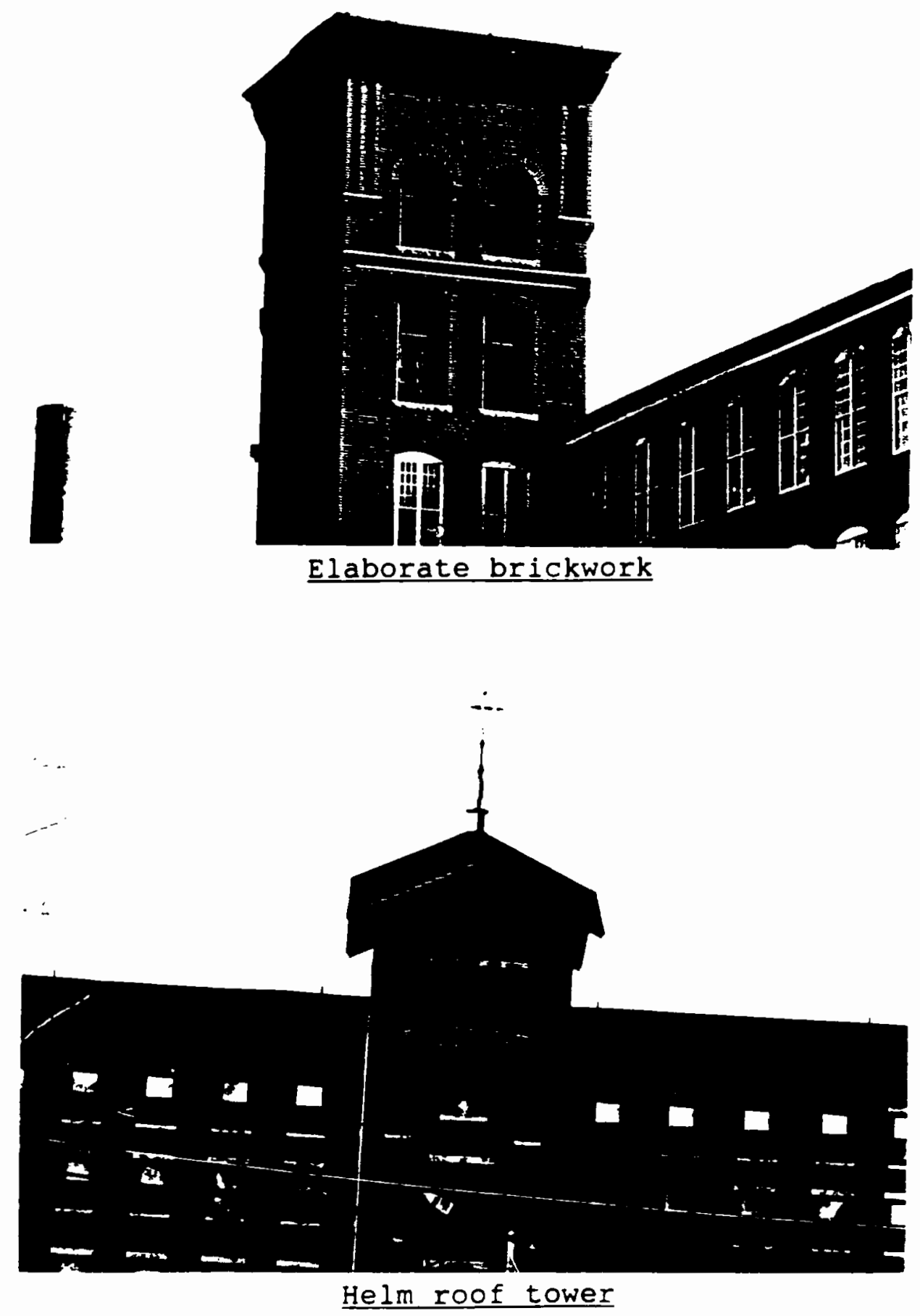

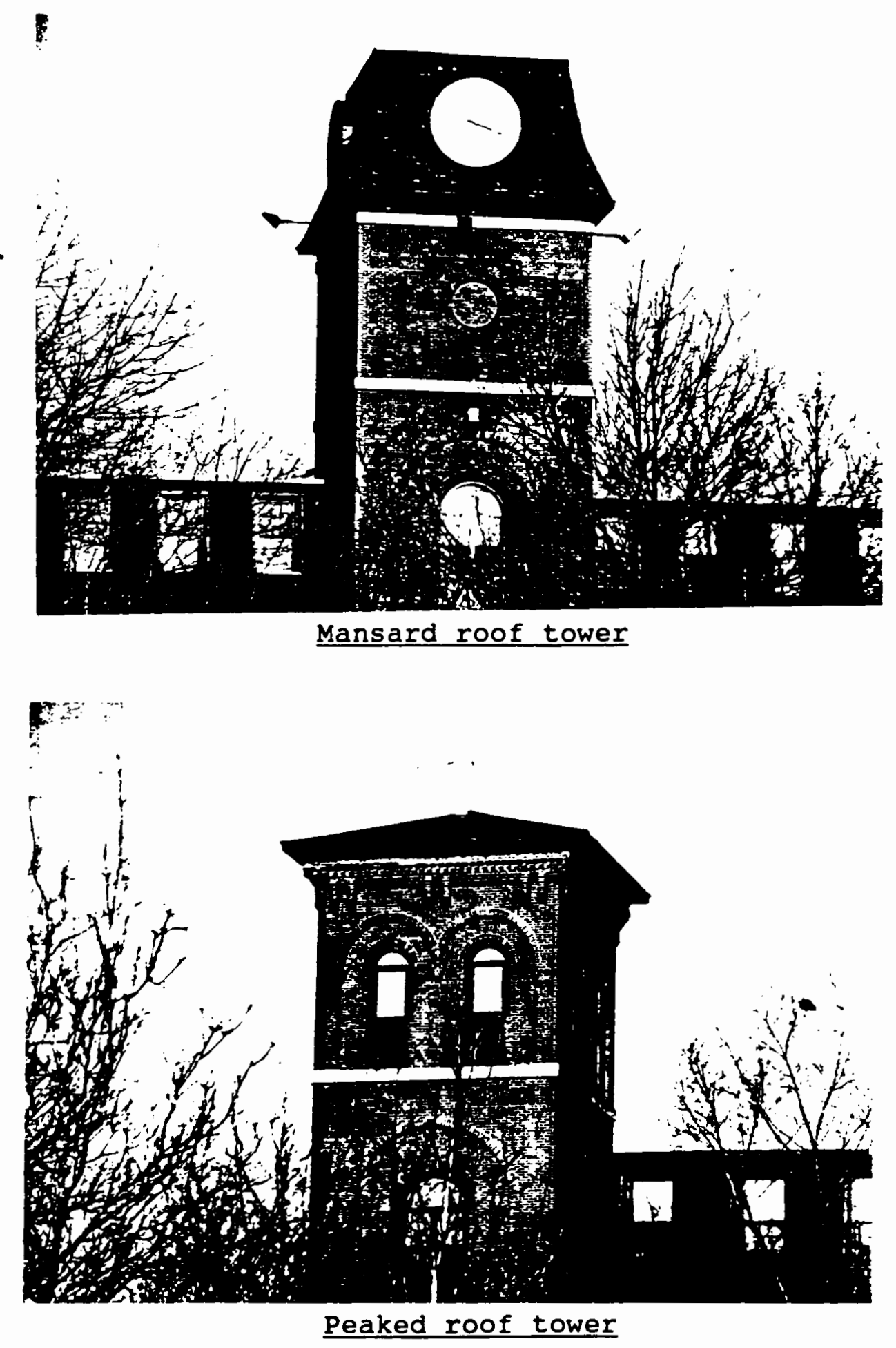


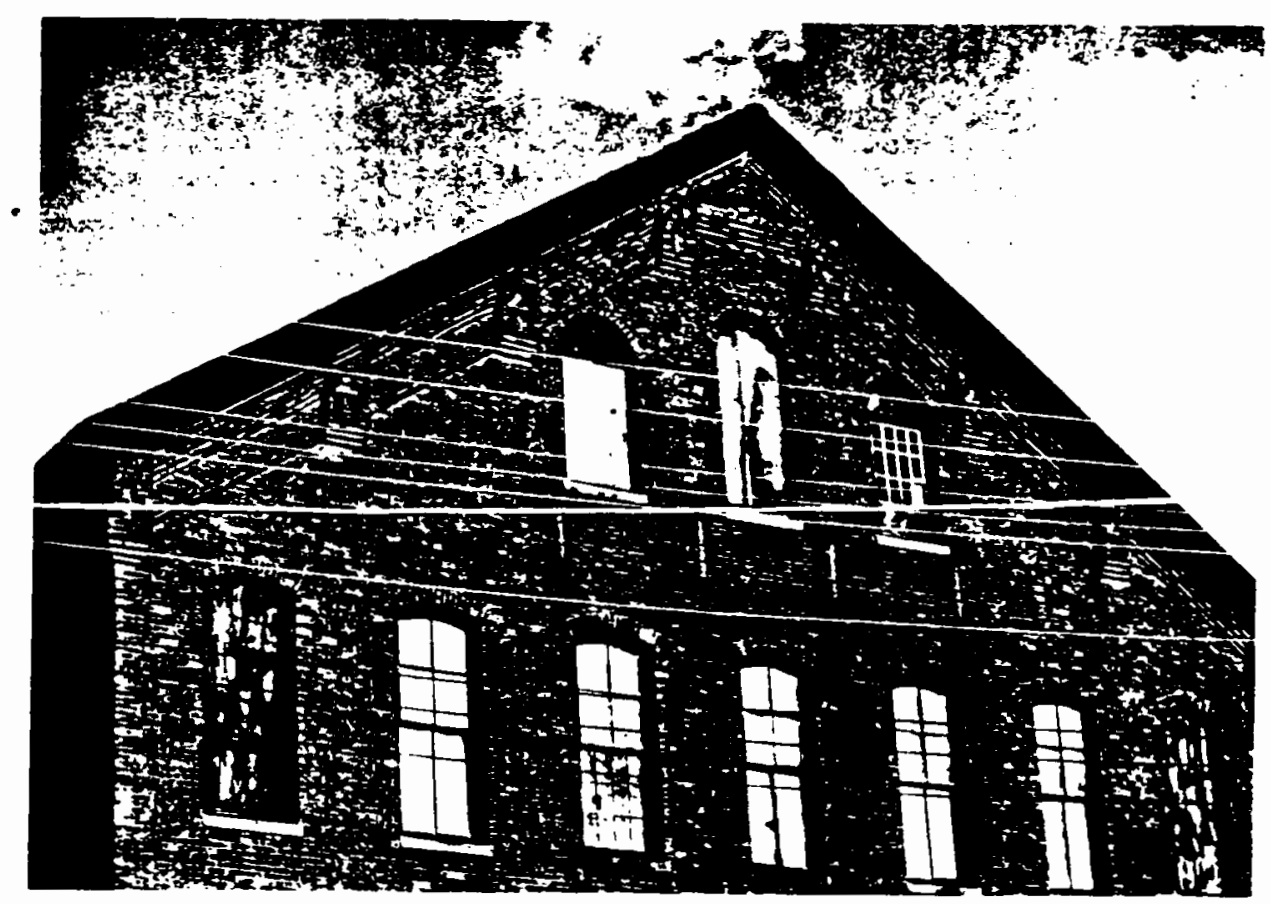

Gabled roof with brickwork

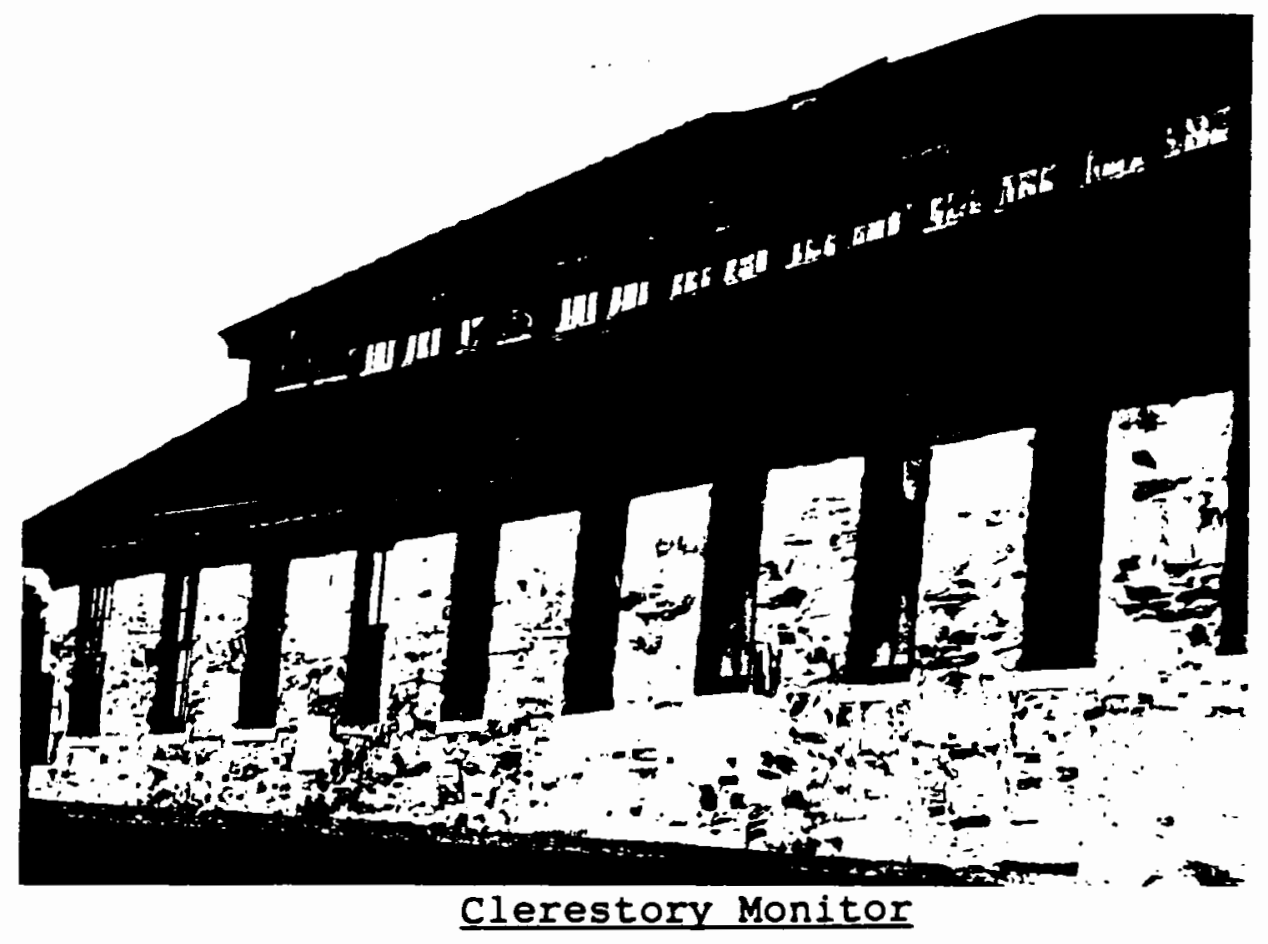



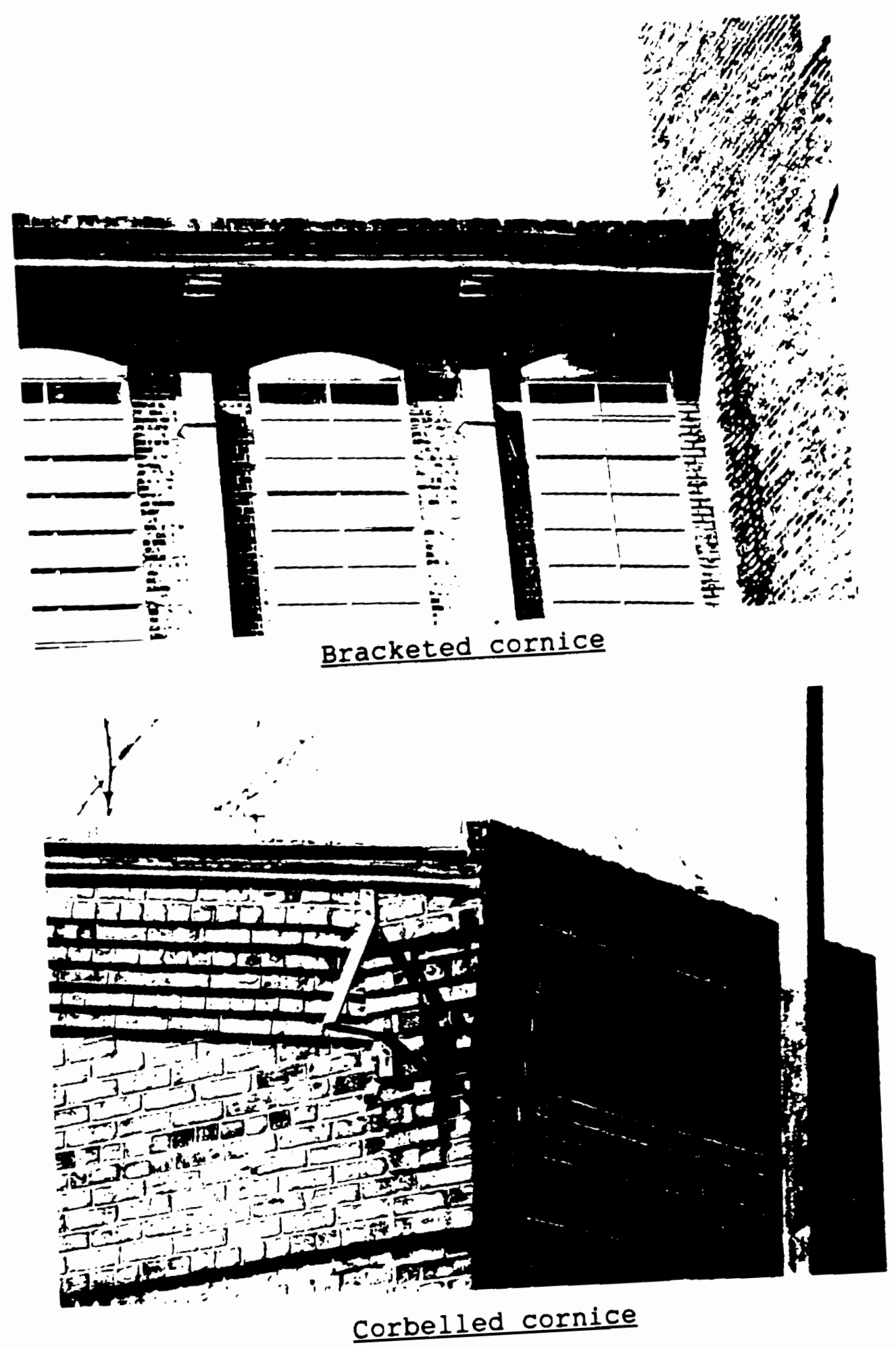


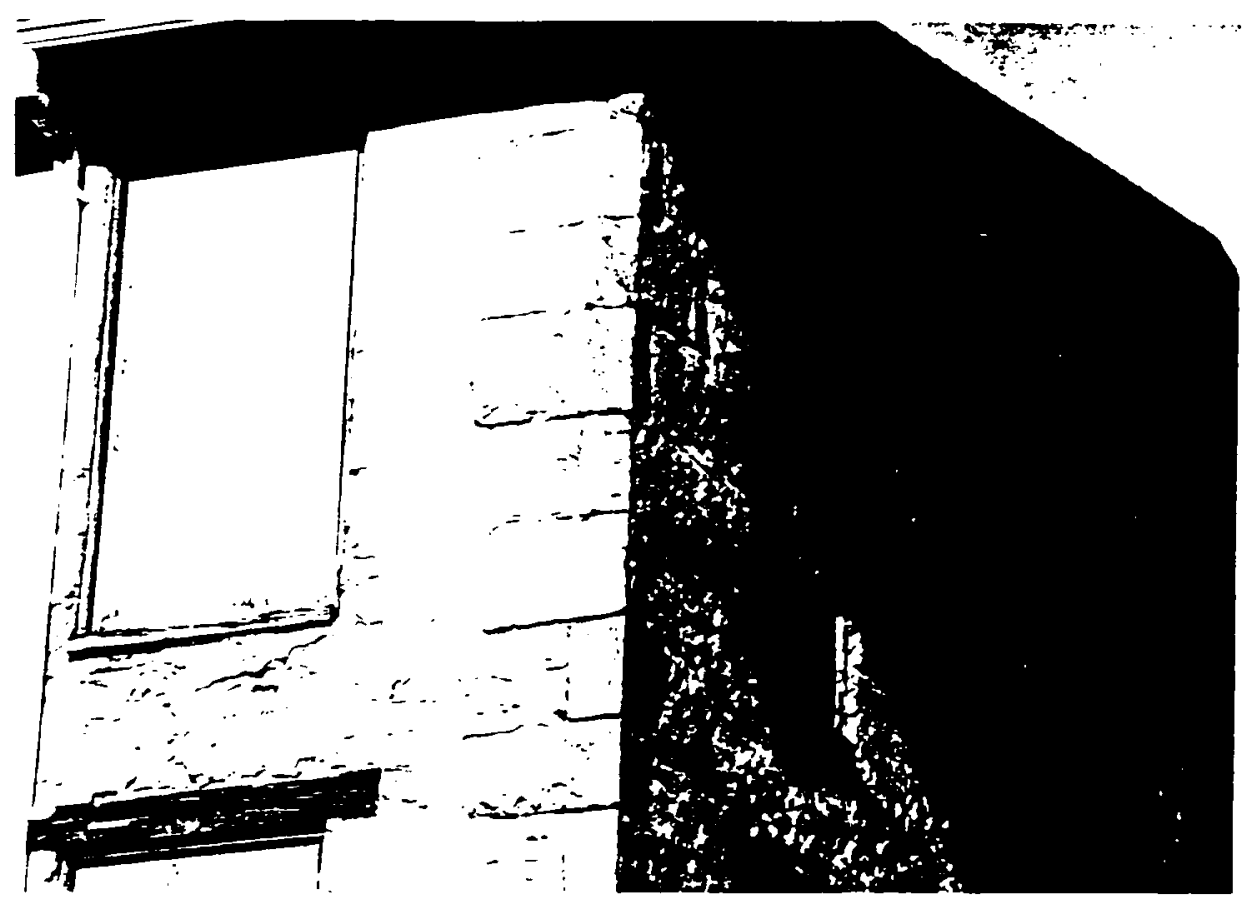

Quoined corner

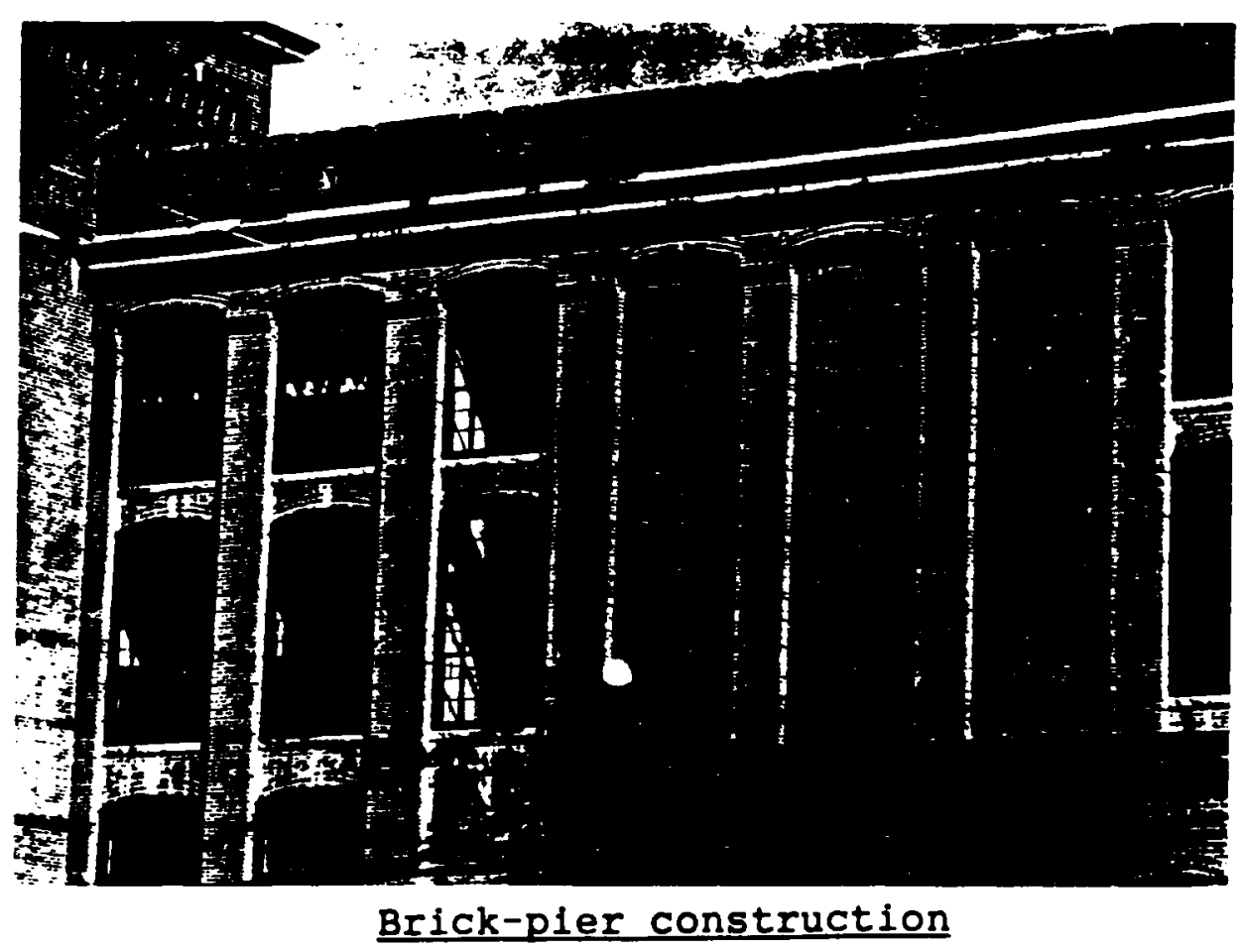



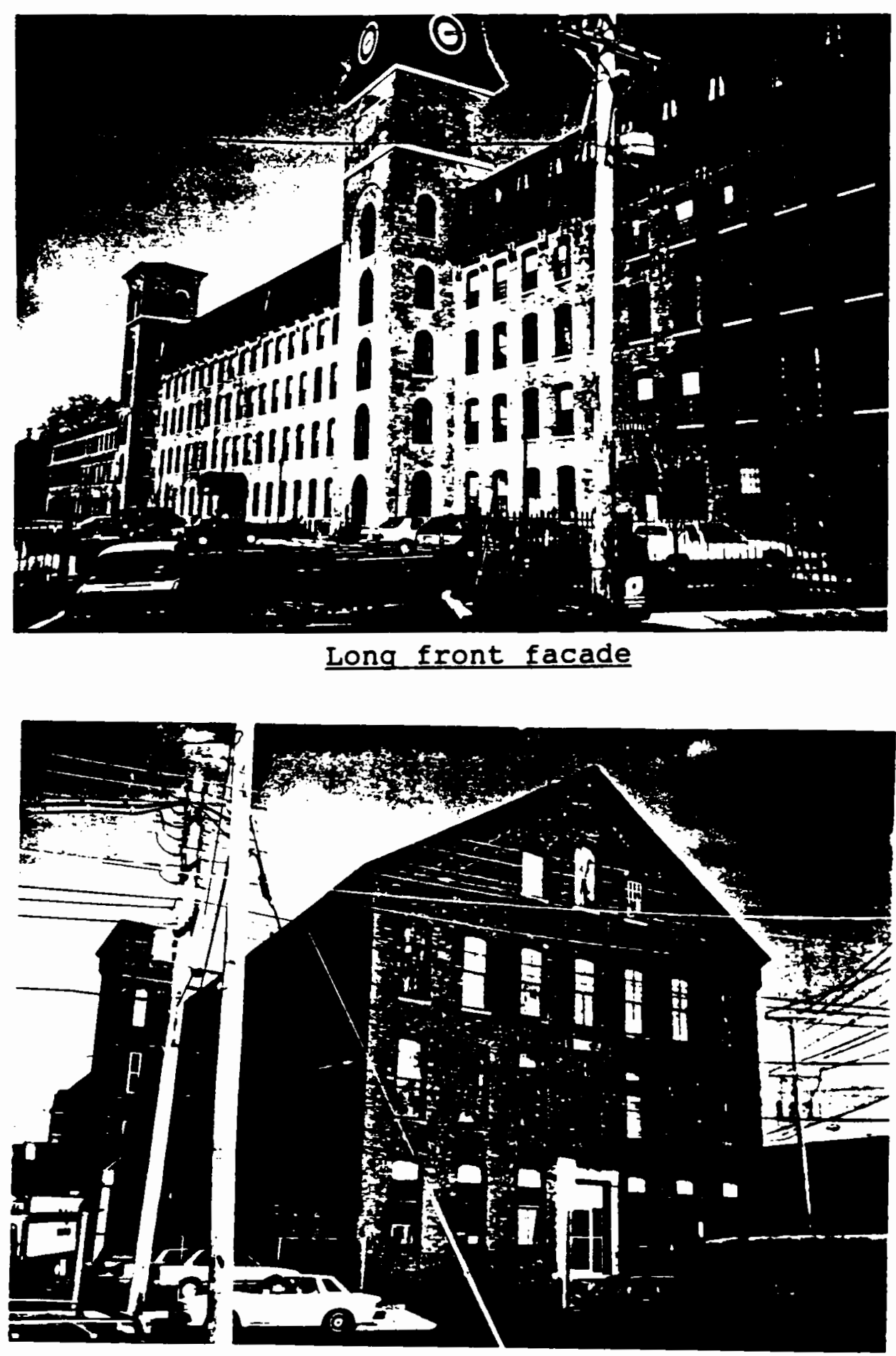

Gabled facade 


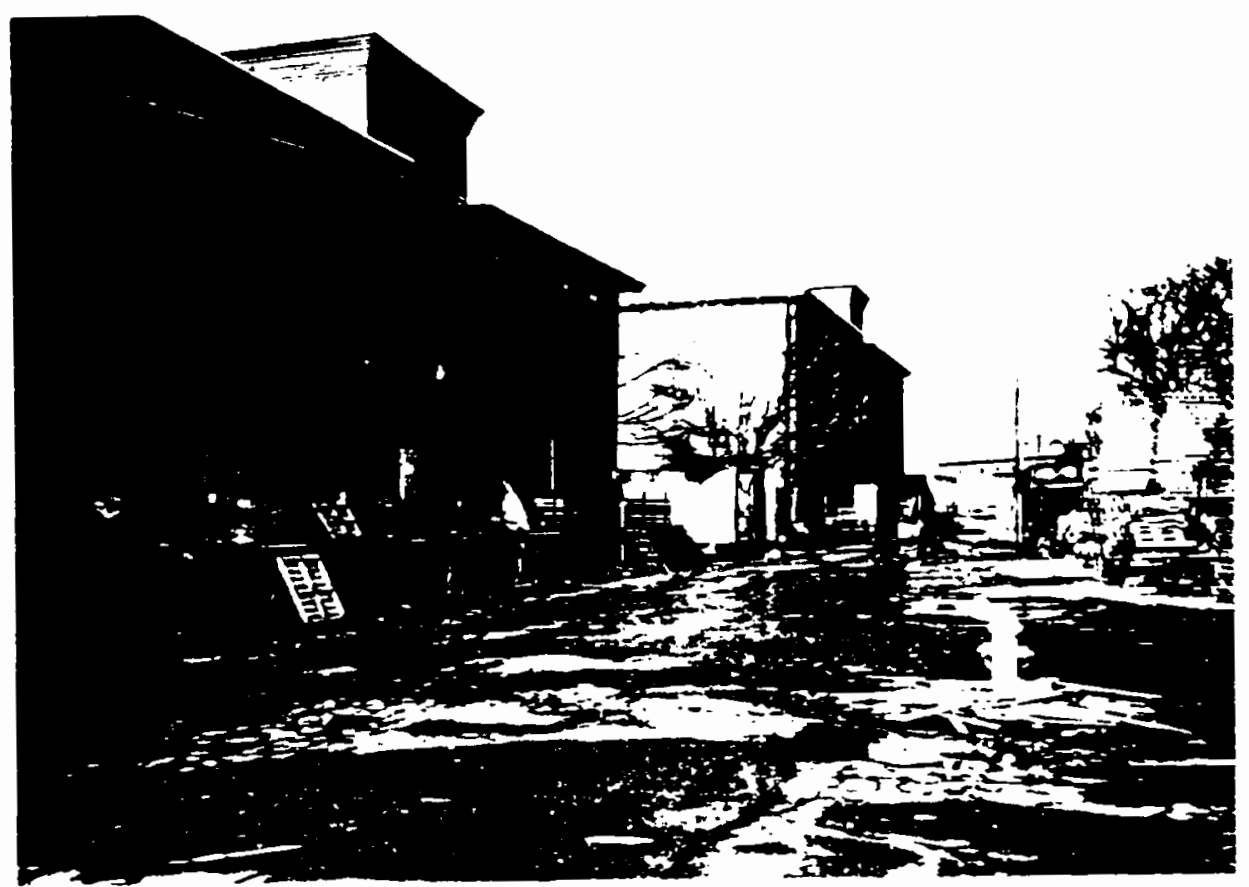

Early brick facade
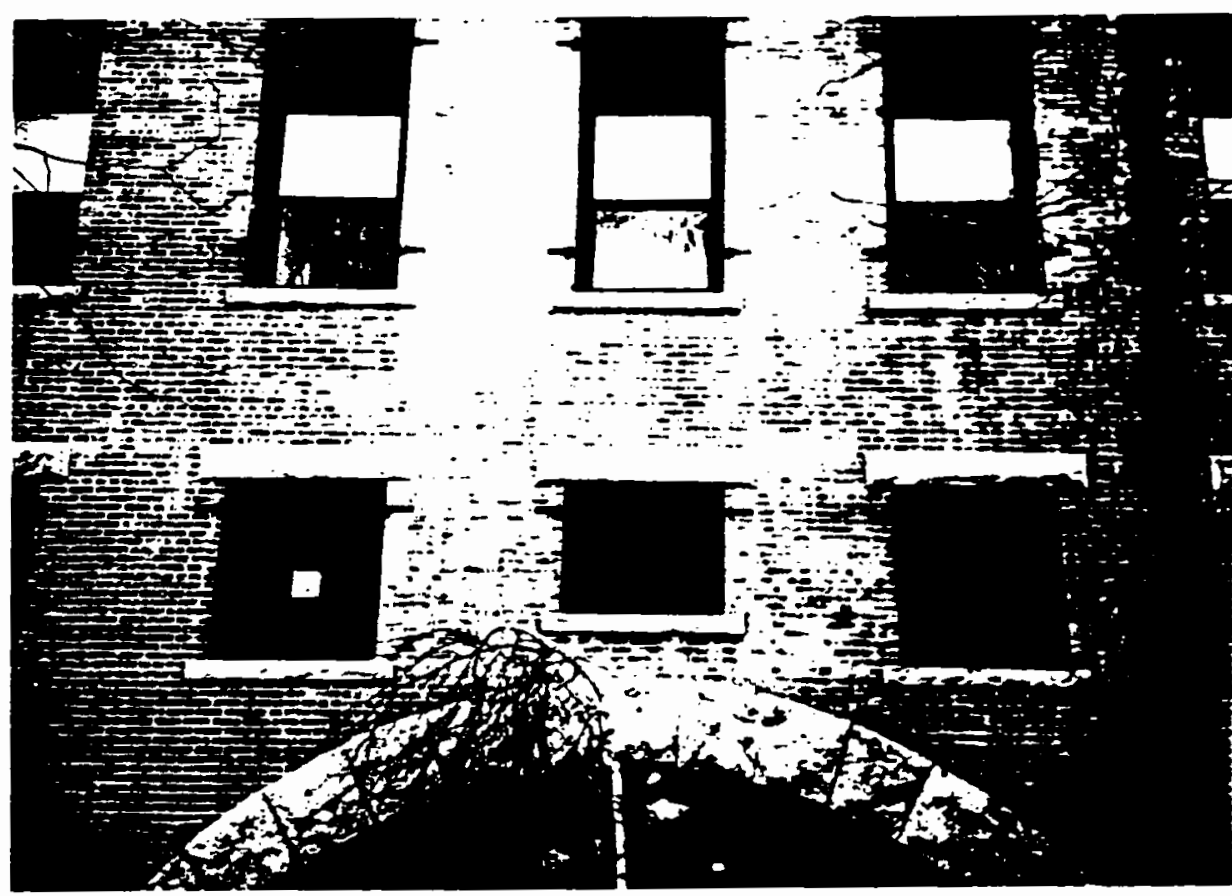

Replacement window design 


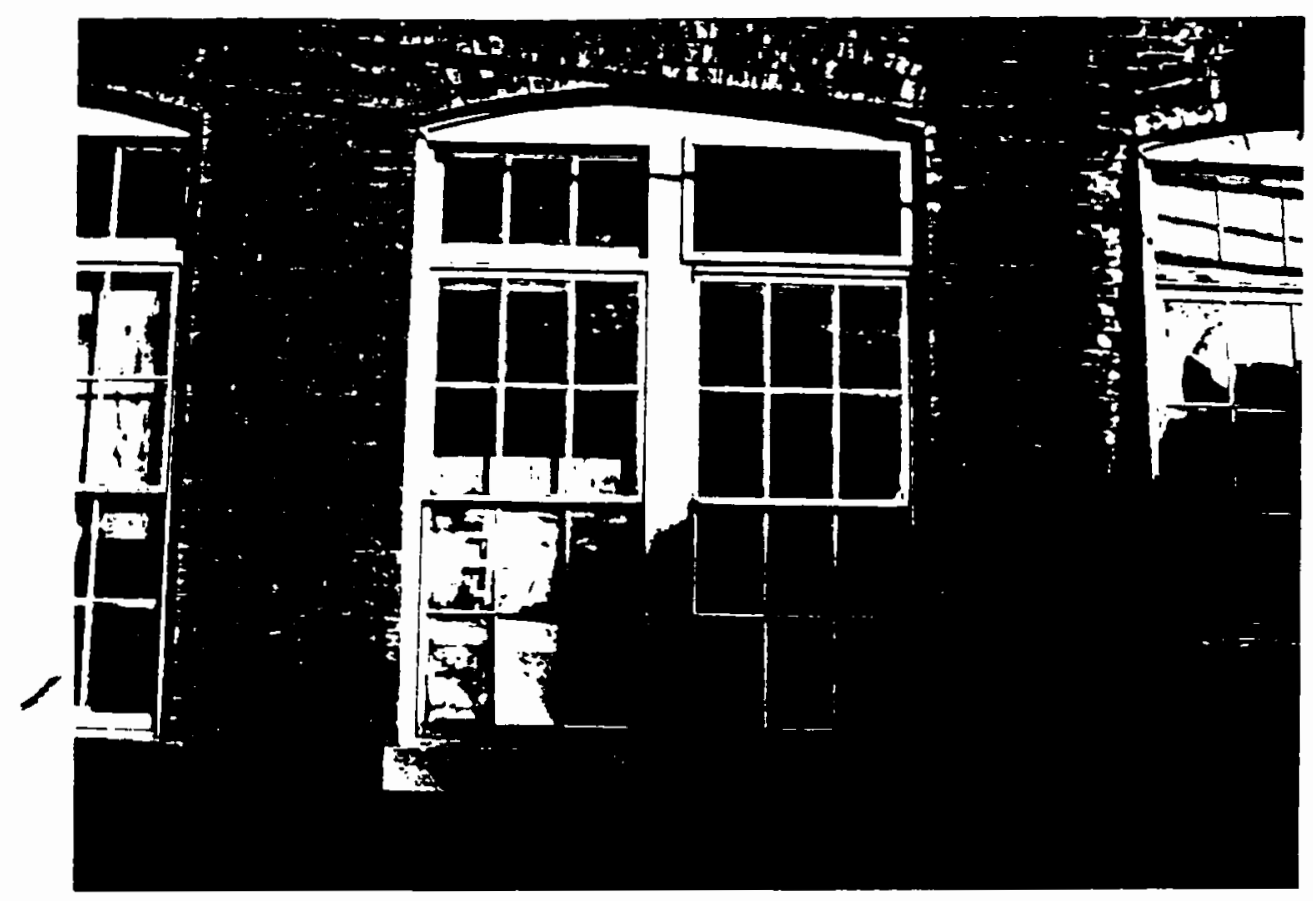

Paired windows with transom

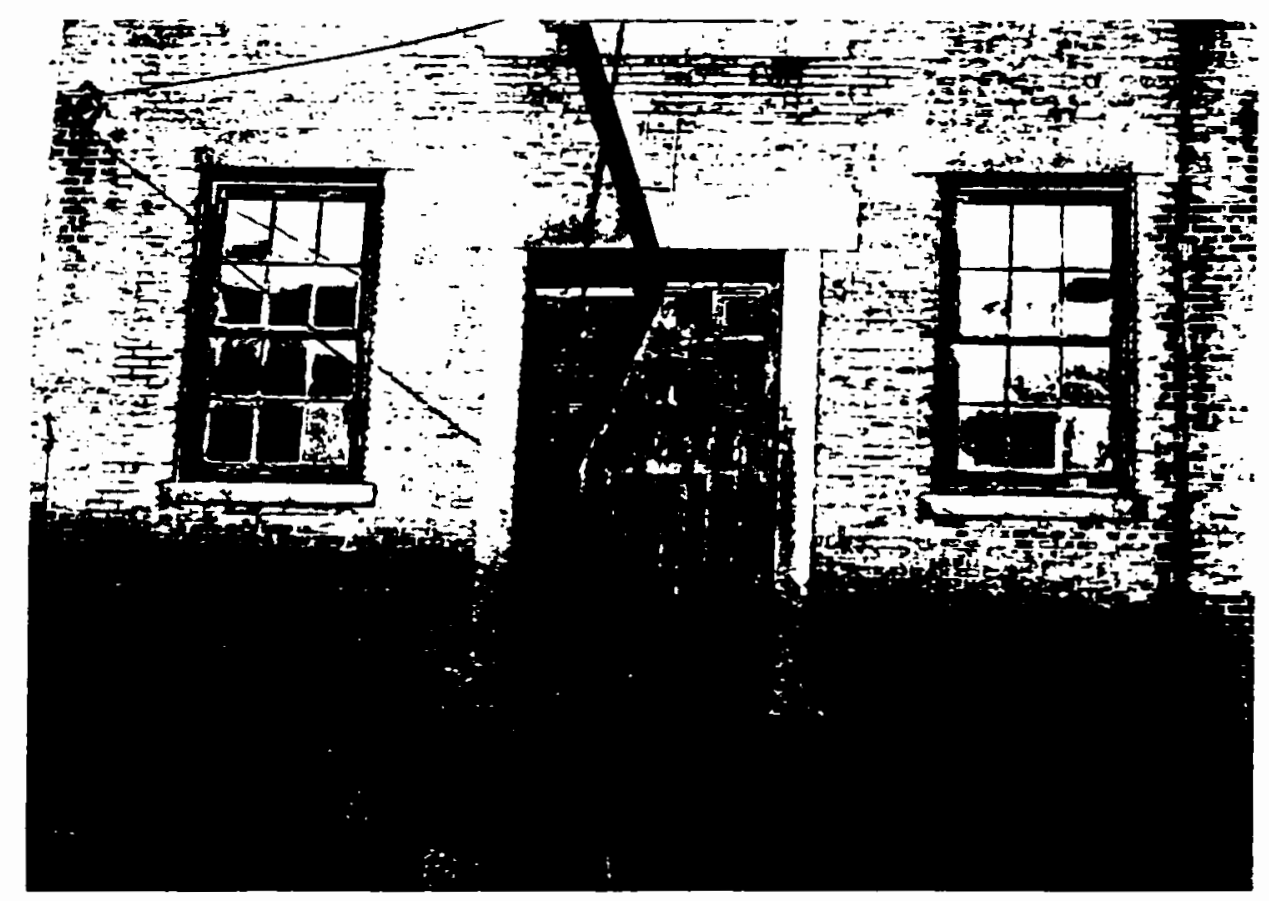

Granite frame opening 


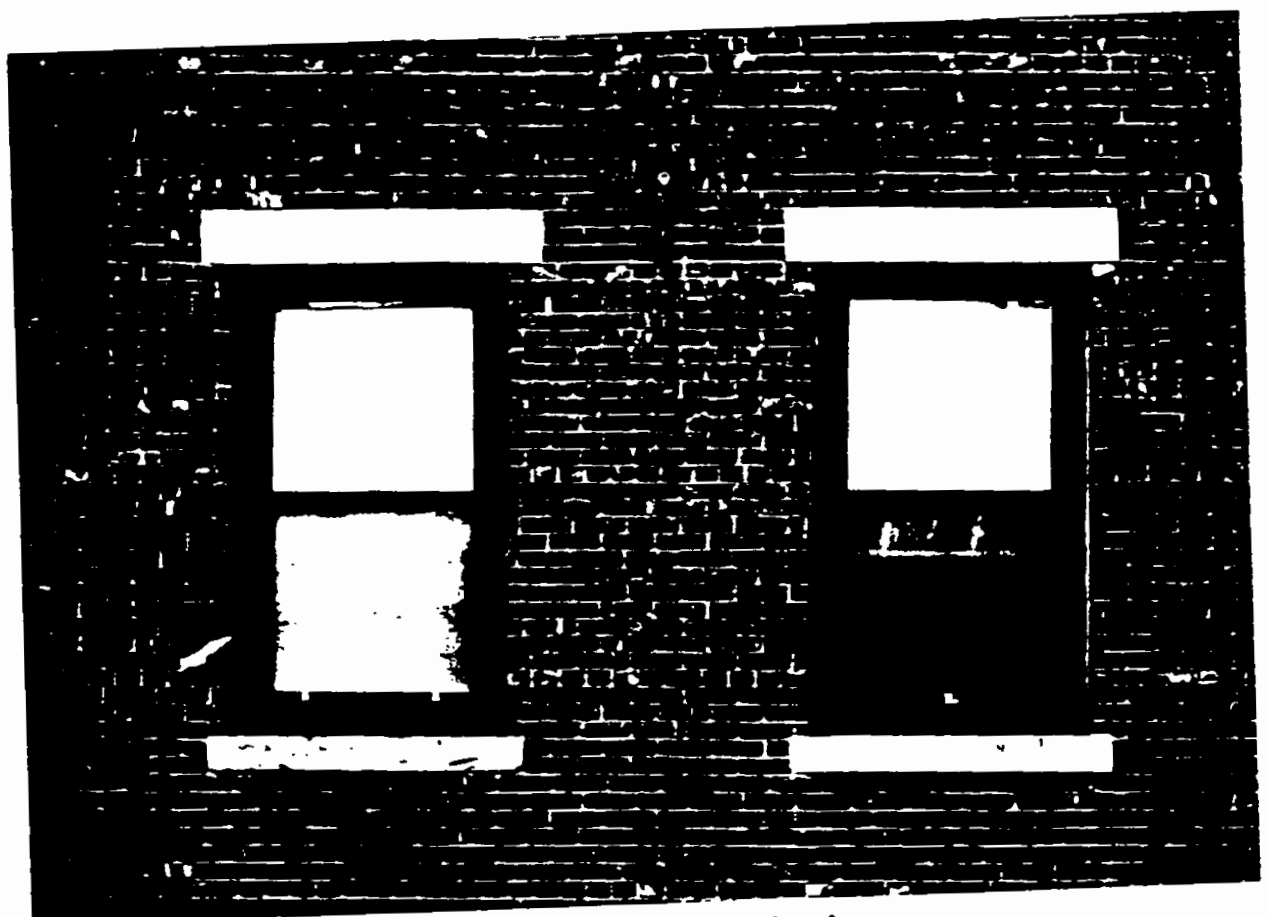

Flat lintel window

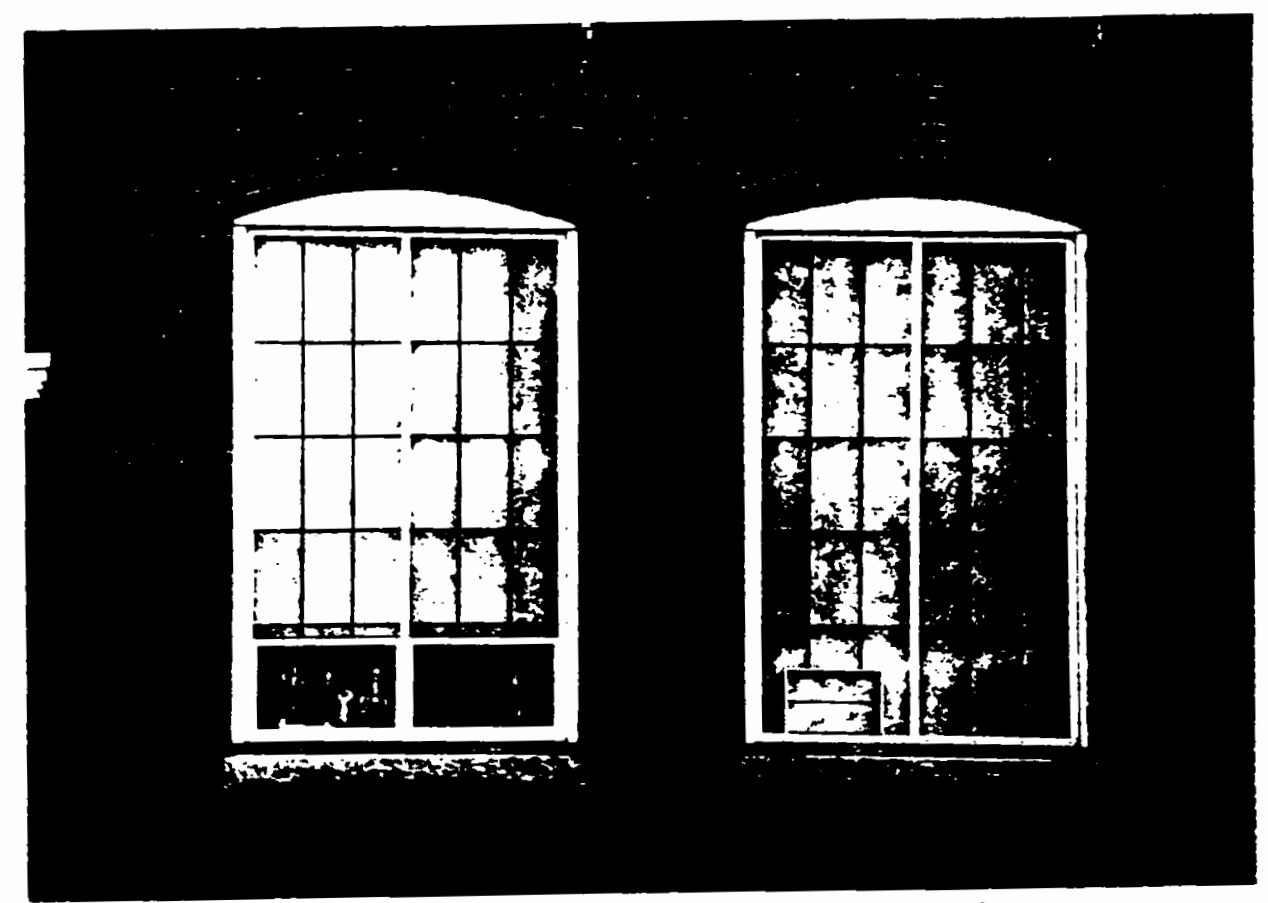

Paired segmental arch window 


\section{Bibliography}

Advisory Council on Historic Preservation. 1988. Supplemental Reader: Introduction to Federal Projects and Historic Preservation Law. Washington, DC: U.S. Government Printing office.

Albert Veri \& Associates, Inc. 1989. Historic Blackstone Riverfront, Master Plan. Providence, RI.

Burchel1, Robert $W$. and David Listokin. 1981. The Adaptive Reuse Handbook. Piscataway, NJ: Center for Urban Policy Research.

Colin, Thomas J. "A Historic Anniversary." Historic Preservation, May 1986, p.25.

Department of Environmental Management. 1990. Lower Blackstone River Re-use Plan, Cumberland and Lincoln, RI. Providence, RI.

Ehrmann, Michael M. 1978. Making Local Rehabilitation Work: Public/Private Relationships. Washington, DC: National Association of Housing and Redevelopment officials.

Goldstein, Joel B. "What Fills an Office Building?" Urban Land, April 1989, pp.2-5.

Heritage Conservation and Recreation Service. 1981. Economics of Revitalization: A Decisionmaking Guide for Local officials. Washington, DC: U.S. Government Printing office.

Heritage Conservation and Recreation Service. 1979. Federal Tax Provisions to encourage Rehabilitation of Historic Buildings: An Assessment of Their Effect. Washington, DC: U.S. Government Printing office.

Heritage Conservation and Recreation Service. 1979. standards for Historic Preservation Projects. Washington, DC: U.S. Government Printing office.

Heritage Conservation and Recreation Service. 1978. Tax Incentives for Rehabilitating Historic Buildings. Washington, DC: U.S. Government Printing office.

Heritage Conservation and Recreation Service. 1978. Rehabilitation: Claremont 1978. Washington, DC: U.S. Government Printing office. 
Kulik, Gary and Julia C. Bonham. 1978. Rhode Island, An Inventory of Historic Engineering and Industrial Sites. washington, DC: U.S. Government Printing office.

Kulik, Gary. Rhode Island Textile Mills, A tour of the Blackstone, Pawtuxet, Moshasshuck and Woonasquatucket River Valleys.

Lawrence Regional/Urban Design Assistance Team. 1990. Lawrence R/UDAT. Lawrence, MA. Pp. 39-47.

Malone, Patrick M. et al. 1984. Industrial Heritage '84, New England Guidebook.

Mancini Bilson, Janet, ed. Central Falls, Rhode Island. In the Wake of the Mills. Rhode Island Community College Profile, Series no. 1 .

Massachusetts Department of Community Affairs. 1977. Built to Last. Washington, DC: Preservation Press.

Meehan, Edmund J. "Elements of Historic Preservation in Selected Center City Areas." (M.C.P research project, University of Rhode Island, 1970).

Preservation Society of Pawtucket. 1990. Pawtucket Mill Building Survey. Providence, Rhode Island: Extrados Architects Ltd.

Reynolds, Douglas M. and Marjory Myers, eds., working in the Blackstone River Valley. 1991. Woonsocket, RI: Sheehan Printing.

Rhode Island Historic Preservation Commission. 1977. Cumberland Preliminary Report. Providence, RI.

Rhode Island Historic Preservation Commission. 1982. Statewide Historic Preservation Report $P-L-1, L i n c o l n, R I$. Providence, RI.

Rhode Island Historic Preservation Commission. 1977. Statewide Historic Preservation Report $P-W-1$, Woonsocket, RI. Providence, RI.

Rhode Island Historic Preservation Commission. 1978. Statewide Historic Preservation Report P-PA-2, Pawtucket, RI. Providence, RI.

Rhode Island Historic Preservation Commission. 1978. Statewide Historic Preservation Report P-CFR-1, Central Falls, RI. Providence, RI. 
Sabnis, Gajanan, ed. 1985. Rehabilitation, Renovation, and Preservation. Detroit: American Concrete Institute.

Save The Bay. "Bring Back the Blackstone," Special Report. Providence, RI.

Slater Mill Historic Site. October 1989. Historic Resources Inventory for the Blackstone River Valley National Heritage Corridor.

Slater Mill Historic Site. 1973. A Photographic Guidebook to the Museum and its collection. Pawtucket, RI: old slater Mill Association.

Thomas, Selma. 1978. Rehabilitation, An Alternative for Historic Industrial Buildings. Washington, DC: U.S. Government Printing office.

Thompson, Elisabeth K. 1977. Recycling Buildings. New York: McGraw Hill, Inc.

United States National Park Service. 1985. Blackstone River Corridor study: Conservation options, Draft. Washington, DC: U.S. Government Printing office.

Woonsocket Parks, Recreation, and Tourism Action Plan, 19881995.

Woonsocket, Rhode Island. 1988. Main Street 2000, The Renaissance, Executive Summary. 


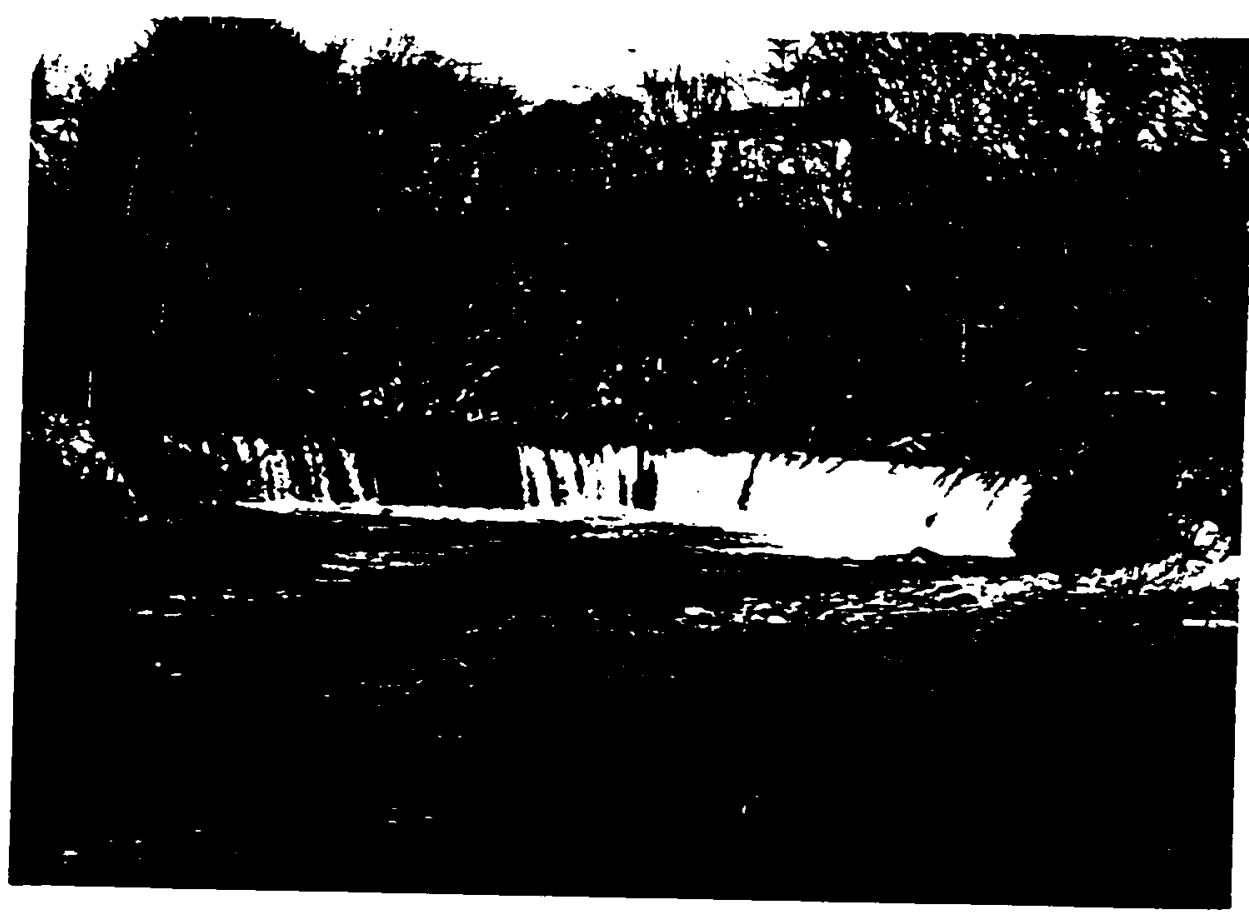

